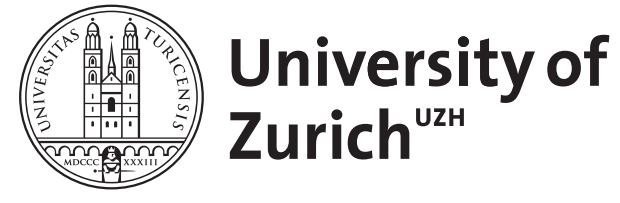

\title{
Serotonin and Schizophrenia
}

Quednow, Boris B ; Geyer, Mark A ; Halberstadt, Adam L

DOI: https://doi.org/10.1016/B978-0-444-64125-0.00039-6

Posted at the Zurich Open Repository and Archive, University of Zurich

ZORA URL: https://doi.org/10.5167/uzh-194870

Book Section

Accepted Version

Originally published at:

Quednow, Boris B; Geyer, Mark A; Halberstadt, Adam L (2020). Serotonin and Schizophrenia. In: Müller, Christian P; Cunningham, Kathryn A. Handbook of the Behavioral Neurobiology of Serotonin 2nd Edition. London: Elsevier, 711-744.

DOI: https://doi.org/10.1016/B978-0-444-64125-0.00039-6 


\title{
Serotonin and Schizophrenia
}

\author{
Boris B. Quednow ${ }^{1}$, Mark A. Geyer ${ }^{2}$, and Adam L. Halberstadt ${ }^{2}$ \\ ${ }^{1)}$ Department of Psychiatry, Psychotherapy and Psychosomatics, \\ Psychiatric Hospital, University of Zurich, Switzerland \\ ${ }^{2)}$ Department of Psychiatry, University of California San Diego, USA

\section{In: The Behavioral Neurobiology of Serotonin $2^{\text {nd }}$ Edition} \\ Editors: Christian R. Müller and Kathryn Cunningham
}

$\begin{array}{ll}\text { Abstract word count: } & 162 \\ \text { Text word count: } & 15^{\prime} 000 \\ \text { Number of tables: } & 3 \\ \text { Number of figures: } & 1\end{array}$

Submission:

Keywords: Serotonin, 5-HT, schizophrenia, model psychosis, LSD, psilocybin, atypical antipsychotics, 5- $\mathrm{HT}_{2 \mathrm{~A}}$ receptor, platelets, positron emission tomography, single nucleotide polymorphism, developmental disorder, dopamine, glutamate, cognition

\section{Corresponding Author:}

Boris B. Quednow, Ph.D., Dipl.-Psych.

Clinical and Experimental Pharmacopsychology

Department of Psychiatry, Psychotherapy and Psychosomatics

Psychiatric Hospital of the University of Zurich

Lenggstrasse 31, CH-8032 Zurich, Switzerland

Tel.: 0041-44-384-2777

Fax: 0041-44-384-3396

E-Mail: quednow@bli.uzh.ch 


\begin{abstract}
Although the serotonin hypothesis of schizophrenia is one of the oldest neurochemical hypotheses on the pathogenesis of the disease, it is still topical. The concept of how the serotonin system is involved in the origin and progress of schizophrenia has changed considerably over the past decades. Therefore, the present chapter gives an overview about the development and the current directions of the serotonin hypothesis of schizophrenia. In this regard, we discuss the phenomenology of hallucinogenic drug action, model psychosis and translational research, post-mortem studies on receptors and transporters, imaging studies, antipsychotic drug action, neuroendocrine challenge studies, platelet and cerebrospinal fluid data, genetic association studies, developmental aspects, and the cross-talk between the glutamate and the serotonin system. In sum, there are several lines of evidence suggesting that the serotonin system plays a role in the pathogenesis of at least a subpopulation of schizophrenia patients. Further studies are still needed to better characterize patients whose psychotic symptoms are suspected to have a serotonergic origin.
\end{abstract}




\section{Introduction}

The symptoms of schizophrenia can be divided into three major domains: (1) positive symptoms such as hallucinations, perceptual disturbances, delusional phenomena, and formal thought disorder; (2) cognitive dysfunction, which includes motivational and executive function deficits; and (3) negative symptoms, including flat affect, poverty of speech, avolition, and inappropriate emotional responses (Tamminga \& Holcomb, 2005). Presentation of symptoms from these three domains is heterogeneous, making the illness difficult to diagnose and treat. The highest risk period for developing schizophrenia is during young adulthood. Both sexes are equally affected by the disorder, although the onset of symptoms typically occurs earlier in men than women (Bromet \& Fennig, 1999; Faraone et al., 1994; Goldstein et al., 1989). Although incidence figures vary depending on the diagnostic criteria, schizophrenia affects approximately $1 \%$ of the general population. Individuals with parents or siblings suffering from schizophrenia have an increased risk for developing the illness (8-12\%). For monozygotic twins, the concordance rate is approximately 50\% (Gottesman, 1991; Holzman \& Matthysse, 1990). The elevated familial incidence of schizophrenia strongly indicates that there is a significant genetic contribution to the disorder, although the fact that concordance rates for monozygotic twins are lower than $100 \%$ suggests that environmental factors are also involved. It is therefore likely that a combination of genetic susceptibility and environmental factors are required for the illness to develop (Gottesman, 1991). Linkage studies of schizophrenia have identified several chromosomal regions and candidate genes that are associated with the disorder (reviewed by Harrison \& Owen, 2003; Harrison \& Weinberger, 2005; for meta-analysis see Ng et al., 2009).

Although there is evidence for enlarged ventricles and decreased cerebral (cortical and hippocampal) volume in schizophrenic patients, there is not a distinct "diagnostic" neuropathology associated with the disease (reviewed by Harrison, 1999b, 2004; Harrison \& Owen, 2003). Misplaced and clustered neurons, particularly in the entorhinal cortex, indicate problems of neuronal migration and suggest an early developmental anomaly (Arnold et al., 1991; Falkai et al., 2000; Jakob \& Beckmann, 1986). Pyramidal neurons in the hippocampus and neocortex have been shown to have smaller cell bodies and fewer dendritic spines and dendritic arborizations (reviewed by Harrison \& Weinberger, 2005). Additionally, decreased levels of presynaptic proteins such as synaptophysin, SNAP-25, and complexin 2 have been observed in the brains of schizophrenia patients (Harrison \& Eastwood, 2001; Honer \& Young, 2004; Osimo et al., 2018) as well as decreased density of interneurons (e.g., parvalbumin-immunoreactive cells; Lewis, 2000; Reynolds et al., 2002). There are also reports of decreases in cell numbers in the thalamus and a decreased number of oligodendrocytes. Neuroimaging data and post-mortem studies have shown that N-acetylaspartate (NAA), a marker of neuronal integrity, is decreased in first-episode and never-medicated patients (Bertolino \& Weinberger, 1999; Nudmamud et al., 2003). Based on these neuropathological changes, investigators have conceptualized schizophrenia as a disease of functional "dysconnectivity" (Friston \& Frith, 1995; McGlashan \& Hoffman, 2000; Weinberger et al., 1992), or a "disorder of the synapse" (Frankle et al., 2003; Mirnics 
et al., 2001) affecting the machinery of neurotransmission (Harrison \& Eastwood, 2001; Honer \& Young, 2004). More recently, the use of magnetic resonance imaging (MRI) technologies confirmed changes is structural and functional connectivity in the brain of schizophrenia patients suggesting that particularly areas of the frontal cortex are disconnected from other brain regions (Canu et al., 2015; Fitzsimmons et al., 2013; Fornito \& Bullmore, 2015).

Not only structural and functional alterations but also neurochemical changes have been proposed to play a role in the etiopathogenesis of schizophrenia. In the following sections we give an overview on the serotonin and dopamine hypothesis of schizophrenia. Although it is one of the oldest neurochemical hypotheses on the pathogenesis of this disease, it is still topical as will be discussed in the following sections.

\section{History of the serotonin hypothesis of schizophrenia}

The first step in the development of the idea that the serotonin system may contribute to schizophrenia was probably done by the German psychiatrist Kurt Beringer (1923). Beringer was the first to propose the use of the hallucinogen mescaline as an experimental model of psychosis, despite the fact that he had neither any knowledge of the existence of serotonin nor of the principles of neurotransmission. Previously, on the eve of the First World War, Knauer and Maloney (1913) recommended mescaline self-experiences to psychiatrists as a way to gain better insight into the psychotic states of their patients. Later, mescaline was found to act as a serotonin-2A $\left(5-\mathrm{HT}_{2 \mathrm{~A}}\right)$ receptor agonist, and played an important role in the development of the transmethylation hypothesis of schizophrenia (see below). In 1943, Albert Hofmann discovered the impressive psychotomimetic effects of d-lysergic acid diethylamide (LSD) during an unintentional self-intoxication in his laboratory at Sandoz (Stoll, 1947). During subsequent self-experiments, Hofmann found that the dose of LSD required to produce psychological effects was remarkably small, strongly suggesting that there must be a receptor or some other specific site of action for the drug. Mescaline, by contrast, had to be given at doses of several hundred milligrams to produce psychotomimetic effects that were comparable to the effects produced by a few micrograms of LSD (Stoll, 1947). Hofmann provided LSD to Walter Stoll, a psychiatrist at the "Burghölzli" - the Psychiatric Hospital of the University of Zurich - and the son of Arthur Stoll, Hofmann's supervisor at Sandoz. Walter Stoll investigated the psychotomimetic effects of LSD in 16 healthy volunteers and found that the effects of LSD were similar to the symptoms of schizophrenia (Stoll, 1947). ${ }^{1}$ Subsequently, both Stoll and his colleague Condrau administered LSD to patients with schizophrenia, hoping that the LSD "shock" would produce some therapeutic benefit. They noted that LSD is much less potent in schizophrenia patients than in normal subjects and therefore proposed that a toxic substance similar to LSD may be responsible for schizophrenic psychoses (Condrau, 1949; Stoll, 1947, 1949). With this observation, they paved the way for the so called transmethylation

\footnotetext{
${ }^{1}$ Interestingly, Stoll (1947) already suggested radioactive labeling of LSD to investigate in animals in which brain regions LSD acts.
} 
hypothesis. Moreover, both of these authors noted that LSD may prove to be a valuable tool to induce psychotic states experimentally in the laboratory.

While searching for a vasoconstrictive substance in platelets, Rapport and colleagues (1948) discovered serotonin and soon thereafter its structure was deduced (Rapport, 1949). Betty Twarog and Irvine Page (1953) subsequently demonstrated that serotonin can be found in the mammalian brain. Initially it was thought that serotonin was simply a constituent of blood in the brain, but the structural similarities between LSD and serotonin led to the suggestion that serotonin may act as a neurotransmitter in the brain (Healy, 2002). Gaddum (1953) quickly determined that the oxytocic effects of serotonin could be antagonized by LSD. As was fashionable at the time among pharmacologists, Gaddum self-administered LSD. The intense experience encouraged him to propose that serotonin in the brain may play a role in preserving sanity (Gaddum \& Hameed, 1954; Healy, 2002). At the same time, Woolley and Shaw (1953) independently discovered that other centrally acting indoleamines (yohimbine, ergot and harmala alkaloids) are also capable of blocking the vasoconstrictive action of serotonin, leading them to also conclude that serotonin may play a role in nervous disorders (Woolley \& Shaw, 1954). Gaddum and Hameed (1954) and Woolley and Shaw (1954) both proposed that the activity of serotonin may be reduced in the brain of schizophrenia patients. Subsequent evidence indicating that LSD acts an agonist rather than an antagonist of serotonin receptors made this hypothesis questionable (Baumeister \& Hawkins, 2004). Later, Woolley (1962) revoked his initial conclusion and suggested instead that schizophrenia may result from an excess of brain serotonin.

Shortly before the discoveries of Gaddum, Woolley and Shaw, another serotonin-related hypothesis of schizophrenia appeared. As early as 1932, Henk de Jong noted that mescaline is chemically related to epinephrine. He therefore raised the possibility that a disturbance of epinephrine metabolism could result in the synthesis of a mescaline-like substance that causes catatonia, one of the primary forms of expression of schizophrenia at that time (de Jong, 1932). Twenty years later, Osmond and Smythies (1952) reinvented this idea and proposed the influential transmethylation hypothesis of schizophrenia. Osmond and Smythies observed that an asthmatic patient developed psychotic symptoms after taking old and therefore oxidized epinephrine during an asthmatic attack. In a self-experiment, Osmond and his director Abram Hoffer then took adrenochrome - a breakdown product of epinephrine with a pink color - and reported that it did, in fact, produce hallucinogenic responses (Healy, 2002). These observations lead to their hypothesis that schizophrenia results from an endogenous neurotoxin that is formed due to aberrant metabolic processes during the biosynthesis of catecholamines. The last step of the biosynthesis of epinephrine is methylation of the amino group of norepinephrine. If the phenolic hydroxyl groups were methylated instead, a mescaline-like compound would be produced. Later Hoffer, Osmond and Smythies (1991) expanded the transmethylation hypothesis by proposing the possibility of an aberrant endogenous biosynthesis of methylated indoleamine hallucinogens such as $N, N$-dimethyltryptamine (DMT). In the following years, many researchers tried to find evidence that 
adrenochrome or another endogenous hallucinogen is present in the brain, blood, and urine of schizophrenia patients. But in the end, it was never convincingly detected. Moreover, Hoffer and Osmond brought their theory directly to the clinic and treated schizophrenia patients with large doses of nicotinic acid, which could potentially reduce the aberrant transmethylation of monoamines by trapping methyl donors. Hoffer and Osmond reported that nicotinic acid, administered alone or in combination with chlorpromazine, had some beneficial effects as a treatment of schizophrenia, but those results could not be replicated in later studies performed by the Canadian Association of Mental Health (Healy, 2002). Although the transmethylation hypothesis still has strong face validity, it fell out of favor after the 1960s for two reasons: first, the putative schizophrenogenic substances could not be isolated, and secondly, a new influential theory involving another neurotransmitter commandeered the focus of schizophrenia research. For the time being, hypotheses based on serotonin were superseded by the influential dopamine hypothesis of schizophrenia.

\section{The dopamine hypothesis of schizophrenia}

Based on the finding of Brodie et al. $(1956 ; 1955)$ that the initial release of serotonin produced by reserpine is followed by a long-lasting depletion of the neurotransmitter, Arvid Carlsson's group demonstrated that reserpine has the same effect on catecholamines (Bertler et al., 1956). These results suggested that serotonin and catecholamines may play a role in the sedative and motor depressant effects of reserpine. Carlsson et al. (1957) tested this hypothesis by administering the neurotransmitter precursors levodopa and 5-hydroxytryptophan to animals pretreated with reserpine. Only levodopa attenuated the behavioral effects of reserpine. Subsequently, it was shown that levodopa administration increases brain dopamine but not norepinephrine (Carlsson, 1959). These results suggested that dopamine likely has an important role in brain function. In 1963, Carlsson and Lindquist reported that chlorpromazine and haloperidol reduced catecholamine activity through a postsynaptic action (Carlsson \& Lindqvist, 1963). Later van Rossum (1966) determined that the behavioral effects of these neuroleptic drugs are mediated blockade of postsynaptic dopamine receptors. Hence, the dopamine hypothesis of schizophrenia - which is actually a hypothesis of antipsychotic drug action - was born. For more than three decades, the dopamine hypothesis has dominated biological research on the etiopathogenesis of schizophrenia. The assumption that schizophrenia is caused by an increase of dopamine function was initially supported by the following data (Bleich et al., 1988):

(1) All antipsychotic drugs act as dopamine- $\mathrm{D}_{2}\left(\mathrm{D}_{2}\right)$ receptor antagonists. Furthermore, prior to the discovery of "atypical" antipsychotics, a significant correlation was found to exist between the typical therapeutic doses of neuroleptics and their $\mathrm{D}_{2}$ receptor binding affinities (Meltzer \& Stahl, 1976; Seeman, 1987). However, the correlation does not extend to clozapine, even though it is one of the most effective antipsychotic drugs (Leucht et al., 2013). In fact, clozapine only has moderate affinity for $\mathrm{D}_{2}$ receptors, and has higher affinity for 5- $\mathrm{HT}_{2 \mathrm{~A}}, 5-\mathrm{HT}_{2} \mathrm{C}, 5-\mathrm{HT}_{6}$ and $5-\mathrm{HT}_{7}$ 
receptors, as well as for $\mathrm{D}_{4}$, histamine $\mathrm{H}_{1}$, muscarinic $\mathrm{M}_{1}$, and adrenergic $\alpha_{1}$ and $\alpha_{2}$ receptors (AbiDargham \& Krystal, 2000; Arnt \& Skarsfeldt, 1998).

(2) Sustained or high-dose exposure to indirect dopamine agonists (e.g., levodopa, cocaine, amphetamine) can cause psychotic symptoms in healthy subjects that are similar to paranoid schizophrenia (Segal et al., 1981). Moreover, indirect dopamine agonists often exacerbate the symptoms of schizophrenia. Amphetamine is known to release presynaptic dopamine and norepinephrine and it was shown that antipsychotics can improve the acute symptoms of amphetamine-induced psychosis (Carlsson, 1988; Snyder, 1973). Nevertheless, the psychotic states caused by indirect dopamine agonists mainly mimic the positive symptoms of schizophrenia; thus, it was suggested that only the positive symptoms of the disorder are linked to increased dopaminergic activity (Angrist \& Gershon, 1970).

(3) Post-mortem studies and positron emission tomography (PET) imaging studies revealed initially that striatal $D_{2}$ receptor levels are increased in the brains of schizophrenia patients (Seeman, 1987; Wong et al., 1986). However, rather than being a pathological abnormality inherent to schizophrenia, the upregulation of $\mathrm{D}_{2}$ receptor expression could occur as an adaptation to chronic of antipsychotic drug treatment; in fact, many post-mortem and PET studies failed to replicate the finding that striatal $D_{2}$ receptor density is increased in drug-naïve schizophrenia patients (Harrison, 1999b; Weinberger \& Laruelle, 2002). However, there is accumulating evidence for an abnormality of presynaptic dopamine function in schizophrenia, implying disturbances in transmitter storage, vesicular transport, release, reuptake, and/or metabolism in the mesolimbic dopamine projection (Laruelle et al., 1999; Weinberger \& Laruelle, 2002; Weinstein et al., 2017).

The current view on the role of dopamine in schizophrenia is that: (1) subcortical mesolimbic dopamine projections may be hyperactive (causing productive/positive symptoms), and (2) the mesocortical dopamine projections to the prefrontal cortex (PFC) and the anterior cingulate cortex are hypoactive (causing negative symptoms and cognitive impairment). These two dysfunctions may be linked as the cortical dopamine system generally inhibits the subcortical dopamine system (Weinberger \& Laruelle, 2002).

Addressing the psychopathological heterogeneity of schizophrenia, Timothy Crow (1980a, 1980b) proposed that schizophrenia can be divided into two syndromes: First, a type I syndrome, characterized by positive symptoms that respond well to antipsychotics and reflect an increase in striatal dopamine function. Second, a type II syndrome that is characterized by negative symptoms, structural brain abnormalities (cortical atrophy and/or ventricular enlargement), and shows only a limited response to typical antipsychotic drugs. Bleich et al. (1988) suggested that the type II syndrome may respond better to compounds acting as serotonin receptor antagonists; therefore, he proposed dopaminergic and serotonergic forms of schizophrenia. This view is supported by the fact 
that certain atypical antipsychotic drugs with potent $5-\mathrm{HT}_{2 \mathrm{~A}}$ receptor antagonistic activity show superior efficacy in the treatment of negative symptoms compared to typical neuroleptics, which produce little or no serotonin receptor blockade (Meltzer, 1999). The fact that amisulpride, a preferential $D_{2} / D_{3}$ antagonist, has a strong impact on both positive and negative symptoms may be explained by its unique pharmacokinetic properties (Leucht, 2004) or by the fact that it also acts as an antagonist at 5- $\mathrm{HT}_{7}$ receptors (Abbas et al., 2009).

\section{Phenomenology of hallucinogenic drug action}

\section{Effects of hallucinogens in human subjects}

Serotonergic hallucinogens produce profound alterations in thought, mood, affect, and sensory perception. The effects of these drugs are often characterized by visual illusions and elementary hallucinations, altered sense of time and space, and depersonalization. Hallucinogen-induced altered states of consciousness (ASCs) are highly subjective and are typically assessed using self-reports. Various rating scales have been used to assess the effects of hallucinogens (reviewed by Strassman, 1995). The Addiction Research Center Inventory (Benneyworth et al., 2007; Haertzen et al., 1963) is an older instrument that emphasized the unpleasant effects of hallucinogens. The Hallucinogen Rating Scale (HRS) was designed specifically to detect the effects of intravenous N,N-dimethyltryptamine (DMT) (Strassman et al., 1994), and has now been validated for other hallucinogens (GouzoulisMayfrank et al., 1999). Another rating scale, the Altered States of Consciousness Questionnaire (APZ), was developed by Dittrich to assess various types of ASCs, independent of their etiology (Dittrich, 1998). The original APZ includes three dimensions: Oceanic Boundlessness (OB), Anxious Ego Dissolution (AED), and Visionary Restructuralization (VR). The OB dimension measures states that resemble mystical experiences, the AED dimension reflects "bad trip"-like experiences, and the VR dimension refers to altered visual perceptions. An updated version of the APZ, the 5D-ASC, includes two additional dimensions: Reduction of Vigilance (RV) and Auditory Alterations (AA). For a detailed description of the APZ and 5D-ASC core dimensions, see Table 1.

Clinical studies have demonstrated that psilocybin, DMT, and mescaline increase scores in the OB, AED, and VR dimensions of the APZ (Dittrich, 1998; Gouzoulis-Mayfrank et al., 1999; Hermle et al., 1992; Vollenweider et al., 1997b). Additional studies have shown that psilocybin produces a dosedependent increase of scores in the five core dimensions of the 5D-ASC rating scale. However, AED and AA scores are only increased significantly after administration of a high dose of psilocybin $(0.315$ $\mathrm{mg} / \mathrm{kg}$, p.o.) and are relatively unaffected by lower doses $(0.045-0.215 \mathrm{mg} / \mathrm{kg})$ (Hasler et al., 2004).

A large amount of preclinical evidence indicates that the $5-\mathrm{HT}_{2 \mathrm{~A}}$ receptor mediates most of the psychedelic and behavioral effects of serotonergic hallucinogens (Nichols, 2004, 2016). For example, pretreatment with the 5- $\mathrm{HT}_{2 \mathrm{~A}}$ antagonist ketanserin blocks the hallucinogenic and cognitive effects of psilocybin in human volunteers (Quednow et al., 2012; Vollenweider et al., 1998), confirming the involvement of the $5-\mathrm{HT}_{2 \mathrm{~A}}$ receptor. According to a PET study with $\left[{ }^{18} \mathrm{~F}\right]$ altanserin, the ability of 
psilocybin to increase 5D-ASC scores is directly correlated with the level of 5- $\mathrm{HT}_{2 \mathrm{~A}}$ receptor occupation in the anterior cingulate cortex (ACC) and medial PFC (Hasler et al., 2009, see Figure 1). These findings are consistent with those of a $\left[{ }^{18} \mathrm{~F}\right]$ fluorodeoxyglucose PET study (Vollenweider et al., 1997b), which found that the effects of psilocybin on the APZ are correlated with increases in PFC and ACC metabolic activity. Several serotonergic hallucinogens also have significant affinity for the 5- $\mathrm{HT}_{1 \mathrm{~A}}$ receptor and other 5-HT receptors (Nichols, 2016; Rickli et al., 2015), which are also likely to contribute to their psychotogenic effects (Halberstadt \& Geyer, 2011).

Table 1. Core dimensions of the 5D-ASC (Dittrich, 1998).

\begin{tabular}{l|l}
\hline Dimension & Symptoms assessed \\
\hline Oceanic Boundlessness (OB) & Positive derealization \\
& Positive depersonalization \\
& Altered sense of time \\
Positive mood & Mania-like experience \\
\hline Anxious Ego Dissolution (AED) & Anxious derealization \\
& Thought disorder \\
& Delusion \\
& Fear of loss of control \\
\hline Visionary Restructuralization (VR) & Elementary hallucinations \\
& Visual pseudohallucinations \\
& Synesthesia \\
& Changed meaning of percepts \\
& Facilitated recollection \\
& Facilitated imagination \\
\hline Auditory Alterations (AA) & Auditory illusions \\
Auditory pseudohallucinations
\end{tabular}




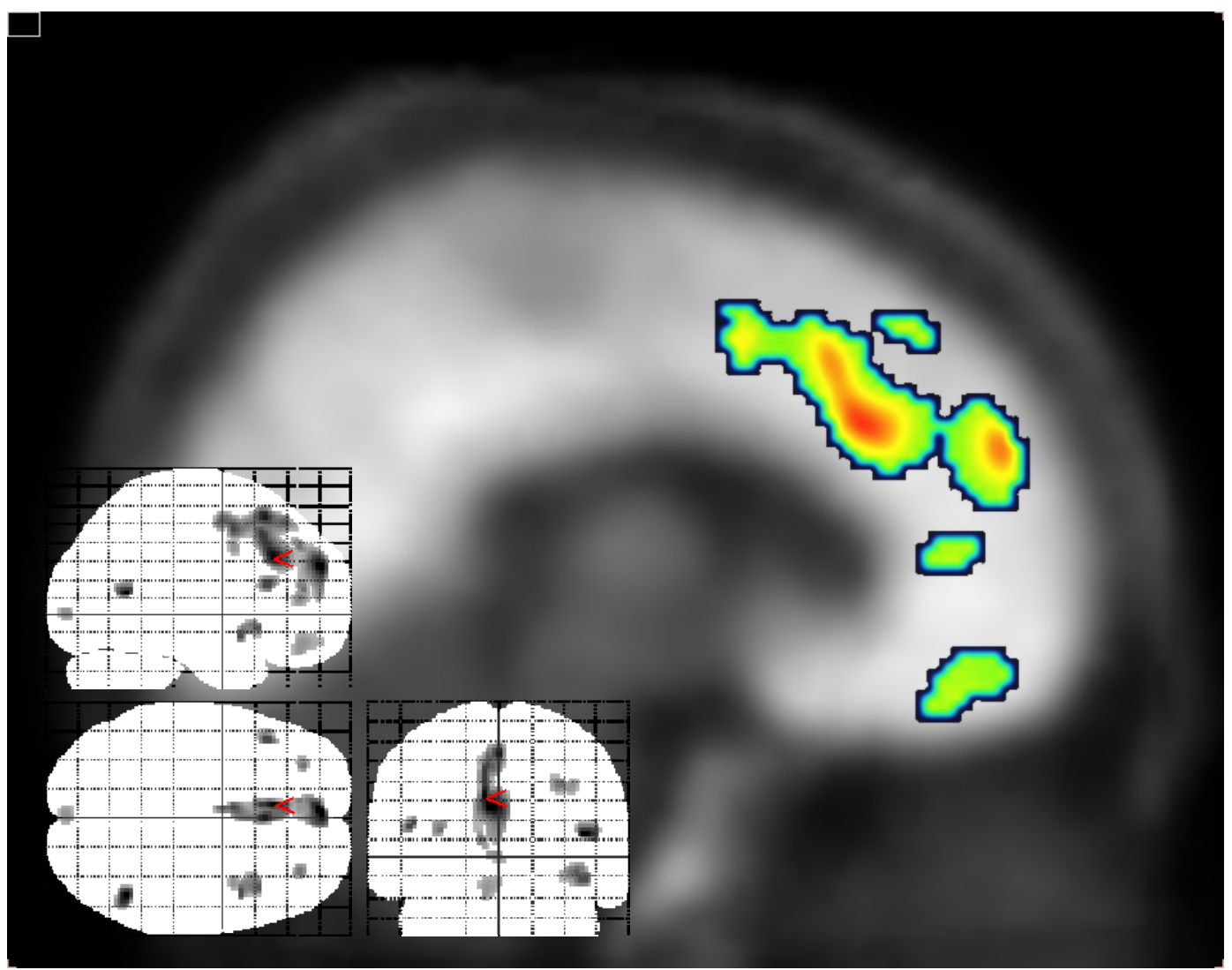

Figure 1: Inverse Correlation of 5D-ASC Global Scale scores and $\left[{ }^{18} F\right]$ altanserin apparent distribution volume [DV']. Results of a voxel based correlation analysis ( $\triangle 5 D$-ASC global vs. $\Delta$ $D V$ ', threshold $p<.005$, uncorrected) using Statistical Parametric Mapping (Hasler et al., 2009).

\section{Comparison of hallucinogen effects and endogenous psychoses}

As noted earlier, Beringer was the first investigator to propose that hallucinogens can be used to produce a "model psychosis" in healthy humans (Beringer, 1923). Subsequent investigations confirmed that administration of mescaline, psilocybin, and LSD induces states that resemble the symptoms of the earliest phases of schizophrenia (Bowers \& Freedman, 1966; Keeler, 1965; Rinkel et al., 1952; Rinkel et al., 1955). Indeed, the loss of control over thought processes that occurs after ingestion of psilocybin (Vollenweider et al., 1997b) closely parallels acute psychotic decompensation (Bowers \& Freedman, 1966; Keeler, 1965). Despite these similarities, Hollister (1962) and other clinicians have argued that there are notable differences between the effects of hallucinogens and the symptomatology of schizophrenia, leading them to question whether hallucinogen-induced psychedelic phenomena is a valid model for endogenous psychotic states. For example, Hollister noted that auditory but not visual hallucinations are prominent in schizophrenia, whereas changes of visual perception are a characteristic effect specifically of serotonergic hallucinogens. However, disturbances in visual perception, including hallucinations and synesthesias, do occur during the acute phase of schizophrenia (Freedman \& Chapman, 1973; McCabe et al., 1972). Hollister (1962) also argued that schizophrenics often display social and emotional withdrawal but this effect is rarely observed after administration serotonergic hallucinogens. There is evidence, however, that administration of 
hallucinogens, especially at high doses, can sometimes induce social withdrawal and states resembling catatonia (Gouzoulis-Mayfrank et al., 1998b).

In a study conducted by Gouzoulis-Mayfrank and colleagues (1998a), the symptoms of schizophrenia were assessed using the APZ rating scale. The goal of that investigation was to determine, using objective criteria, whether psychotic patients experience hallucinogen-like psychedelic effects. The study compared APZ scores from 50 healthy controls and 93 patients with acute schizophrenia, schizophreniform disorder, or schizoaffective disorder. The APZ scores of psychotic patients were found to be significantly higher than those of controls. The study also examined whether the APZ scores correlate with scores on the Brief Psychiatric Rating Scale (BPRS), which measures positive symptoms and general psychopathology. Correlation analysis revealed that the OB subscale of the APZ correlates with BPRS factor 3 (reflecting most of the typical positive symptoms of schizophrenia), whereas the AED subscale correlates with BPRS factor 1 (reflecting anxiety and depression). Amongst others, such findings confirm that patients with acute schizophrenia experience hallucinogen-like effects, indicating that the syndrome induced by hallucinogens is an ecologically valid model of acute schizophrenia (Hermle \& Kraehenmann, 2018).

\section{Animal models of hallucinogen effects relevant to schizophrenia}

In laboratory animals, serotonergic hallucinogens have been shown to 1) potentiate neophobia (Adams \& Geyer, 1982, 1985; Tilson et al., 1975), 2) increase the responsiveness to sensory stimulation (Geyer, 1998; Geyer et al., 1978; Key, 1964), and 3) retard habituation in a variety of input modalities and response output systems (Dulawa \& Geyer, 2000; Geyer \& Moghaddam, 2002; Geyer, 1998; Geyer et al., 1978; Key, 1964). Given the similarities between the psychedelic state induced by hallucinogens and the symptoms of acute schizophrenia, there has been substantial interest in developing animal models of schizophrenia based on the acute behavioral effects of hallucinogens (Geyer \& Vollenweider, 2008). Unfortunately, many of the unconditioned behaviors induced by hallucinogens in animals (e.g., head-twitch response, ear scratch) have no human counterpart, and thus it is not clear how these behaviors relate to the subjective effects of hallucinogens. However, hallucinogens produce effects on habituation and prepulse inhibition (PPI) of startle in animals that are analogous to hallucinogen effects in humans. Based partially on these cross-species similarities, the effects of hallucinogens on habituation and PPI have been proposed as potential behavioral models of schizophrenia (reviewed by Powell \& Geyer, 2007). A brief description of these two behavioral models is provided below.

\section{Habituation}

Repeated presentation of irrelevant stimuli leads to a marked response decrement, a process known as habituation. Habituation is the simplest form of learning, and is necessary for selective attention. Deficits of attention and information-processing are core features of schizophrenia (Braff, 1985; Braff 
\& Geyer, 1990). Patients with schizophrenia are often unable to filter out extraneous stimuli, leading to distractibility, sensory flooding, and impaired cognition (McGhie \& Chapman, 1961). Several studies have found that schizophrenic patients show deficits of startle reflex habituation, potentially contributing to the sensory overload and disorganized cognitive processes that occur in the disorder (e.g., Bolino et al., 1994; Geyer \& Braff, 1982, 1987; Ludewig et al., 2003; Parwani et al., 2000; Quednow et al., 2006). An advantage of using habituation as a behavioral model is that similar testing procedures can be used to assess habituation in experimental animals and humans. For example, LSD and mescaline have been shown to decrease habituation to startling tactile stimuli in rats (Braff \& Geyer, 1980; Geyer et al., 1978), similar to the finding in patients with schizophrenia.

\section{Prepulse inhibition}

The PPI paradigm is often used to assess the loss of sensorimotor gating functions in schizophrenia. PPI refers to the fact that weak pre-stimuli presented at a brief interval $(30-500 \mathrm{~ms})$ prior to a startleeliciting stimulus will reduce, or gate, the amplitude of the resultant startle response. Studies have consistently detected robust PPI deficits in schizophrenia patients (e.g., Bolino et al., 1994; Braff \& Geyer, 1990; Braff et al., 1978; Ludewig et al., 2003; Parwani et al., 2000; Quednow et al., 2008a; Quednow et al., 2006). It was proposed that the mechanism underlying PPI regulates sensory input by filtering out irrelevant or distracting stimuli in order to prevent sensory information overflow and to allow for selective and efficient processing of relevant information (Swerdlow \& Geyer, 1998). The consistently reported PPI deficits in schizophrenia patients contributed to the view that schizophrenia could be seen as a disorder of deficient gating or filtering (Carlsson, 1995). As detailed in the previous chapter of Halberstadt and Nichols, hallucinogens such as LSD and 2,5-dimethoxy-4iodoamphetamine (DOI) also disrupt PPI. Thus, the hallucinogen-treated animals tested in the PPI paradigm exhibit an increased or unfiltered responsiveness to sensory stimuli. That is, they fail to show the gating or inhibition of the response normally induced by the prepulse. As reviewed elsewhere (Geyer et al., 2001; Swerdlow et al., 2001), the cross-species phenomenon of PPI is very robust, unlearned, and ubiquitous. Indeed, depending on the testing parameters used, the hallucinogen psilocybin has been shown to produce PPI deficits in normal human volunteers (Quednow et al., 2012; Vollenweider et al., 2007). Hence, the ability of hallucinogens to alter PPI has been considered to be a useful model of the positive symptoms of schizophrenia.

\section{Serotonin receptor and transporter changes in vivo and postmortem in schizophrenia}

Early postmortem studies with schizophrenia patients revealed that 5-HT and 5-hydroxyindoleacetic acid (5-HIAA) levels are increased in subcortical brain regions such as the putamen, nucleus accumbens, and globus pallidus (Crow et al., 1979; Farley et al., 1980), whereas 5-HIAA levels are decreased in cortical regions including cingulate and frontal areas (Winblad et al., 1979). Many subsequent studies investigated altered serotonin receptor and transporter expression in schizophrenia 
patients, both in vivo and post-mortem, often using radiolabeled compounds. Most of these receptor investigations explored the density of $5-\mathrm{HT}_{1 \mathrm{~A}}$ or $5-\mathrm{HT}_{2 \mathrm{~A}}$ receptors, often with highly divergent results.

\section{5-HT $T_{1 A}$ receptors}

One of the most consistent alterations of 5-HT parameters observed in schizophrenia patients is the increase in the density of $5-\mathrm{HT}_{1 \mathrm{~A}}$ receptors in the $\mathrm{PFC}$, which was identified in postmortem studies (Bantick et al., 2001; Weinberger \& Laruelle, 2002). Seven of ten studies (conducted using either $\left.{ }^{3} \mathrm{H}\right] 8-\mathrm{OH}-\mathrm{DPAT}$ or the more specific compound $\left[{ }^{3} \mathrm{H}\right]$ WAY-100653 to label 5-HT $\mathrm{HA}_{1 \mathrm{~A}}$ receptors, or by analysis of $5-\mathrm{HT}_{1 \mathrm{~A}}$ receptor mRNA expression in cortical tissue) have reported a $15-80 \%$ increase in receptor levels in the dorsolateral or orbital PFC, whereas other brain regions such as the ACC and the temporal cortex showed less consistent results, including possible increases (for review and citations see Bantick et al., 2001; and Gray et al., 2006). A meta-analysis including eight of these studies confirmed a significant elevation of prefrontal $5-\mathrm{HT}_{1 \mathrm{~A}}$ receptors with a moderate to large effect size (Selvaraj et al., 2014). Interestingly, the increase in prefrontal 5- $\mathrm{HT}_{1 \mathrm{~A}}$ receptor density was not necessarily accompanied by a change in the expression of $5-\mathrm{HT}_{1 \mathrm{~A}}$ receptor mRNA (Burnet et al., 1996b). Moreover, the only study that stained for 5- $\mathrm{HT}_{1 \mathrm{~A}}$-like immunoreactivity did not detect any differences between schizophrenia patients and controls (Cruz et al., 2004). Since receptors located at other cellular locations could not be visualized with the antibody used, changes in the overall density of 5- $\mathrm{HT}_{1 \mathrm{~A}}$ receptor expression could not be excluded by this study. Finally, a study investigating 5$\mathrm{HT}_{1 \mathrm{~A}}$ receptor mRNA abundance in the dorsal raphe nucleus did not find any differences in schizophrenia patients compared to controls (Matthews \& Harrison, 2012).

In contrast to the consistent cortical findings in postmortem studies, the results of recent investigations of 5-HT ${ }_{1 \mathrm{~A}}$ receptor distribution using $\left[{ }^{11} \mathrm{C}\right] \mathrm{WAY}-100653$ or $\left[{ }^{18} \mathrm{~F}\right] \mathrm{MPPF}$ PET in schizophrenia patients have been contradictory. One study reported increased binding only in the medial temporal lobe (Tauscher et al., 2002), two studies observed decreased binding in the amygdala (Yasuno et al., 2004) and in the frontal and orbitofrontal cortices (Lerond et al., 2013), whereas two other studies found no alterations in cortical 5- $\mathrm{HT}_{1 \mathrm{~A}}$ receptor binding (Bantick et al., 2004; Frankle et al., 2006). Moreover, Bantick et al. (2004) found no differences in 5- $\mathrm{HT}_{1 \mathrm{~A}}$ receptor binding between clozapine-treated patients, patients medicated with antipsychotics with low 5- $\mathrm{HT}_{1 \mathrm{~A}}$ affinity, and healthy human volunteers. The authors concluded that clozapine did not occupy $5-\mathrm{HT}_{1 \mathrm{~A}}$ receptors at clinicallyrelevant doses. With respect to the inconsistencies between PET and postmortem studies, Frankle et al. (2006) suggested that the alterations found in postmortem studies cannot be reliably detected in PET studies, which puts into question whether $5-\mathrm{HT}_{1 \mathrm{~A}}$ receptors play a major role in the pathophysiology of schizophrenia. Due to the fact that schizophrenia patients included in postmortem studies are rarely antipsychotic-naïve, whereas PET studies have mostly assessed drug-naïve or unmedicated patients, it is likely that the $5-\mathrm{HT}_{1 \mathrm{~A}}$ receptor changes found in the majority of post-mortem studies are probably 
the result of chronic medication with antipsychotics or other psychotropics. However, in two of the postmortem studies, 5- $\mathrm{HT}_{1 \mathrm{~A}}$ receptor increases were also observed in drug-free patients (Hashimoto et al., 1991; Sumiyoshi et al., 1996).

In sum, findings with respect to $5-\mathrm{HT}_{1 \mathrm{~A}}$ receptor changes are highly contradictory. Postmortem studies consistently indicate an increase of 5- $\mathrm{HT}_{1 \mathrm{~A}}$ receptor expression - especially in the $\mathrm{PFC}$ - whereas PET studies did not find changes in PFC receptor binding. Effects due to chronic treatment with antipsychotic medication may contribute to these divergent results. When schizophrenia patients actually display frontal upregulation of $5-\mathrm{HT}_{1 \mathrm{~A}}$ receptors, this effect may reflect glutamatergic network abnormalities because in the neocortex these receptors are mainly located on pyramidal cells (Bantick et al., 2001).

\section{5-HT $T_{2 A}$ receptors}

Of all the 5-HT receptors examined in postmortem schizophrenia studies over the last 30 years, the 5$\mathrm{HT}_{2 \mathrm{~A}}$ receptor has been the most intensively investigated. Fifteen out of nineteen postmortem studies reported decreased 5- $\mathrm{HT}_{2 \mathrm{~A}}$ receptor binding-densities (or decreased levels of 5- $\mathrm{HT}_{2 \mathrm{~A}}$ receptor mRNA expression) in cortical areas - especially in the frontal cortex - of schizophrenia patients (for references and details see Table 2). Two of the studies reported an increase in multiple brain regions, whereas the two remaining studies did not find 5- $\mathrm{HT}_{2 \mathrm{~A}}$ receptor changes. Moreover, only five investigations explored $5-\mathrm{HT}_{2 \mathrm{~A}}$ receptors in the basal ganglia, and only one report suggested increased $5-\mathrm{HT}_{2 \mathrm{~A}}$ levels, whereas the other four studies found no changes. In addition, a meta-analysis including eight of those studies demonstrated a significant reduction of $5-\mathrm{HT}_{2 \mathrm{~A}}$ receptor levels, with an especially large effect size in PFC (Selvaraj et al., 2014). It should be noted that although the radioligands used in those studies have high-affinity for 5- $\mathrm{HT}_{2 \mathrm{~A}}$ receptors, they also label other receptor subtypes. For example, ketanserin also labels $\alpha$-adrenoceptors, histamine $\mathrm{H}_{1}$ receptors, and the vesicular monoamine transporter; LSD also binds to $5-\mathrm{HT}_{1 \mathrm{~A}}, 5-\mathrm{HT}_{1 \mathrm{E}}, 5-\mathrm{HT}_{2 \mathrm{C}}, 5-\mathrm{HT}_{6}, 5-\mathrm{HT}_{7}$, and dopamine- $\mathrm{D}_{2}$ receptors; and spiperone also has high affinity for $\mathrm{D}_{2}$ receptors (Harrison, 1999a). The lack of specificity of these radioligands must be taken into account when these studies are interpreted. However, gene expression studies using in situ hybridization or transcriptome sequencing have also confirmed reduced expression of the 5- $\mathrm{HT}_{2 \mathrm{~A}}$ receptor gene in the frontal cortex of schizophrenia patients (Cheah et al., 2017; Hernandez \& Sokolov, 2000). Interestingly, Cheah et al (2017), additionally investigated methylation of the $5-\mathrm{HT}_{2 \mathrm{~A}}$ gene and showed that three $\mathrm{CpG}$ binding sites were hypermethylated in schizophrenia patients, indicating that epigenetic changes of 5- $\mathrm{HT}_{2 \mathrm{~A}}$ receptor expression may contribute to the development of schizophrenia (see also Abdolmaleky et al., 2011).

Legitimately, the question has been raised regarding whether these receptor expression changes are simply the result of chronic drug treatment, because most of the patients studied were treated with antipsychotic drugs for many years. Indeed, it was shown that long-term treatment with clozapine decreases $5-\mathrm{HT}_{2 \mathrm{~A}}$ receptor binding and mRNA expression in the cingulate and frontal cortices of rats. 
In contrast, haloperidol did not alter cortical $5-\mathrm{HT}_{2 \mathrm{~A}}$ receptor density or expression in the frontal cortex of rats (Burnet et al., 1996a; O'Dell et al., 1990; Reynolds et al., 1983a; Wilmot \& Szczepanik, 1989). Other atypical antipsychotics that are $5-\mathrm{HT}_{2 \mathrm{~A}}$ antagonists may also reduce cortical $5-\mathrm{HT}_{2 \mathrm{~A}}$ receptors when given chronically (Andree et al., 1986; Mikuni \& Meltzer, 1984; Padin et al., 2006). However, only a very small number of patients were treated with clozapine or other atypical substances, particularly in earlier studies. Additionally, antipsychotic medication may increase rather than decrease 5- $\mathrm{HT}_{2 \mathrm{~A}}$ receptor expression (Hernandez \& Sokolov, 2000), and many studies also found decreased $5-\mathrm{HT}_{2 \mathrm{~A}}$ receptor densities in unmedicated subjects, or did not detect dose-effects of previous antipsychotic drug treatment (see Table 2). Thus, the decrease of 5- $\mathrm{HT}_{2 \mathrm{~A}}$ receptors, especially in the dorsolateral PFC, could not be explained solely by chronic drug treatment; more likely, a pathological process probably also has to be involved (Dean, 2003). 
Table 2: Postmortem studies investigating 5-HT2A receptor density in schizophrenia (modified and updated according to Harrison, 1999a).

\begin{tabular}{|c|c|c|c|c|c|}
\hline Study & Method $^{1}$ & Brain region $^{2}$ & Cases/controls & Medicated cases & Main findings \\
\hline \multicolumn{6}{|l|}{ Decrease in cortical binding } \\
\hline Bennett et al. (1979) & HB with $\left[{ }^{3} \mathrm{H}\right] \mathrm{LSD}$ & BA $6,8-11,44-47$ & $26 / 25^{3}$ & 18 & $\downarrow 40-50 \%$, no effect of medication \\
\hline Mita et al. (1986) & HB with $\left[{ }^{3} \mathrm{H}\right]$ ketanserin & BA 9 & $11 / 9$ & 7 & $\downarrow 36 \%$, no effect of medication \\
\hline Arora \& Meltzer (1991) & HB with $\left[{ }^{3} \mathrm{H}\right]$ spiperone & BA $8 / 9$ & $11 / 11$ & 11 & $\downarrow 33 \%$, no effect of medication \\
\hline Laruelle et al. (1993a) & HB with $\left[{ }^{3} \mathrm{H}\right]$ ketanserin & BA $10,17 / 18$ & $10 / 12^{4}$ & 6 & $\downarrow 21 \%$ in BA 10 , no effect of medication \\
\hline Burnet et al. (1996b) & a) RA with $\left[{ }^{3} \mathrm{H}\right]$ ketanserin & BA $17,22,46$, MTL, AC & $13 / 15$ & 12 & $\downarrow 27 \%$ in BA $46, \downarrow 38 \%$ MTL, similar trend in AC \\
\hline & b) mRNA using ISH & & & & $\downarrow 49-63 \%$ in BA $17,22,46, \mathrm{AC}, \leftrightarrow$ in MTL \\
\hline Dean \& Hayes (1996) & RA with $\left[{ }^{3} \mathrm{H}\right]$ ketanserin & BA $8,9,10$ & $20 / 20$ & 19 & $\downarrow 25-33 \%$ in all frontal regions \\
\hline Gurevich \& Joyce (1997) & RA with $\left[{ }^{125} \mathrm{I}\right] \mathrm{LSD}$ & $\begin{array}{l}\mathrm{BA} 1-3,4,6,8,9,31,32,40,44- \\
46, \mathrm{AC}, \mathrm{PC}\end{array}$ & $10 / 12$ & 5 & $\begin{array}{l}\downarrow \sim 60 \% \text { in BA } 6,24 \text { in drug-free cases, } \downarrow \sim 70-90 \% \text { in } \\
\text { all brain regions in medicated cases }\end{array}$ \\
\hline Kouzmenko et al. (1997) & RA with $\left[{ }^{3} \mathrm{H}\right]$ ketanserin & BA $9 / 46$ & $63 / 62^{5}$ & 60 & $\downarrow 33 \%$ \\
\hline Dean et al. (1998) & RA with $\left[{ }^{3} \mathrm{H}\right]$ ketanserin & BA 9 & $55 / 55$ & 55 & $\downarrow 33 \%$ \\
\hline Dean et al. (1999a) & RA with $\left[{ }^{3} \mathrm{H}\right]$ ketanserin & BA 9 & $19 / 19$ & 17 & $\downarrow 35 \%$ \\
\hline Hernandez \& Sokolov (2000) & mRNA using ISH & BA 9 & $21 / 14$ & 18 & $\begin{array}{l}\downarrow 60 \% \text { in patients that were drug free for }>26 \text { weeks, } \\
\text { antipsychotic treatment increased } 5-\mathrm{HT}_{2 \mathrm{~A}} \text { mRNA }\end{array}$ \\
\hline \multirow[t]{2}{*}{ Pralong et al. (2000) } & a) RA with $\left[{ }^{3} \mathrm{H}\right]$ ketanserin & BA 22 (planum temporale) & $20 / 20$ & 17 & $\downarrow 32 \%$ \\
\hline & b) HB with $\left[{ }^{3} \mathrm{H}\right]$ ketanserin & BA 22 (planum temporale) & $10 / 10$ & 10 & $\begin{array}{l}\downarrow 34 \% B_{\max } \uparrow 119 \% \text {, changes in affinity }\left(K_{\mathrm{d}}\right) \text { but not } \\
\text { density }\left(B_{\max }\right) \text { explained by medication effects }\end{array}$ \\
\hline Scarr et al. (2004) & RA with $\left[{ }^{3} \mathrm{H}\right]$ ketanserin & MTL (only hippocampus) & $20 / 20$ & 20 & $\downarrow \sim 29-47 \%$ across different hippocampal regions \\
\hline Matsumoto et al. (2005) & RA with $\left[{ }^{3} \mathrm{H}\right]$ ketanserin & BA 9, MTL & $6 / 6$ & 6 & $\downarrow 39 \%$ in BA $9, \leftrightarrow$ in MTL \\
\hline Cheah et al. (2017) & mRNA using TS & BA 10 or 46 & $25 / 25$ & 23 & $\downarrow 14 \%$ \\
\hline \multicolumn{6}{|l|}{ Increase in cortical binding } \\
\hline Whitaker et al. (1981) & HB with $\left[{ }^{3} \mathrm{H}\right] \mathrm{LSD}$ & BA $4,10,11$ & $13 / 8$ & 8 & $\leftrightarrow, \uparrow 55 \%$ in unmedicated cases \\
\hline Joyce et al. (1993) & RA with $\left[{ }^{125} \mathrm{I}\right] \mathrm{LSD}$ & BA $4,9,21$, AC, PC, MTL & $8 / 10$ & 4 & $\uparrow \sim 50-100 \%$ only in MTL, BA 21, PC \\
\hline
\end{tabular}




\begin{tabular}{|c|c|c|c|c|c|}
\hline Reynolds et al. (1983b) & HB with $\left[{ }^{3} \mathrm{H}\right]$ ketanserin & BA 10 & $11 / 10$ & 11 & $\leftrightarrow$ \\
\hline Dean et al. (1996) & HB with $\left[{ }^{3} \mathrm{H}\right]$ ketanserin & BA 9 & $20 / 20$ & 19 & $\leftrightarrow$ \\
\hline \multicolumn{6}{|l|}{ Increase in basal ganglia } \\
\hline Joyce et al. (1993) & RA with $\left[{ }^{3} \mathrm{H}\right]$ ketanserin & Caudate, putamen, NAC & $8 / 10$ & 4 & $\uparrow \sim 30-75 \%$ \\
\hline \multicolumn{6}{|l|}{ No changes in basal ganglia } \\
\hline Mackay et al. (1978) & HB with $\left[{ }^{3} \mathrm{H}\right]$ spiperone & NAC & $26 / 17$ & $?$ & $\leftrightarrow$ \\
\hline Owen et al. (1981) & HB with $\left[{ }^{3} \mathrm{H}\right] \mathrm{LSD},\left[{ }^{3} \mathrm{H}\right] 5-\mathrm{HT}$ & Caudate, putamen & $19 / 20$ & $? 12$ & $\leftrightarrow$ \\
\hline Seeman et al. (1993) & HB with $\left[{ }^{3} \mathrm{H}\right]$ ketanserin & Striatum & $9 / 4$ & 6 & $\leftrightarrow$ \\
\hline Matsumoto et al. (2005) & RA with $\left[{ }^{3} \mathrm{H}\right]$ ketanserin & Caudate, putamen & $6 / 6$ & 6 & Not significant but strong trend for decrease $(\downarrow 34 \%)$ \\
\hline
\end{tabular}

1. $H B=$ homogenate binding; ISH = in situ hybridization; $R A=$ receptor autoradiography; $T S=$ transcriptome sequencing.

2. $B A=$ Brodmann area; $B A 4=$ motor cortex; $B A 6,8,9,10,11,44-47=$ prefrontal cortex; $B A 17 / 18=$ occipital cortex; $B A$ 21, $22=$ temporal cortex, $A C=$ anterior cingulate cortex; $P C=$ posterior cingulate cortex; $M T L=$ mediotemporal lobe including hippocampus, amygdale, uncus, parahippocampal gyrus, entorhinal cortex; NAC = Nucleus accumbens.

3. Sum of three separate case control groups. The decrease in $\left[^{3} H\right] L S D$ binding was demonstrated in all three comparisons.

4. Includes six subjects with schizoaffective disorder. Significant differences remained when these subjects were excluded.

5. Included cases of Burnet et al. (1996b) and Dean \& Hayes (1996). 
PET studies administering 5- $\mathrm{HT}_{2 \mathrm{~A}}$ receptor tracers to schizophrenia patients show inconsistent results. Three studies using $\left[{ }^{18} \mathrm{~F}\right]$ septoperone and one study using $\left[{ }^{11} \mathrm{C}\right] N$-methylspiperone did not show any significant differences in 5- $\mathrm{HT}_{2 \mathrm{~A}}$ receptor densities between schizophrenia patients and controls, using both region-of-interest (ROI)- and voxel-based analyses (Lewis et al., 1999; Okubo et al., 2000; Trichard et al., 1998; Verhoeff et al., 2000). However, both tracers suffer from a relatively low affinity for $5-\mathrm{HT}_{2 \mathrm{~A}}$ receptors and therefore they have an insufficient signal-to-noise ratio in subcortical areas (Erritzoe et al., 2008). In contrast, two studies performed with $\left[{ }^{18} \mathrm{~F}\right]$ septoperone and the more selective $5-\mathrm{HT}_{2 \mathrm{~A}}$ antagonist $\left[{ }^{18} \mathrm{~F}\right]$ altanserin found decreased frontal $5-\mathrm{HT}_{2 \mathrm{~A}}$ receptor densities in antipsychoticnaïve schizophrenia patients (Ngan et al., 2000: -16.3\%; Rasmussen et al., 2010: -13.6\%), while another $\left[{ }^{18} \mathrm{~F}\right]$ altanserin study in a similar patient sample failed to demonstrate a frontal $5-\mathrm{HT}_{2 \mathrm{~A}}$ receptor decrease but did find an increase in the caudate (Erritzoe et al., 2008). Two further studies used $\left[{ }^{18} \mathrm{~F}\right]$ altanserin $\mathrm{PET}$ to investigate $5-\mathrm{HT}_{2 \mathrm{~A}}$ receptor density in subjects supposed to be in the prodromal phase of schizophrenia and reported decreased binding of the radiotracer in the PFC (Hurlemann et al., 2005; 2008). In the later study, Hurlemann et al. (2008) additionally detected decreased $5-\mathrm{HT}_{2 \mathrm{~A}}$ receptor binding in the right insular cortex, left amygdala, bilateral hippocampi, right caudate, and the left putamen in medication-naive subjects in a late prodromal stage. Interestingly, the presence of a low $5-\mathrm{HT}_{2 \mathrm{~A}}$ receptor density in the right caudate predicted later conversion to full-blown psychosis, a finding that is highly discrepant with the results of Errizoe et al. (2008). Finally, an interesting $\left[{ }^{18} \mathrm{~F}\right]$ altanserin PET study with monocygotic twins discordant for schizophrenia revealed strongly reduced (33\%) frontal $5-\mathrm{HT}_{2 \mathrm{~A}}$ receptor binding in the twin with schizophrenia relative to the healthy twin (Rasmussen et al., 2016). Taken together, in contrast to the high consistency of the postmortem findings, the PET results are more contradictory, but also point to a reduction in frontal $5-\mathrm{HT}_{2 \mathrm{~A}}$ receptor density in schizophrenia. However, given that the methodological differences between the PET studies are not really obvious, further studies are needed to clarify whether $5-\mathrm{HT}_{2 \mathrm{~A}}$ receptor changes can also be detected using an in vivo imaging approach. The new and highly selective $5-\mathrm{HT}_{2 \mathrm{~A}}$ receptor radioligand $\left[{ }^{11} \mathrm{C}\right] \mathrm{MDL} 100,907$ may be a promising tool to further investigate alterations in $5-\mathrm{HT}_{2 \mathrm{~A}}$ receptor expression in schizophrenia (Ito et al., 1998).

\section{Other serotonin receptors}

Other serotonin receptor subtypes have been investigated in postmortem schizophrenia studies: Two studies using $\left[{ }^{3} \mathrm{H}\right] \mathrm{GR} 113808$ autoradiography have shown that the density of $5-\mathrm{HT}_{4}$ receptors is unaltered in either the dorsolateral PFC or the hippocampus of deceased schizophrenia patients (Dean et al., 1999b; Scarr et al., 2004). A postmortem study using $\left[{ }^{3} \mathrm{H}\right] \mathrm{LY} 278584$ autoradiography to investigate the density of 5- $\mathrm{HT}_{3}$ receptors (the only ion-channel in the 5-HT receptor family) in the amygdala of schizophrenia patients and controls with did not find any group differences (AbiDargham et al., 1993). The density of the $5-\mathrm{HT}_{6}$ receptor in the frontal cortex, measured with $\left[{ }^{125} \mathrm{I}\right] \mathrm{SB}-$ 258585, was not changed in 20 schizophrenia patients compared to 17 control subjects (East et al., 
2002). Recently, two studies investigated the densities of $5-\mathrm{HT}_{1 \mathrm{D}}$ and $5-\mathrm{HT}_{1 \mathrm{~F}}$ receptors in the dorsolateral PFC and the hippocampus, respectively, of schizophrenia patients using $\left[{ }^{3} \mathrm{H}\right]$ sumatriptan autoradiography (Dean et al., 2006; Scarr et al., 2004). While Scarr et al. reported a decrease in 5-HT $1 \mathrm{~F}$ but no change in $5-\mathrm{HT}_{1 \mathrm{D}}$ receptors in the hippocampus, Dean et al. did not find changes in the level of either receptor in the dorsolateral PFC. In the same study, however, Dean et al. (2006) found decreased $5-\mathrm{HT}_{7}$ receptor levels in the dorsolateral $\mathrm{PFC}$ of schizophrenia patients, using $\left[{ }^{3} \mathrm{H}\right] \mathrm{SB}-$ 269970 as the radiolabel, . By contrast, haloperidol treatment reportedly increased the number of 5$\mathrm{HT}_{7}$ receptors in the cortex of rats (Dean et al., 2006). The authors therefore concluded that 5- $\mathrm{HT}_{7}$ receptors are possibly involved in the pathological processes of schizophrenia and that appropriate 5$\mathrm{HT}_{7}$ receptor levels may be critical for normal cortical development. These recent findings on alterations of $\mathrm{HT}_{1 \mathrm{~F}}$ and $5-\mathrm{HT}_{7}$ receptors in schizophrenia need confirmation by additional postmortem studies and - more importantly - by PET studies.

\section{Serotonin transporter (SERT)}

Serotonin transporters (SERT) are located presynaptically on serotonergic axon terminals and are thought to serve as an index of serotonergic innervation (Abi-Dargham \& Krystal, 2000). Two early postmortem studies using $\left[{ }^{3} \mathrm{H}\right]$ cyanoimipramine and $\left[{ }^{3} \mathrm{H}\right]$ paroxetine showed that the density of SERT is decreased in the frontal cortex (Joyce et al., 1993; Laruelle et al., 1993a). In the study of Joyce et al., SERT levels were also decreased in the anterior and posterior cingulate cortices and increased in the striatum. Conversely, later studies of schizophrenia patients, performed with radiolabeled serotonin reuptake inhibitors (SRIs) such as $\left[{ }^{3} \mathrm{H}\right]$ paroxetine, $\left[{ }^{3} \mathrm{H}\right]$ citalopram and $\left[{ }^{125} \mathrm{I}\right] \mathrm{RTI}-55$, did not find any alterations of SERT density in multiple brain regions, including PFC and cingulate cortex (Dean et al., 1995; Dean et al., 1999b; Gurevich \& Joyce, 1997; Naylor et al., 1996). In fact, three of the studies did not detect any change in the density of SERT but did find a decrease in the affinity of $\left[{ }^{3} \mathrm{H}\right]$ paroxetine for SERT in the hippocampus (although the affinity of $\left[{ }^{3} \mathrm{H}\right]$ paroxetine for SERT in the frontal cortex was unaltered) (1996; Dean et al., 1995; Naylor et al., 1996). Gurevich and Joyce (Gurevich \& Joyce, 1997) concluded that the initial positive findings were probably confounded by the fact that the samples included a large number of schizophrenia patients who had committed suicide. The same may be true for the finding that SRIs have reduced affinity for SERT in the hippocampus, because Dean et al. (1996) have shown that this effect is more pronounced in schizophrenia patients who committed suicide.

Examining the expression of SERT mRNA, Hernandez and Sokolov (1997) found a four-fold increase in the level of SERT mRNA in the dorsolateral PFC and a two-fold decrease in the temporolateral cortex of schizophrenics. However, since these changes were strongly correlated with previous antipsychotic drug treatment, they cannot be attributed to the illness process.

A SPECT study using $\left[{ }^{123}\right.$ I]RTI-55 could not detect any differences in SERT concentration in midbrain areas of schizophrenia patients (Laruelle et al., 2000). However, $\left[{ }^{123} \mathrm{I}\right] \mathrm{RTI}-55$ is not specific 
for SERT but also labels the dopamine transporter (DAT) (Neumeyer et al., 1991). In addition, $\left[{ }^{123}\right.$ I]RTI-55 does not permit measurement of SERT availability in regions other than the midbrain (Laruelle et al., 1993b). Recently, Frankle et al. (2005) also failed to detect any differences in SERT binding between schizophrenia patients and controls when the more specific radiotracer $\left[{ }^{11} \mathrm{C}\right] \mathrm{DASB}$ was used. However, $\left[{ }^{11} \mathrm{C}\right] \mathrm{DASB}$ does not have a good signal-to-noise ratio when used in regions with low SERT density, such as the neocortex (Frankle et al., 2005), complicating detection of group differences. Two studies performed by Kim and colleagues $(2017 ; 2015)$ investigated SERT densities in schizophrenia patients using $\left[{ }^{11} \mathrm{C}\right] \mathrm{DASB}$, but only one of the studies found evidence of reduced SERT occupancy in the bilateral anterior hippocampus. Thus, taking all of these discrepant findings into account, SERT is unlikely to play an important role in the pathophysiology of schizophrenia.

\section{Genetic association studies regarding schizophrenia and serotonin}

During the period when psychiatric genetics was in its infancy, a large number of single association studies found significant associations between schizophrenia and common polymorphisms in serotonin receptor and transporter genes (for review see Baou et al., 2016). Meta-analyses of the SzGene online database across all available single genetic association studies for schizophrenia (Allen et al., 2008; www.schizophreniaforum.org) initially also confirmed that two serotonin-related single nucleotide polymorphisms (SNPs) were placed among the top 20 of the significant SNPs with a minor allele frequency of more than 10\% (status February 2012 published in Leach et al., 2013). The 5-HT $2 \mathrm{~A} A-$ 1438G polymorphism (rs6311) ranked seventh (odds ratio $(\mathrm{OR})=1.21$ ) and the tryptophan hydroxylase 1 (TPH1) A218C polymorphism (rs1800532) ranked fourteenth (OR = 1.17). However, the largest genome wide association study (GWAS) conducted to date, with 36,989 schizophrenia patients and 113,075 controls, did not list any serotonin pathway-related SNP among the top 108 significant variants (Ripke, 2014). Another recent schizophrenia GWAS, which included 11,260 cases and 24,542 controls and used genomic fine-mapping with brain expression and chromosome conformation data, identified six independent candidate causal gene sets associated with schizophrenia, including genes relating to the 5- $\mathrm{HT}_{2 \mathrm{C}}$ receptor (Pardiñas et al., 2018). Although the 5$\mathrm{HT}_{2 \mathrm{C}}$ receptor has not been a major focus of investigations regarding the pathophysiology of schizophrenia, preclinical animal models have suggested that the potent $5-\mathrm{HT}_{2 \mathrm{C}}$ receptor agonist vabicaserin may have efficacy in the treatment of the disease (Liu et al., 2014). Vabicaserin does not target dopamine receptors and shows high in vitro selectivity for $5-\mathrm{HT}_{2 \mathrm{C}}$ vs. $5-\mathrm{HT}_{2 \mathrm{~A}}$ and $5-\mathrm{HT}_{2 \mathrm{~B}}$ receptors (Dunlop et al., 2011). The first published study on the efficacy, safety and tolerability of vabicaserin in adults with acute schizophrenia showed some promising therapeutic effects, specifically on positive symptoms (Shen et al., 2014), but did not meet the primary efficacy endpoints, causing Pfizer to terminate further clinical development of the drug (Palacios et al., 2017). 
In two studies, it was shown that sensorimotor gating deficits in schizophrenia patients - which are viewed as an endophenotype of schizophrenia (Gottesman \& Gould, 2003) - are modulated by the strongly-linked 5- $\mathrm{HT}_{2 \mathrm{~A}} \mathrm{~A}-1438 \mathrm{G}$ and $\mathrm{T} 102 \mathrm{C}$ (rs6313) receptor SNPs (Quednow et al., 2008b). Although this gene effect on sensorimotor gating was replicated in a subsequent small study conducted in 94 normal subjects (Quednow et al., 2009), a recent meta-analysis including 44 schizophrenia risk SNPs and four data sets for the 5- $\mathrm{HT}_{2 \mathrm{~A}}$ receptor SNP rs6313 only showed a statistical trend for an association between this polymorphism and gating measures (Quednow et al., 2018).

In addition to focusing on schizophrenia, pharmacogenetic studies of serotonin system mutations have also examined drug response, as well as the risk for developing side-effects such as tardive dyskinesia and weight gain (for a comprehensive reviews see Arranz \& de Leon, 2007; Baou et al., 2016). However, findings with respect to potential links between tardive dyskinesia and 5-HT receptor polymorphisms remain controversial (Chang \& Fung, 2014), whereas antipsychotic-induced weight gain seems to be robustly associated with several $5-\mathrm{HT}_{2 \mathrm{C}}$ receptor variants based on a recent metaanalysis (Zhang et al., 2016). Given the strength of the reported associations, this discovery could potentially have a useful clinical application as a predictor of drug-induced weight gain (Arranz \& de Leon, 2007; Zhang et al., 2016). Another meta-analysis recently indicated that the treatment response to clozapine is significantly associated with the rs6313 and rs6314 variants 5- $\mathrm{HT}_{2 \mathrm{~A}}$ receptor gene and the rs1062613 polymorphisms within 5- $\mathrm{HT}_{3 \mathrm{~A}}$ receptor gene, reflecting an inheritable serotonergic modulation of the clinical response to clozapine (Gressier et al., 2016).

\section{Serotonergic mechanisms of atypical antipsychotics}

\section{5-HT $T_{2 A}$ receptor antagonism}

For many years, one of the most important arguments for the involvement of the serotonin system in the etiology of schizophrenia was the serotonergic action of most of the so-called atypical antipsychotics. Due to the clinical experience with first-generation antipsychotics, neuropharmacologists initially believed that extrapyramidal side effects (EPS) were an essential component of antipsychotic action. The antiquated term "neuroleptic" (Greek: "seize the nerve") specifically refers to this association (Lidow, 2000). The reason for the positive correlation between antipsychotic efficacy and EPS is that the therapeutic potency of the first-generation neuroleptics is proportional to their ability to block striatal $\mathrm{D}_{2}$ receptors, which is also the cause of EPS (Seeman et al., 1976). As a consequence, $D_{2}$ receptor blockade was proposed to be the principal mechanism of action of the neuroleptics discovered up to that point (Creese et al., 1976), including the phenothiazines chlorpromazine, perphenazine, fluphenazine, and thioridazine, the thioxanthenes thiothixene and flupentixol, and the butyrophenone haloperidol (which is still the most widely used neuroleptic drug). However, the dibenzodiazepine clozapine broke those rules, because its therapeutic effectiveness was not paired with notable EPS. Therefore, clozapine was described as an 'atypical' 
antipsychotic ${ }^{2}$. Unfortunately, the requirements for atypicality are not well defined. The narrowest definition is that atypical drugs have a lower incidence of EPS than typical drugs. However, in the last two decades several other prerequisites have been proposed: (1) atypical drugs have a lower capacity to elevate prolactin levels compared to typical antipsychotics; (2) atypical drugs ameliorate the negative and cognitive symptoms of schizophrenia to a greater extent than typical drugs; (3) atypical drugs have higher in vivo selectivity for corticolimbic $\mathrm{D}_{2}$ receptors compared to striatal $\mathrm{D}_{2}$ receptors; (4) atypical drugs have a serotonergic component to their action; (5) atypical drugs have higher affinity for 5- $\mathrm{HT}_{2 \mathrm{~A}}$ receptors than for $\mathrm{D}_{2}$ receptors; and (5) atypical drugs have a complex, multireceptor binding profile (Blin, 1999; Lidow, 2000; Meltzer, 1991, 1999; Seeman, 2002). It becomes clear that, in the end, all these definitions are derived from the multiple mechanisms of action of clozapine (see above), and thus only clozapine itself matches all of the criteria, reducing the concept of atypicality to an absurdity.

Although clozapine is still the gold-standard for antipsychotic efficacy, it has a not so rare (0.5-2\%) and potentially life-threatening side effect: agranulocytosis (Buchanan, 1995). Therefore, scientists aimed to develop novel antipsychotics having the antipsychotic potency but not the dangerous sideeffects of clozapine. Given that the superior efficacy of clozapine has been attributed to its high selectivity for 5- $\mathrm{HT}_{2 \mathrm{~A}}$ relative to $\mathrm{D}_{2}$ receptors (Meltzer, 1991; Meltzer et al., 1989), development of "balanced" 5- $\mathrm{HT}_{2 \mathrm{~A}} / \mathrm{D}_{2}$ antagonists as potential antipsychotics was initiated in the late 1980s (AbiDargham \& Krystal, 2000). This approach led to the discovery of novel antipsychotic drugs such as risperidone, olanzapine, quetiapine, ziprasidone, and sertindole. All these compounds have higher affinity for the $5-\mathrm{HT}_{2 \mathrm{~A}}$ receptor than for the $\mathrm{D}_{2}$ receptor, although none of them have as high a $\mathrm{D}_{2} / 5$ $\mathrm{HT}_{2 \mathrm{~A}}$ binding ratio as clozapine (only the dibenzoxazepine amoxapine has a higher ratio than clozapine) (Seeman, 2002). As a consequence, Meltzer (1999) proposed that atypical antipsychotics with a high $\mathrm{D}_{2} / 5-\mathrm{HT}_{2 \mathrm{~A}}$ binding ratio are more effective against negative symptoms, show a stronger improvement of cognitive functions, and cause less EPS than typical antipsychotics. Several clinical trials have shown that atypical antipsychotics with strong 5- $\mathrm{HT}_{2 \mathrm{~A}}$ antagonism - first and foremost clozapine - improve negative symptoms more efficaciously than typical compounds (e.g., Kane et al., 1988; Marder \& Meibach, 1994; Moller et al., 1995; Tollefson \& Sanger, 1997). However, metaanalyses revealed that atypical antipsychotics have rather moderate advantages in the treatment of negative symptoms (Carman et al., 1995; 2009; Leucht et al., 1999). Some scientists argued that these beneficial effects are only related to the improvement of secondary negative symptoms, which are correlated with the improvement of positive symptoms, depressive symptoms, EPS, or environmental deprivation, but that primary negative symptoms (also known as the 'deficit syndrome') are unaffected by atypicals (Buchanan et al., 1998; Carpenter et al., 1995; Lidow, 2000). Moreover, the view that 5$\mathrm{HT}_{2 \mathrm{~A}}$ receptor blockade is probably not required to improve negative symptoms is supported by a

\footnotetext{
${ }^{2}$ Second- or new-generation antipsychotics, multireceptor antipsychotics, or modern antipsychotics are often used (but not necessarily better) synonyms for atypical antipsychotics. Typical antipsychotics are also termed as classical or first-generation antipsychotics or neuroleptics, respectively.
} 
large meta-analyses showing that amisulpride - an atypical antipsychotic that acts as a selective $\mathrm{D}_{2} / \mathrm{D}_{3}$ and 5- $\mathrm{HT}_{7}$ receptor antagonist (Abbas et al., 2009) - has comparable efficacy to clozapine with regard to negative symptoms (2009; Leucht et al., 2002).

Cognitive dysfunction is a core symptom of schizophrenia, and improvement of cognitive function is highly relevant to functional outcomes such as social and occupational functioning (Green, 1996; Liddle, 2000). Many studies have shown that, when compared to haloperidol, the atypicals clozapine, risperidone, and olanzapine differently improved functioning in several cognitive domains, including semantic memory, verbal learning and memory, sustained attention, and working memory (Bilder et al., 2002; Kern et al., 1999; Meltzer \& McGurk, 1999; Purdon et al., 2000). However, most of these clinical trials did not use a control group or did not measure the control groups repeatedly. Meanwhile, recent data suggest that the measured cognitive improvements are only in the range of the expected test-retest enhancement (Goldberg et al., 2007; Quednow and Wagner, unpublished data). Additionally, in the large $(\mathrm{N}=817)$ CATIE (Clinical Antipsychotic Trials of Intervention Effectiveness) schizophrenia trial funded by the National Institute of Mental Health (NIMH), several atypical drugs only had small effects of on neurocognitive composite scores after 2, 6, and 18 months of continued treatment (Keefe et al., 2007). After 2 months, treatment with the atypicals ziprasidone $(\mathrm{z}=0.12)$, olanzapine $(\mathrm{z}=0.13)$, quetiapine $(\mathrm{z}=0.18)$, risperidone $(\mathrm{z}=0.26)$, as well as the typical antipsychotic perphenazine $(\mathrm{z}=0.25)$, produced only small but significant neurocognitive improvements, with no significant differences between treatment groups ( $\mathrm{z}$ is the least-squares mean improvement in the neurocognitive composite score). In contrast, after 18 months of treatment, neurocognitive enhancement was significantly greater in the perphenazine group than in the olanzapine and risperidone groups, despite the fact that perphenazine blocks $D_{2}$ receptors more strongly than it blocks $5-\mathrm{HT}_{2 \mathrm{~A}}$ receptors. This finding is in line with our previous data that treatment with the selective $D_{2} / D_{3}$ blocker amisulpride resulted in greater improvement in all cognitive domains (attention, executive function, working memory, and declarative memory) in schizophrenia patients compared to olanzapine, which is a clozapine-like atypical drug (Wagner et al., 2005). These data strongly call the following two hypotheses into question: (1) that atypical antipsychotics improve cognitive deficits beyond simple test-retest effects, and (2) that $5-\mathrm{HT}_{2 \mathrm{~A}}$ receptor blockade is necessary for the cognition-enhancing effects of atypical substances.

A recent meta-analysis showed that clozapine is still the antipsychotic drug with the lowest risk to produce EPS (measured by the use of antiparkinsonian medication), followed by sertindole and olanzapine (Leucht et al., 2009). Several suggestions have been made to explain the low incidence of EPS with clozapine treatment. The anticholinergic properties, the lack of an effect on acetylcholine release in the striatum, $\mathrm{D}_{1}$ and $\mathrm{D}_{4}$ receptor blockade, $\alpha_{1}$ - or $\alpha_{2}$-adrenoreceptor antagonism, and 5- $\mathrm{HT}_{2 \mathrm{~A}}$ receptor antagonism are all aspects of the action of clozapine that have been proposed to reduce the risk of EPS. Data from animal models of schizophrenia, as well as clinical data, suggest that a high level of 5- $\mathrm{HT}_{2 \mathrm{~A}}$ receptor blockade in combination with a low level of $\mathrm{D}_{2}$ receptor blockade may help 
to avoid EPS, whereas the $D_{1}$ receptor does not play a meaningful role (Meltzer, 1999; Roth \& Meltzer, 2000). Given that many atypical compounds can still induce EPS if higher doses are administered, 5- $\mathrm{HT}_{2 \mathrm{~A}}$ blockade may not be sufficient to reduce the incidence of EPS in the presence of very high levels of $\mathrm{D}_{2}$ occupation. However, 5- $\mathrm{HT}_{2 \mathrm{~A}}$ antagonism may reduce the risk for EPS when $\mathrm{D}_{2}$ receptors are not completely saturated (Abi-Dargham \& Krystal, 2000).

Animal studies first indicated that selective $5-\mathrm{HT}_{2 \mathrm{~A}}$ receptor antagonists lacking appreciable affinity for dopamine receptors may have antipsychotic properties (Geyer et al., 2001). The selective 5-HT $2 \mathrm{~A}$ receptor blocker MDL 100,907 was the first compound whose antipsychotic activity was exclusively predicted by preclinical animal models (Varty et al., 1999). In a subsequent clinical trial, MDL 100,907 was not significantly more effective than haloperidol in the treatment of schizophrenia, although it was more effective than placebo for reducing psychotic symptoms (de Paulis, 2001). Nevertheless, so far, there is no efficacious and approved antipsychotic medication without a dopaminergic mechanism-of-action. Moreover, the mechanism underlying the therapeutic superiority of clozapine is still unclear. While many hypotheses for atypicality have focused on the involvement of 5- $\mathrm{HT}_{2 \mathrm{~A}}$ receptors, an alternative hypothesis was proposed based on the unique $\mathrm{D}_{2}$ receptor binding kinetics exhibited by atypical drugs (Kapur \& Seeman, 2001). Data reported by Seeman (2002) indicate that most atypical drugs dissociate from the $\mathrm{D}_{2}$ receptor at a much faster rate than typical compounds. The dibenzapines clozapine and quetiapine and the benzamides amisulpride and remoxipride show the fastest dissociation from the $\mathrm{D}_{2}$ receptor. Seeman (2002) concluded that transient occupation of $\mathrm{D}_{2}$ allows relatively normal dopamine neurotransmission, which is likely to be a prerequisite for normal prolactin levels, intact cognition, and avoidance of EPS. This "fast-off- $\mathrm{D}_{2}$ " theory was strongly criticized because it applies only to clozapine and quetiapine and is inconsistent with the relatively slow dissociation of several atypical drugs, including olanzapine, risperidone, ziprasidone, and sertindole (Meltzer et al., 2003). However, so far there is no other theory that can explain the high antipsychotic efficacy of both clozapine and amisulpride.

Most likely, schizophrenia is not a homogeneous illness entity, but rather a cluster of diverse schizophreniform diseases with different pathogeneses. Thus, certain patients may show more benefit from a serotonergic compound. However, to date there are no criteria to safely predict the response to treatment with either antipsychotic.

\section{Role of other 5-HT receptors}

Most of the atypical antipsychotics bind to multiple 5-HT receptors (see Table 3). We briefly discuss the interaction of antipsychotics with $5-\mathrm{HT}_{1 \mathrm{~A}}, 5-\mathrm{HT}_{2 \mathrm{C}}, 5-\mathrm{HT}_{3}, 5-\mathrm{HT}_{4}, 5-\mathrm{HT}_{6}$, and $5-\mathrm{HT}_{7}$ receptors.

Numerous antipsychotics display activity at human $5-\mathrm{HT}_{1 \mathrm{~A}}$ receptors: aripiprazole, asenapine, clozapine, lurasidone, quetiapine, and ziprasidone display marked affinity for this site and act as agonists or partial agonists, whereas iloperidone, risperidone and sertindole display low affinity and act as antagonists. Moreover, several of the typical compounds, including haloperidol and 
chlorpromazine, also exhibit relatively low affinity and antagonist activity at 5- $\mathrm{HT}_{1 \mathrm{~A}}$ receptors (Newman-Tancredi et al., 1998; Shapiro et al., 2003). Thus, a specific 5- $\mathrm{HT}_{1 \mathrm{~A}}$ action does not appear to be necessary for antipsychotic activity. However, 5- $\mathrm{HT}_{1 \mathrm{~A}}$ agonist activity was proposed to enhance memory and cognition in schizophrenia because it was shown that: (1) $5-\mathrm{HT}_{1 \mathrm{~A}}$ receptors are concentrated in brain regions thought to mediate several cognitive functions (e.g., hippocampus, thalamus, cingulate cortex and PFC) (Roth et al., 2004); and (2) clozapine increases dopamine release in the PFC via 5-HT $1 \mathrm{~A}$ agonist effects (Rollema et al., 1997). In support of this hypothesis, Sumiyoshi et al. (Sumiyoshi et al., 2001a; 2001b) reported that chronic administration of the selective 5-HT $1 \mathrm{~A}$ receptor agonist tandospirone as a co-therapy with typical antipsychotics enhances verbal memory and executive function in schizophrenia patients. In contrast, chronic co-administration of the $5-\mathrm{HT}_{1 \mathrm{~A}}$ receptor partial agonist buspirone with atypical antipsychotics improved psychomotor speed but not memory or executive function in schizophrenia patients (Sumiyoshi et al., 2007). On the other hand, tandospirone had negative effects on memory function in demented patients (Yasuno et al., 2003), and the potent $5-\mathrm{HT}_{1 \mathrm{~A}}$ agonist NAE-086 induced hallucinations and nightmares in healthy volunteers after repeated administration (Renyi et al., 2001). Thus, use of a 5- $\mathrm{HT}_{1 \mathrm{~A}}$ partial agonist to augment cognitive enhancement in schizophrenia is only effective in combination with antipsychotics that lack 5- $\mathrm{HT}_{1 \mathrm{~A}}$ activity. Conversely, atypical antipsychotics with a 5-HT $\mathrm{HA}_{1 \mathrm{~A}}$ agonistic action should not be combined with $5-\mathrm{HT}_{1 \mathrm{~A}}$ receptor agonists or partial agonists because this may worsen psychotic symptoms and has no additional effect on cognition (Roth et al., 2004).

Clozapine has higher affinity for the 5- $\mathrm{HT}_{2 \mathrm{C}}$ receptor than for the 5- $\mathrm{HT}_{2 \mathrm{~A}}$ receptor. Animal studies first suggested that $5-\mathrm{HT}_{2 \mathrm{C}}$ receptor activation is inhibitory and $5-\mathrm{HT}_{2 \mathrm{~A}}$ receptor activation is stimulatory (Martin et al., 1997; 1998). This led to the conclusion that $5-\mathrm{HT}_{2 \mathrm{C}}$ receptor agonists may have antipsychotic effects (Abi-Dargham \& Krystal, 2000). Newer data have shown that 5- $\mathrm{HT}_{2 \mathrm{C}}$ receptor antagonists can directly increase dopamine release in the nucleus accumbens (NAC) and PFC (Di Matteo et al., 1998), while 5- $\mathrm{HT}_{2 \mathrm{C}}$ receptor agonists decrease dopamine and noradrenalin levels in the frontal cortex of rats (Millan et al., 1998). Administration of the 5- $\mathrm{HT}_{2 \mathrm{C} / 2 \mathrm{~A}}$ agonist m-CPP exacerbated the positive psychotic symptoms of schizophrenia, an effect that could be prevented by the $5-\mathrm{HT}_{2 \mathrm{C} / 2 \mathrm{~A}}$ antagonist ritanserin (Abi-Saab et al., 2002). Moreover, administration of ritanserin in combination with risperidone showed superior therapeutic efficacy compared to risperidone alone for negative symptoms in schizophrenia patients (Akhondzadeh et al., 2008). These results suggest that $5-\mathrm{HT}_{2 \mathrm{C}}$ blockade may actually have beneficial effects on positive, negative, and cognitive symptoms in schizophrenia (Meltzer et al., 2003). In contrast, earlier work demonstrated that 5- $\mathrm{HT}_{2 \mathrm{C}}$ receptor affinity did not distinguish typical from atypical antipsychotics (Roth et al., 1992). Furthermore, Meltzer et al. (2003) concluded that the high 5- $\mathrm{HT}_{2 \mathrm{C}}$ receptor affinity of certain atypical substances (e.g., clozapine, olanzapine, sertindole) roughly corresponds with their potential to produce weight gain rather than with their antipsychotic activity. 
Table 3: Affinities of selected antipsychotic drugs for 5-HT receptors, expressed as $p K_{i}$ (the - $\log _{10}$ of the binding affinity, $K_{i}$, in moles/L). Higher values indicate higher affinity. No value is shown if data were not available or if the $p K_{i}$ was below 3. All of the data are taken from the IUPHAR database (Harmar et al., 2009; http://www.guidetopharmacology.org).

\begin{tabular}{|c|c|c|c|c|c|c|c|c|c|c|c|}
\hline Drug & 5-HT1A & 5-HT1B & 5-HT1D & 5-HT1E & 5-HT1F & 5-HT2A & 5-HT2B & 5-HT2C & 5-HT5A & 5-HT6 & 5-HT7 \\
\hline Aripiprazol & $8.2^{\mathrm{ag}}$ & $6.1^{\mathrm{ag}}$ & $7.2^{\mathrm{ag}}$ & & & $7.5-8.1^{\mathrm{ag}}$ & & $7.6^{\mathrm{ag}}$ & & & \\
\hline Asenapine & $8.0-8.3^{\mathrm{ag}}$ & $8.1^{\mathrm{ag}}$ & $8.4^{\mathrm{ag}}$ & $8.0^{\mathrm{ag}}$ & & $10.2^{\text {ant }}$ & & & & & \\
\hline Chlorpromazine & $6.2^{\text {ant }}$ & & & & & $8.1^{\text {iag }}$ & & $7.6-8.2^{\mathrm{ant}}$ & & $7.7-7.8^{\mathrm{iag}}$ & $7.6^{\text {iag }}$ \\
\hline Clozapine & $6.8-6.9^{\mathrm{ag}}$ & $6.2^{\mathrm{ag}}$ & $6.4^{\mathrm{ag}}$ & $6.4^{\mathrm{ag}}$ & $6.9^{\mathrm{ag}}$ & $7.6-9.0^{\mathrm{iag}}$ & $8.0-8.8^{\text {ant }}$ & $7.4-8.7^{\text {iag }}$ & $6.0-6.5^{\mathrm{ant}}$ & $7.8-8.1^{\mathrm{iag}}$ & $7.2-7.8^{\mathrm{iag}}$ \\
\hline Haloperidol & $5.7-5.8^{\mathrm{ant}}$ & & $6.6^{\text {ant }}$ & & & $6.7-7.3^{\mathrm{ant}}$ & $5.8-6.4^{\text {ant }}$ & & & & $6.3-6.6^{\mathrm{ant}}$ \\
\hline Iloperidone & $7.0^{\text {ant }}$ & & & & & & & & & $7.2^{\text {ant }}$ & $7.0^{\text {ant }}$ \\
\hline Lurasidone & $8.2^{\mathrm{ag}}$ & & & & & $8.7^{\text {ant }}$ & & & & & $9.3^{\mathrm{ant}}$ \\
\hline Olanzapine & $5.6-5.8^{\mathrm{ag}}$ & $6.3^{\mathrm{ag}}$ & $6.2^{\mathrm{ag}}$ & $5.7^{\mathrm{ag}}$ & $6.5^{\mathrm{ag}}$ & $8.6-8.7^{\mathrm{ant}}$ & & $8.1-8.2^{\text {iag }}$ & & $8^{\text {iag }}$ & $6.5^{\text {ant }}$ \\
\hline Perphenazine & & & & & & $8.2^{\mathrm{ant}}$ & & $6.9^{\text {ant }}$ & & $7.1^{\text {iag }}$ & $7.2^{\mathrm{iag}}$ \\
\hline Quetiapine & $6.5-6.6^{\mathrm{ag}}$ & & $5.7^{\mathrm{ag}}$ & $5.9^{\mathrm{ag}}$ & $5.6^{\mathrm{ag}}$ & $6.4-7.0$ & & & & & \\
\hline Risperidone & $6.4-6.5^{\mathrm{ant}}$ & $6.6-7.0^{\mathrm{ant}}$ & $7.8-8.0^{\mathrm{ant}}$ & $5.9^{\text {ant }}$ & $5.9^{\text {ant }}$ & $9.3-10.0^{\mathrm{iag}}$ & & $7.5-7.6^{\mathrm{iag}}$ & & $5.6^{\mathrm{ant}}$ & $8.3-8.7^{\text {iag }}$ \\
\hline Sertindole & $6.4-6.6^{\mathrm{ant}}$ & $7^{\text {ant }}$ & $7.2^{\text {ant }}$ & $6.4^{\text {ant }}$ & $6.4^{\mathrm{ant}}$ & $9.2-9.4^{\mathrm{ant}}$ & & $9.0-9.2^{\text {iag }}$ & & & \\
\hline Ziprasidone & $7.9-8.9^{\text {pag }}$ & $8.3^{\mathrm{ag}}$ & $9^{\mathrm{ag}}$ & $6.4^{\mathrm{ag}}$ & & $8.8-9.5^{\text {ant }}$ & & $7.9-8.4^{\mathrm{iag}}$ & & & $8.4^{\text {iag }}$ \\
\hline
\end{tabular}

\section{ag = agonist}

ant $=$ antagonist

pag $=$ partial agonist

iag = inverse agonist 
However, some clinical data did suggest that augmentation with the 5- $\mathrm{HT}_{2 \mathrm{C} / 2 \mathrm{~A}}$ antagonists ritanserin and mianserin may have some beneficial effects in schizophrenia, especially on negative and cognitive symptoms (Akhondzadeh et al., 2008; Lieberman et al., 1998; Meltzer et al., 2003). As discussed above, the potent $5-\mathrm{HT}_{2 \mathrm{C}}$ receptor agonist vabicaserin showed some efficacy against positive symptoms in adults with acute schizophrenia (Shen et al., 2014), but its clinical development was terminated because the overall clinical endpoints were not reached (Palacios et al., 2017).

$5-\mathrm{HT}_{3}$ receptor antagonists have also been investigated as potential antipsychotics because clozapine has moderate affinity for this receptor and because preclinical animal studies linked the site to possible antipsychotic efficacy (Lieberman et al., 1998). Although the selective 5-HT 3 receptor antagonist ondansetron had moderate antipsychotic activity in an open-label and uncontrolled clinical trial (DeVeaugh-Geiss et al., 1992), these results were not replicated in a double-blind study (Gaster \& King, 1997). In addition, the 5- $\mathrm{HT}_{3}$ antagonist zacopride is not effective in the treatment of schizophrenia (Newcomer et al., 1992), suggesting that the 5- $\mathrm{HT}_{3}$ receptor is not a promising drug target for the disorder.

Given that $5-\mathrm{HT}_{4}$ receptors modulate acetylcholine and $\mathrm{GABA}$ release and that $5-\mathrm{HT}_{4}$ receptors are found in high densities in the frontal cortex and the hippocampus, it was suggested that modification of $5-\mathrm{HT}_{4}$ receptor activity may be helpful for improving cognition in schizophrenia. Several animal studies support this proposal, but studies in healthy human volunteers and schizophrenia patients are lacking (Gray \& Roth, 2007; Roth et al., 2004). Since atypical antipsychotic drugs are devoid of major $5-\mathrm{HT}_{4}$ receptor actions, Roth et al. (2004) proposed that a 5- $\mathrm{HT}_{4}$ partial agonist would be beneficial as an add-on therapy for improving cognition in schizophrenia.

On the basis of animal studies, the 5- $\mathrm{HT}_{6}$ receptor was also suggested to be a promising drug target for cognition in schizophrenia (Gray \& Roth, 2007; Meltzer et al., 2003; Roth et al., 2004). The 5-HT6selective antagonist SB-271046 showed pro-cognitive effects in preclinical tests (Da Silva Costa et al., 2009; Hatcher et al., 2005; Marcos et al., 2008; Quiedeville et al., 2015; Woods et al., 2012). However, several typical (e.g., chlorpromazine, fluphenazine) and atypical (e.g., clozapine, iloperidone, olanzapine, ziprasidone and quetiapine) antipsychotics have high affinity for the 5- $\mathrm{HT}_{6}$ receptor, making it unlikely that addition of a 5- $\mathrm{HT}_{6}$ antagonistic drug would further improve cognition in schizophrenia patients treated with these antipsychotics (Roth et al., 1994; Roth et al., 2004). Moreover, both $5-\mathrm{HT}_{6}$ agonists and antagonists show pro-cognitive effects in preclinical studies, but an explanation for these paradoxical effects is currently missing (Fone, 2008). Thus, further studies are needed to understand the role of the $5-\mathrm{HT}_{6}$ receptor in the modulation of cognition and to develop 5- $\mathrm{HT}_{6}$ antagonist compounds as treatments for the cognitive deficits in schizophrenia. Amisulpride, clozapine, iloperidone, lurasidone, and risperidone, as well as the typical drugs chlorpromazine, fluphenazine, and pimozide, all have high affinity for the 5- $\mathrm{HT}_{7}$ receptor (Abbas et al., 2009; Roth et al., 1994) (see also Table 3); this suggests that a $5-\mathrm{HT}_{7}$ action is not a specific feature of atypicality (Abi-Dargham \& Krystal, 2000). Evidence primarily drawn from studies in 
receptor knock-out mice indicate that the $5-\mathrm{HT}_{7}$ receptor plays an important role in hippocampusdependent functions, including learning and memory (Gray \& Roth, 2007). These data warrant further investigation of the potential use of $5-\mathrm{HT}_{7}$ receptor antagonists in the treatment of memory dysfunction in schizophrenia (Gray \& Roth, 2007).

\section{Antipsychotic drug action and serotonin receptor occupancy}

Traditionally, most of the molecular imaging studies investigating the role of receptor occupancy in antipsychotic activity by PET or SPECT have focused on the dopamine system. In these studies, it was consistently shown that typical antipsychotics usually produce higher striatal $\mathrm{D}_{2}$ receptor occupancy levels $(>70 \%)$ than atypical antipsychotics $(<70 \%)$ at mean therapeutic doses (Kasper et al., 1999; Lieberman et al., 1998; Weinberger \& Laruelle, 2002). Because the atypicals clozapine and quetiapine display the lowest rates of $\mathrm{D}_{2}$ occupancy (20-67\%) at clinically effective doses, and given that most of the studies could not demonstrate a linear correlation between striatal $\mathrm{D}_{2}$ binding and therapeutic efficacy, it appears that striatal $\mathrm{D}_{2}$ receptor occupancy rates are not sufficient to explain antipsychotic activity (Kasper et al., 1999; Weinberger \& Laruelle, 2002). On the contrary, several studies consistently found a clear correlation between EPS and striatal $\mathrm{D}_{2}$ receptor occupancy, indicating a high likelihood of EPS when $\mathrm{D}_{2}$ occupancy exceeds a threshold of $80 \%$ (Kasper et al., 1999; Weinberger \& Laruelle, 2002; Zipursky et al., 2007). Since at least $50-60 \% \mathrm{D}_{2}$ receptor occupancy is required to observe a rapid clinical response with typical antipsychotics such as haloperidol, an optimal antipsychotic dose range resulting in $70-80 \% \mathrm{D}_{2}$ occupancy was suggested (Kapur et al., 2000; Nordstrom et al., 1993; Nyberg et al., 1999). However, this rule does not apply to clozapine and quetiapine.

In line with the in vivo data (see above), when dual-tracer approaches are used, most of the atypical drugs display higher levels of occupancy at 5- $\mathrm{HT}_{2 \mathrm{~A}}$ than at $\mathrm{D}_{2}$ (Gefvert et al., 2001; Kapur et al., 1998; Mamo et al., 2004; Nyberg et al., 1999). Although it was suggested that the predominant 5-HT $2 \mathrm{~A}$ receptor antagonism produced by atypical drugs protects against EPS (Meltzer, 1999), even atypical substances such as olanzapine or risperidone can cause EPS when given in high doses that lead to > $80 \% \mathrm{D}_{2}$ receptor occupancy (Kapur et al., 1998; Nyberg et al., 1999). Thus, 5- $\mathrm{HT}_{2 \mathrm{~A}}$ receptor occupancy does not confer protection against EPS because the threshold of $\mathrm{D}_{2}$ receptor occupancy associated with EPS is not markedly reduced for atypical substances with a balanced $5-\mathrm{HT}_{2 \mathrm{~A}} / \mathrm{D}_{2}$ receptor profile (Weinberger \& Laruelle, 2002). Compared to the other atypicals, aripiprazole is an interesting exception with regard to its $\mathrm{D}_{2}, 5-\mathrm{HT}_{2 \mathrm{~A}}$, and $5-\mathrm{HT}_{1 \mathrm{~A}}$ receptor occupancy. A recent study found that aripiprazole, at doses between 10 to $30 \mathrm{mg}$ in schizophrenia patients, exhibits very high striatal $\mathrm{D}_{2}$ occupancy (81-94\%), lower occupancy at frontal and temporal 5- $\mathrm{HT}_{2 \mathrm{~A}}$ receptors $(31-84 \%)$, and even lower occupancy at frontal and temporal 5- $\mathrm{HT}_{1 \mathrm{~A}}$ receptors (-2-44\%). EPS was only observed in two of four subjects with $\mathrm{D}_{2}$ occupancies exceeding 90\% (Mamo et al., 2007). In accordance with the study of Bantick et al. (2004), who showed that clozapine did not occupy the 5- $\mathrm{HT}_{1 \mathrm{~A}}$ receptor at 
clinical doses, these data do not support an important role of the 5- $\mathrm{HT}_{1 \mathrm{~A}}$ receptor in antipsychotic activity. In sum, molecular imaging studies do not support the view that the $5-\mathrm{HT}_{2 \mathrm{~A}}$ or $5-\mathrm{HT}_{1 \mathrm{~A}}$ mechanism of several atypical drugs contributes significantly to their clinical superiority.

\section{Serotonergic challenge studies}

Given that the release of hormones such as cortisol, prolactin, and growth hormone (GH) is under monoaminergic control, the neuroendocrine challenge paradigm is suitable to investigate the functional state of central monoaminergic systems. In a hypersensitive system, stimulation of 5-HT receptors will induce an augmented hormonal release, whereas in a hypoactive system, increased release would not be expected. If 5-HT receptors are blocked, then the opposite results are anticipated (Murphy et al., 1986).

Early neuroendocrine challenge studies conducted in small samples of schizophrenia patients and employing the 5-HT precursors tryptophan and 5-hydroxytryptophan (5-HTP) reported inconsistent results. Two studies reported an increased prolactin response and a blunted GH release (Cowen et al., 1985; Kolakowska et al., 1987). One study found decreased prolactin responses and decreased GH responses in long-term haloperidol-treated patients, whereas short-term treatment did not cause patients to differ from controls on these measures (Hoshino et al., 1985). However, precursor effects are relatively muted because of their 'upstream' (and therefore secondary) actions on synaptic function making these studies difficult to interpret (Breier, 1995).

Challenge studies with the serotonin releasers fenfluramine and d-fenfluramine also provided conflicting results. An initial study reported a decreased prolactin release in chronic patients (Lerer et al., 1988), whereas two later studies found prolactin hyperresponsivity in drug-free patients (Abel et al., 1996; Monteleone et al., 1999). However, in the study of Monteleone et al. (1999), the elevated prolactin response was restricted to patients who were refractory to typical neuroleptics. In line with that finding, Mohr et al. (1998) reported that a poor treatment response to haloperidol in unmedicated first-episode patients was associated with a higher prolactin response to d-fenfluramine challenge (indicating a higher responsiveness of the 5-HT system). Additionally, Sharma et al. (1999) found that that a higher prolactin response to dl-fenfluramine was correlated with more negative symptoms. These studies also varied with regard to psychotic symptom provocation after fenfluramine: some reported no changes, while others reported exacerbation of positive symptoms.

The serotonin and noradrenaline reuptake inhibitor clomipramine, which also acts as a 5- $\mathrm{HT}_{2}$ receptor antagonist, provoked an increased prolactin response in drug-naïve schizophrenia patients, an effect that was positively correlated with the duration of illness and negatively correlated with treatment response (Angelopoulos et al., 2002). However, another study did not find changes in clomipramineinduced the prolactin release in patients treated with typical antipsychotics (Markianos et al., 2001).

The drug $m$-chlorophenylpiperazine (m-CPP) acts as a partial agonist at 5- $\mathrm{HT}_{2 \mathrm{C}}$ receptors and as an antagonist at 5- $\mathrm{HT}_{2 \mathrm{~A}}$ receptors, but also binds to several other 5-HT receptor subtypes (Kahn \& 
Wetzler, 1991). m-CPP increases anxiety, body temperature, and plasma levels of prolactin, cortisol, $\mathrm{GH}$, and $\mathrm{ACTH}$, but does not provoke psychotic symptoms in healthy human volunteers (Breier, 1995). Schizophrenia patients show either blunted (Iqbal et al., 1991; Maes \& Meltzer, 1996) or normal prolactin responses to m-CPP (Kahn et al., 1992; Krystal et al., 1993). Moreover, m-CPP has been reported to exacerbate (Abi-Saab et al., 2002; Iqbal et al., 1991; Krystal et al., 1993), reduce (Kahn et al., 1992), or have no effect on psychotic symptoms (Breier et al., 1993; Koreen et al., 1997; Owen et al., 1993). Clozapine has been reported to block the symptom-worsening and hormonereleasing effects of $\mathrm{m}-\mathrm{CPP}$, which was attributed to the $5-\mathrm{HT}_{2 \mathrm{C}}$ antagonistic effects of clozapine (Breier et al., 1993; Kahn et al., 1993b; Krystal et al., 1993; Owen et al., 1993). Similar effects were shown for olanzapine (Abi-Saab et al., 2002) and the 5-HT 2 antagonist ritanserin (Scheepers et al., 2001a).

In general, the contradictory results across the different serotonergic challenge studies point to heterogeneity in central serotonergic sensitivity within different subpopulations of schizophrenia patients. This assumption is also supported by the consistent observation that a hypersensitive 5-HT system is associated with poor treatment response to mostly typical antipsychotics. Serotonergic challenge studies may therefore be useful for tailoring individualized antipsychotic pharmacotherapy.

\section{Serotonin metabolites in cerebrospinal fluid}

Many studies have measured monoamine metabolite concentrations in the cerebrospinal fluid (CSF) of schizophrenia patients in order to investigate central 5-HT and dopamine turnover. Most of the early studies did not find changes in the CSF concentration of 5-HIAA, the major 5-HT metabolite, but some studies reported decreased 5-HIAA CSF levels in schizophrenia (for review and references see Bleich et al., 1991). A more recent meta-analysis, as well as a recent study with a large sample of schizophrenia patients, supported the view that mean 5-HIAA CSF concentrations are generally relatively unaltered in schizophrenia patients (Tuckwell \& Koziol, 1996; Wieselgren \& Lindstrom, 1998). In contrast, another meta-analysis indicated that CSF levels of homovanillic acid (HVA), the main metabolite of dopamine, are lowered in schizophrenia patients (Tuckwell \& Koziol, 1993); this finding was confirmed by a more recent study conducted with 90 schizophrenia patients and 47 healthy controls (Wieselgren \& Lindstrom, 1998). Studies linking specific characteristics of the illness with 5-HIAA CSF levels have shown that low 5-HIAA concentrations are associated with advanced brain atrophy (Jennings et al., 1985; Losonczy et al., 1986; Nyback et al., 1983; Potkin et al., 1983), more prominent negative symptoms (Csernansky et al., 1990; Pickar et al., 1986), and failure to activate the PFC during the Wisconsin Card Sorting Test (Weinberger et al., 1988). However, all of these measures have been found to be associated with decreased HVA CSF levels as well (Csernansky et al., 1990; Jennings et al., 1985; Losonczy et al., 1986; Nyback et al., 1983; Pickar et al., 1986; Potkin et al., 1983; Scheepers et al., 2001b). However, one of the best replicated findings in biological psychiatry is the strong intercorrelation of monoamine metabolites in the CSF, which possibly could 
be explained by similar transport mechanisms for all monoamines (Hsiao et al., 1993). This idea has led to the approach of calculating HVA/5-HIAA concentration ratios to investigate the relationship between serotonergic and dopaminergic activity in schizophrenia (Hsiao et al., 1993). Lewine et al. (1991) demonstrated for example that the HVA/5-HIAA ratio was a better predictor of the extent of brain atrophy than either HVA or 5-HIAA CSF levels alone (see also Nyback et al., 1983). Additionally, while 5-HIAA and HVA levels alone could not predict treatment outcome, a low HVA/5-HIAA CSF ratio was significantly associated with better response to clozapine and typical antipsychotics in several studies (Kahn et al., 1993a; Lieberman et al., 1994; Pickar et al., 1992; Risch, 1995; Risch \& Lewine, 1993; Szymanski et al., 1993). These results suggested that antipsychotic effects are associated with changes in dopamine function relative to 5-HT function, rather than changing dopamine or 5-HT function per se (Scheepers et al., 2001b). However, in at least two studies, HVA/5-HIAA CSF ratios lacked predictive value regarding the treatment response to olanzapine, clozapine, or haloperidol (Jacobsen et al., 1997; Scheepers et al., 2001b), while one study found a worse long-term outcome in patients with low HVA/5-HIAA CSF ratios (Wieselgren \& Lindstrom, 1998). These discrepancies may be explained by differences in patient populations, duration of treatment, method of analysis, or criteria for evaluating the therapeutic response.

Surprisingly, several investigations demonstrated that neither typical nor atypical antipsychotics changed 5-HIAA CSF levels during the course of treatment, although many of these substances strongly affect the 5-HT system (Jacobsen et al., 1997; Kahn et al., 1994; Scheepers et al., 2001b; van Kammen et al., 1986; Wieselgren \& Lindstrom, 1998). These results questioned the idea that 5-HIAA CSF concentrations are a valid marker of the central 5-HT turnover. Moreover, it was suggested that 5-HIAA concentrations may not mirror 5-HT metabolism in the whole brain, but rather reflect turnover in specific brain regions such as frontal cortex and striatum (Scheepers et al., 2001b). On the contrary, typical antipsychotics seem to consistently elevate HVA CSF levels and HVA/5-HIAA CSF ratios, while atypical substances did not (Hsiao et al., 1993; Kahn et al., 1993a; Scheepers et al., 2001b; Wieselgren \& Lindstrom, 1998).

In sum, investigations of 5-HT metabolite levels in the CSF in schizophrenia are difficult to interpret because the specific neuronal substrate of 5-HIAA CSF levels is not clear. However, there is some consistency in the data showing that at least a subpopulation of patients display changes in global 5HT and dopamine turnover, and these patients may respond differentially to antipsychotics compared to other subpopulations. 


\section{Platelet studies}

Human blood platelets have been proposed as a peripheral model of central 5-HT function because platelets are neuroectodermal derivatives that share several biochemical and morphological characteristics with 5-HT synapses (Bleich et al., 1991).

Most of the studies investigating platelet or whole blood 5-HT concentrations in schizophrenia patients found elevated values, although there are also some contradictory results (for review see Bleich et al., 1991; and Iqbal \& van Praag, 1995). The increase in peripheral 5-HT concentrations reported in the early studies was apparently not an artifact of medication, as no in vivo effect of antipsychotics on platelet 5-HT could be demonstrated (Bleich et al., 1991). On the contrary, accumulating evidence suggests that treatment with clozapine and other atypical and typical antipsychotics increases 5-HT plasma levels in schizophrenia patients (Ertugrul et al., 2007; Fleischhaker et al., 1998; Joseph et al., 1977; Schulz et al., 1997; van der Heijden et al., 2004). These findings suggest that antipsychotics still have an impact on peripheral 5-HT concentrations and indicate that medication may have indeed influenced previous results.

The findings on platelet 5-HT uptake are less consistent. The amount of studies reporting reduced or unchanged platelet 5-HT uptake is more or less equal (for review see Bleich et al., 1991; and Iqbal \& van Praag, 1995). However, Arora and Meltzer (1983) have convincingly demonstrated that a two week treatment with chlorpromazine significantly decreased platelet 5-HT uptake in schizophrenia patients and healthy controls. Thus, previous findings of reduced platelet 5-HT uptake in schizophrenia patients are likely explained by acute or residual antipsychotic treatment effects. Moreover, several studies investigating $\left[{ }^{3} \mathrm{H}\right]$ imipramine binding sites on platelets, which have been suggested as another measure of 5-HT uptake or transport, predominantly yielded no differences between normals and schizophrenia patients (for review see Bleich et al., 1991; and Iqbal \& van Praag, 1995).

Platelet 5- $\mathrm{HT}_{2 \mathrm{~A}}$ receptors are identical with brain 5- $\mathrm{HT}_{2 \mathrm{~A}}$ receptors in terms of their pharmacological properties (Ostrowitzki et al., 1993). Although Arora and Meltzer (1983) detected an increased density of 5- $\mathrm{HT}_{2 \mathrm{~A}}$ receptors on platelets from suicidal schizophrenia patients, a newer study reported increased platelet 5- $\mathrm{HT}_{2 \mathrm{~A}}$ receptor levels in chronic, medication-free schizophrenia patients (Arranz et al., 2003). Given that treatment with risperidone strongly increased platelet 5- $\mathrm{HT}_{2 \mathrm{~A}}$ receptor density, Arranz et al. (2003) concluded that the increased platelet $5-\mathrm{HT}_{2 \mathrm{~A}}$ receptor density in their drug-free sample was a residual drug effect caused by previous antipsychotic treatment. Additionally, these authors reported recently that low baseline platelet $5-\mathrm{HT}_{2 \mathrm{~A}}$ receptor levels may predict clinical response to olanzapine in a group of antipsychotic-naïve schizophrenia patients (Arranz et al., 2007).

The activity of platelet monoamine oxidase (MAO) activity has also been studied in schizophrenia, demonstrating results similar to platelet $5-\mathrm{HT}_{2 \mathrm{~A}}$ receptor density. Although there are some indications of decreased platelet MAO activity at least in some subgroups of schizophrenia patients (Zureick \& 
Meltzer, 1988), it could not be excluded that this effect is primarily caused by antipsychotic treatment (DeLisi et al., 1981; Ertugrul et al., 2007; Ohuoha et al., 1993).

It should be noted that the changes of serotonergic markers found in platelets are largely in the opposite direction than the alterations that were found in more centrally relevant 5-HT measures in schizophrenia patients (decreased 5-HT in CSF and brain tissue vs. increased 5-HT in blood and platelets; decreased 5-HT receptors in several brain regions vs. increased 5- $\mathrm{HT}_{2 \mathrm{~A}}$ receptor density in platelets, and so on). In addition, treatment with antipsychotics also had mostly opposite effects on platelet and brain 5-HT markers, respectively. These facts suggest that platelets are not an ideal model for brain 5-HT function (Roth \& Meltzer, 2000).

\section{Neurotrophic role of serotonin in the developmental disorder schizophrenia}

As reviewed by Whitaker-Azmitia in this volume, serotonin plays a major role at several stages of neuroplasticity. During embryogenesis the serotonin system is one of the first neurotransmitter systems that innervates brain structures and demonstrates functional activity. In this phase, serotonin acts as a growth factor that influences neuronal and glial morphology, and connectivity. Some of these effects are direct, whereas some others are mediated by the interaction with further chemical messengers (such as brain-derived neurotrophic factor [BDNF] or S100 $\beta$ ) and other neurotransmitter systems (such as dopamine, GABA, and glutamate). But postnatal serotonin also influences the formation and degradation of synapses and axon terminals, indicating that serotonin is important not only for neuronal development but also for the preservation and maintenance of normal function in the adult brain (see also Sodhi \& Sanders-Bush, 2004).

Accumulating evidence from several domains suggests that schizophrenia could be a neurodevelopmental disorder that is - at least in part - caused by aberrant early brain development: (1) Many schizophrenia patients exhibit delayed developmental milestones in childhood, including cognitive, motor, and behavioral abnormalities, which indicates abnormal brain function prior to diagnosis of schizophrenia, (2) Obstetric complications and prenatal infections increase the risk for schizophrenia, (3) Postmortem studies did not find indicators for neurodegenerative processes such as gliosis or loss of neurons in the brain of schizophrenia patients, and (4) several anatomical and functional disruptions are associated with exacerbation of schizophrenia in adulthood and these disruptions can be simulated in developmental animal models (Marenco \& Weinberger, 2000; Miyamoto et al., 2003). As suggested by Murray et al. (1992), aberrant developmental processes may play a major role, especially in the congenital subform of schizophrenia that shows a gradual increase in behavioral disturbances until the disorder is diagnosed in adolescence or early adulthood. Maynard and colleagues (2001) have proposed a two-hit hypothesis of schizophrenia. According to their suggestion a lesion occurring in early neurodevelopment (first hit), caused by a genetic load or adverse embryonic and perinatal events, in combination with a second hit, arising from hormonal events, excitotoxicity, psychosocial stress, or oxygen radical formation, may cause schizophrenia. 
Immunocytochemical and ultrastructural postmortem studies have demonstrated neurocellular alterations in schizophrenia, such as decreased neuronal size, increased cellular packing density, fewer dendritic spines and synapses, and distortions in neuronal orientation (for review see Arnold, 1999). The abnormalities in the cytoarchitecture, such as neuronal disarray, heterotopias, and malpositioning, indicate disruption of proliferation or migration at the gestational period (Miyamoto et al., 2003). In accordance, it was consistently shown that the expression of reelin, a glycoprotein that regulates neuronal migration, is strongly decreased in schizophrenia patients (Guidotti et al., 2000; Impagnatiello et al., 1998). Moreover, anatomical studies found enlargements of the lateral and third ventricles in conjunction with a decrease in cortical volume, especially within the hippocampal formation and the amygdala; additionally, subcortical structures appear to be reduced in size, including the thalamus and striatum (for review see Sodhi \& Sanders-Bush, 2004). It is unlikely that these macrostructural alterations are simply caused by neurodegenerative processes because some of these alterations have been shown also at a prodromal state of schizophrenia (Jessen et al., 2006; Morey et al., 2005; Wood et al., 2003), and postmortem studies did not find gliosis and neuronal cell loss. Thus, these anatomical and cytoarchitectual changes are likely to arise during brain maturation. Several lines of evidence suggest that abnormalities in brain development may contribute to the pathogenesis of schizophrenia in a subset of patients. Moreover, we know that serotonin plays an important role in neurogenesis and neuronal plasticity. However, future studies will have to determine whether genetic or early developmental insults could alter the serotonin system in a manner that leads to sustained neuronal changes during brain development, which consequently induces the symptoms of schizophrenia.

\section{Serotonin-glutamate interactions}

NMDA receptor antagonists such as phencyclidine (PCP) and ketamine produce effects in humans that mimic some of the symptoms of schizophrenia (Javitt \& Zukin, 1991; Krystal et al., 1994). Microdialysis studies have demonstrated that ketamine and PCP increase glutamate outflow in PFC (Adams \& Moghaddam, 1998; Moghaddam et al., 1997). Potentially related to this effect is evidence that increases in glutamatergic activity may contribute to the psychotomimetic and behavioral effects of these drugs. Indeed, diminution of PCP-induced glutamate release by activation of metabotropic glutamate $2 / 3\left(\mathrm{mGlu}_{2 / 3}\right)$ receptors attenuates the effects of PCP on locomotor activity and stereotypy (Moghaddam \& Adams, 1998). Other agents that decrease glutamate release also reduce the behavioral effects of PCP and ketamine (Anand et al., 2000; Idris et al., 2005). In each of these cases, the actions of the released glutamate would presumably be on non-NMDA glutamate receptors, either AMPA, kainate, or metabotropic, since PCP and ketamine block NMDA receptor functions. The involvement of glutamate release in the psychotomimetic effects of NMDA antagonists is consistent with the hypothesis that dysfunction of glutamatergic systems underlies the psychopathology of schizophrenia (Halberstadt, 1995; Javitt \& Zukin, 1991; Jentsch \& Roth, 1999). 
Electrophysiological evidence demonstrates that LSD and other serotonergic hallucinogens can modulate cellular responses to glutamate (Arvanov et al., 1999; Rahman \& Neuman, 1993). Recent studies indicate that hallucinogens increase the release of glutamate in neocortex (Muschamp et al., 2004; Scruggs et al., 2003). Activation of 5- $\mathrm{HT}_{2 \mathrm{~A}}$ receptors by 5-HT and the hallucinogen DOI produces an enhancement of the frequency and amplitude of spontaneous excitatory postsynaptic potentials/currents (EPSPs/EPSCs) in most layer V pyramidal cells of PFC (Aghajanian \& Marek, 1997; Benneyworth et al., 2007; Klodzinska et al., 2002; Lambe et al., 2000); this effect is mediated by increased glutamate efflux and subsequent activation of AMPA receptors (Zhang \& Marek, 2008). There is also evidence that 5-HT- and DOI-induced EPSCs are suppressed by activation of $\mathrm{mGlu}_{2 / 3}$ receptors, and are augmented by $\mathrm{mGlu}_{2 / 3}$ receptor blockade (Benneyworth et al., 2007; Klodzinska et al., 2002; Marek et al., 2000). Although it is generally accepted that 5- $\mathrm{HT}_{2 \mathrm{~A}}$ receptor activation increases the terminal release of glutamate in PFC, there has been some controversy regarding the source of these glutamatergic terminals. Based on evidence that lesions of the medial thalamus attenuate 5-HT-induced EPSCs, Marek and colleagues have argued that thalamocortical afferents are involved (Marek et al., 2001). However, Béique et al. (2007) recently identified a subpopulation of pyramidal cells in the deep layers of $\mathrm{PFC}$ that are excited by $5-\mathrm{HT}_{2 \mathrm{~A}}$ receptor activation, indicating that the spontaneous EPSCs evoked by 5-HT may be a product of PFC recurrent network activity.

As was found with PCP, the behavioral effects of serotonergic hallucinogens are attenuated by activation of $\mathrm{mGlu}_{2 / 3}$ receptors. The ability of DOI to induce the head twitch response in mice and rats is suppressed by the selective mGlu $_{2 / 3}$ agonists LY354740 and LY379268; conversely, the selective mGlu $_{2 / 3}$ antagonist LY341495 enhances the frequency of DOI-induced head twitch (Gewirtz \& Marek, 2000; Klodzinska et al., 2002). Likewise, the $\mathrm{mGlu}_{2}$ positive allosteric modulator biphenyl-indanone A inhibits the head twitch response induced by the hallucinogen (-)-2,5-dimethoxy-4bromoamphetamine (DOB) (Benneyworth et al., 2007). It has also been shown that the discriminative stimulus effects of LSD are potentiated by LY341495 and partially antagonized by LY379268 (Winter et al., 2004). The ability of $\mathrm{mGlu}_{2 / 3}$ receptor ligands to alter the behavioral response to DOI, DOB, and LSD indicates that the behavioral effects of hallucinogens are linked to their ability to increase glutamate release.

Taken together, the aforementioned findings demonstrate that NMDA receptor antagonists and serotonergic hallucinogens increase glutamate release, and it has been suggested that the glutamatergic system may represent a common final pathway for their psychotomimetic effects (Vollenweider \& Geyer, 2001). This view is consistent with the fact that both ketamine and psilocybin produce metabolic hyperfrontality (Vollenweider et al., 1997a; Vollenweider et al., 1997b), and have somewhat similar effects on perception and cognition (Vollenweider \& Geyer, 2001). Additional support for the convergence of serotonergic and glutamatergic systems is derived from the finding that the behavioral effects of hallucinogens are potentiated by co-administration of NMDA antagonists (Dall'Olio et al., 1999; Winter et al., 2000; Winter et al., 2004; Zhang \& Marek, 2008). Finally, 
evidence has emerged that $\mathrm{mGlu}_{2}$ and 5- $\mathrm{HT}_{2 \mathrm{~A}}$ receptors are co-localized in cortical neurons where they may form functional complexes (Gonzalez-Maeso et al., 2008; Moreno et al., 2016).

\section{Conclusions and future directions}

As reviewed above, considerable evidence derived from converging methods suggests that schizophrenia patients display abnormalities in serotonergic function. Nevertheless, different approaches intended to measure identical biological markers frequently produced contradictory results (e.g, autoradiographic postmortem studies vs. PET studies). In particular, results from peripheral measures (CSF, platelets, blood, hormone response) often did not match findings based upon more central parameters of serotonin function (receptor density, brain levels of 5-HT and metabolites). Moreover, it was repeatedly shown that some alterations of the 5-HT system reported in schizophrenia patients could be explained by chronic treatment with antipsychotic drugs. Despite some methodological reservations and the many contradictory results, there is accumulating evidence that the $5-\mathrm{HT}_{1 \mathrm{~A}}$ and the $5-\mathrm{HT}_{2 \mathrm{~A}}$ receptor subtypes play an especially important role in schizophrenia. Postmortem studies and some PET data suggest that schizophrenia patients display an increase of 5$\mathrm{HT}_{1 \mathrm{~A}}$ and a decrease of 5- $\mathrm{HT}_{2 \mathrm{~A}}$ receptors especially in the PFC. Genetic variations in 5-HT receptors appear to contribute to the response to antipsychotic treatment. Hallucinogenic 5- $\mathrm{HT}_{2 \mathrm{~A}}$ agonists produce some schizophrenia-like symptoms and also mimic several endophenotypes of schizophrenia. In contrast, the hypothesis that a serotonergic action of mechanism is necessary for the claimed therapeutic superiority of the so-called atypical antipsychotics is not well supported by the data so far because a 5-HT antagonistic action seems to be not sufficient for an antipsychotic effect (at least on the level of large and heterogenous populations of schizophrenia patients). Nevertheless, 5- $\mathrm{HT}_{1 \mathrm{~A}}$ agonists and $5-\mathrm{HT}_{2 \mathrm{C}}$ antagonists may have some beneficial effects particularly on cognition and negative symptoms. Additionally, agents acting at other 5 -HT receptor subtypes $\left(5-\mathrm{HT}_{4}, 5-\mathrm{HT}_{6}, 5-\right.$ $\mathrm{HT}_{7}$ ) may have some pro-cognitive effects in schizophrenia patients.

The highly contradictory results regarding serotonergic alterations in schizophrenia might have two origins: (1) Alterations of the serotonin system are not sufficient to explain the full picture of schizophrenia. This view is supported by the fact that other transmitter systems (e.g., dopamine, GABA, glutamate, acetylcholine) and biochemical substrates (such as reelin, BDNF, synaptophysin, SNAP-25, and complexin 2) are also affected in schizophrenia patients. (2) Not all but only a subpopulation of the patients within the broad disease cluster of schizophrenia display changes in serotonin function. This assumption is supported by several studies showing that some patients better respond to serotonergic antipsychotic drugs than other patients, that some alterations of the 5-HT systems at baseline could predict treatment response, and that serotonergic challenges induce a broad range of reactions ranging from improvement to worsening of symptoms, pointing to substantial heterogeneity of central serotonergic activity. 
The 5-HT system is probably only one piece from an enigmatic mosaic of multiple causal factors underlying the group of schizophrenia spectrum disorders. Specific (poly)genetic variations might influence the illness, e.g., the expression of serotonin receptors during neurogenesis, and these changes could have an impact on later brain maturation and 5-HT function. But only in combination with further neurodevelopmental "hits", such as prenatal and postnatal infections, stressful events or drug use during pregnancy, obstetric complications, a stressful adolescence, or other critical life events, does the symptom pattern of a schizophreniform disorder arise.

Future studies should devote more attention to the demarcation of subpopulations of schizophrenia patients exhibiting specific changes of the 5-HT system, who could then be successfully treated with specific serotonergic drugs. These subpopulations should not only to be characterized by distinct biological markers but also by a more precise psychopathological description. Moreover, the behavioral consequences of genetic variations within the 5-HT system or of pharmacological manipulations of the system might help to better understand disturbed brain functions of schizophrenia patients. Finally, recent preclinical data suggest that also alterations in the interaction between the serotonin and the glutamate system might have an influence on the development and the symptoms of schizophrenia. These interactions should be further investigated in healthy humans and schizophrenia patients.

\section{Acknowledgments}

Dr. Geyer and Dr. Halberstadt were supported by grants from the National Institute on Drug Abuse (DA041336) and the National Institute of Mental Health (MH108653, MH42228) and by the Veterans Affairs VISN 22 Mental Illness Research, Education, and Clinical Center. Dr. Quednow was supported by the Deutsche Forschungsgemeinschaft (DFG, grant QU 218/1-1) and by the Nachwuchsförderungskredit of the University of Zurich during the first edition of this book chapter. 


\section{References}

Abbas, A.I., Hedlund, P.B., Huang, X.P., Tran, T.B., Meltzer, H.Y., \& Roth, B.L. (2009). Amisulpride is a potent 5-HT7 antagonist: relevance for antidepressant actions in vivo. Psychopharmacology (Berl), 205(1), 119-128.

Abdolmaleky, H.M., Yaqubi, S., Papageorgis, P., Lambert, A.W., Ozturk, S., Sivaraman, V., et al. (2011). Epigenetic dysregulation of HTR2A in the brain of patients with schizophrenia and bipolar disorder. Schizophr Res, 129(2-3), 183-190.

Abel, K.M., O'Keane, V., \& Murray, R.M. (1996). Enhancement of the prolactin response to d-fenfluramine in drug-naive schizophrenic patients. Br J Psychiatry, 168(1), 57-60.

Abi-Dargham, A., \& Krystal, J. (2000). Serotonin receptors as targets of antipsychotic medication. In M.S. Lidow (Ed.), Neurotransmitter Receptors in Actions of Antipsychotic Medications (pp. 79-107). Boca Raton, Florida: CRC Press LLC.

Abi-Dargham, A., Laruelle, M., Lipska, B., Jaskiw, G.E., Wong, D.T., Robertson, D.W., et al. (1993). Serotonin 5-HT3 receptors in schizophrenia: a postmortem study of the amygdala. Brain Res, 616(1-2), 53-57.

Abi-Saab, W., Seibyl, J.P., D'Souza, D.C., Karper, L.P., Gueorgueva, R., Abi-Dargham, A., et al. (2002). Ritanserin antagonism of m-chlorophenylpiperazine effects in neuroleptic-free schizophrenics patients: support for serotonin-2 receptor modulation of schizophrenia symptoms. Psychopharmacology (Berl), 162(1), 55-62.

Adams, B., \& Moghaddam, B. (1998). Corticolimbic dopamine neurotransmission is temporally dissociated from the cognitive and locomotor effects of phencyclidine. J Neurosci, 18(14), 5545-5554.

Adams, L.M., \& Geyer, M.A. (1982). LSD-induced alterations of locomotor patterns and exploration in rats. Psychopharmacology (Berl), 77(2), 179-185.

Adams, L.M., \& Geyer, M.A. (1985). A proposed animal model for hallucinogens based on LSD's effects on patterns of exploration in rats. Behav Neurosci, 99(5), 881-900.

Aghajanian, G.K., \& Marek, G.J. (1997). Serotonin induces excitatory postsynaptic potentials in apical dendrites of neocortical pyramidal cells. Neuropharmacology, 36(4-5), 589-599.

Akhondzadeh, S., Malek-Hosseini, M., Ghoreishi, A., Raznahan, M., \& Rezazadeh, S.A. (2008). Effect of ritanserin, a 5HT2A/2C antagonist, on negative symptoms of schizophrenia: a double-blind randomized placebo-controlled study. Prog Neuropsychopharmacol Biol Psychiatry, 32(8), 1879-1883.

Allen, N.C., Bagade, S., McQueen, M.B., Ioannidis, J.P., Kavvoura, F.K., Khoury, M.J., et al. (2008). Systematic metaanalyses and field synopsis of genetic association studies in schizophrenia: the SzGene database. Nat Genet, 40(7), 827-834.

Anand, A., Charney, D.S., Oren, D.A., Berman, R.M., Hu, X.S., Cappiello, A., et al. (2000). Attenuation of the neuropsychiatric effects of ketamine with lamotrigine: support for hyperglutamatergic effects of N-methyl-Daspartate receptor antagonists. Arch Gen Psychiatry, 57(3), 270-276.

Andree, T.H., Mikuni, M., Tong, C.Y., Koenig, J.I., \& Meltzer, H.Y. (1986). Differential effect of subchronic treatment with various neuroleptic agents on serotonin2 receptors in rat cerebral cortex. J Neurochem, 46(1), 191-197.

Angelopoulos, E.K., Markianos, M., Daskalopoulou, E.G., Hatzimanolis, J., \& Tzemos, J. (2002). Changes in central serotonergic function as a correlate of duration of illness in paranoid schizophrenia. Psychiatry Res, 110(1), 9-17.

Angrist, B.M., \& Gershon, S. (1970). The phenomenology of experimentally induced amphetamine psychosis--preliminary observations. Biol Psychiatry, 2(2), 95-107.

Arnold, S.E. (1999). Neurodevelopmental abnormalities in schizophrenia: insights from neuropathology. Dev Psychopathol, 11(3), 439-456.

Arnold, S.E., Hyman, B.T., Van Hoesen, G.W., \& Damasio, A.R. (1991). Some cytoarchitectural abnormalities of the entorhinal cortex in schizophrenia. Arch Gen Psychiatry, 48(7), 625-632.

Arnt, J., \& Skarsfeldt, T. (1998). Do novel antipsychotics have similar pharmacological characteristics? A review of the evidence. Neuropsychopharmacology, 18(2), 63-101.

Arora, R.C., \& Meltzer, H.Y. (1983). Effects of chlorpromazine on serotonin uptake in blood platelets. Psychiatry Res, 9(1), 23-28.

Arora, R.C., \& Meltzer, H.Y. (1991). Serotonin2 (5-HT2) receptor binding in the frontal cortex of schizophrenic patients. $J$ Neural Transm Gen Sect, 85(1), 19-29.

Arranz, B., Rosel, P., San, L., Ramirez, N., Duenas, R.M., Salavert, J., et al. (2007). Low baseline serotonin-2A receptors predict clinical response to olanzapine in first-episode schizophrenia patients. Psychiatry Res, 153(2), 103-109.

Arranz, B., Rosel, P., Sarro, S., Ramirez, N., Duenas, R., Cano, R., et al. (2003). Altered platelet serotonin 5-HT2A receptor density but not second messenger inositol trisphosphate levels in drug-free schizophrenic patients. Psychiatry Res, $118(2), 165-174$

Arranz, M.J., \& de Leon, J. (2007). Pharmacogenetics and pharmacogenomics of schizophrenia: a review of last decade of research. Mol Psychiatry, 12(8), 707-747.

Arvanov, V.L., Liang, X., Russo, A., \& Wang, R.Y. (1999). LSD and DOB: interaction with 5-HT2A receptors to inhibit NMDA receptor-mediated transmission in the rat prefrontal cortex. Eur J Neurosci, 11(9), 3064-3072.

Bantick, R.A., Deakin, J.F., \& Grasby, P.M. (2001). The 5-HT1A receptor in schizophrenia: a promising target for novel atypical neuroleptics? J Psychopharmacol, 15(1), 37-46.

Bantick, R.A., Montgomery, A.J., Bench, C.J., Choudhry, T., Malek, N., McKenna, P.J., et al. (2004). A positron emission tomography study of the 5-HT1A receptor in schizophrenia and during clozapine treatment. J Psychopharmacol, 18(3), 346-354.

Baou, M., Boumba, V.A., Petrikis, P., Rallis, G., Vougiouklakis, T., \& Mavreas, V. (2016). A review of genetic alterations in the serotonin pathway and their correlation with psychotic diseases and response to atypical antipsychotics. Schizophr Res, 170(1), 18-29.

Baumeister, A.A., \& Hawkins, M.F. (2004). The serotonin hypothesis of schizophrenia: a historical case study on the heuristic value of theory in clinical neuroscience. J Hist Neurosci, 13(3), 277-291. 
Beique, J.C., Imad, M., Mladenovic, L., Gingrich, J.A., \& Andrade, R. (2007). Mechanism of the 5-hydroxytryptamine 2A receptor-mediated facilitation of synaptic activity in prefrontal cortex. Proc Natl Acad Sci U S A, 104(23), 98709875.

Bennett, J.P., Jr., Enna, S.J., Bylund, D.B., Gillin, J.C., Wyatt, R.J., \& Snyder, S.H. (1979). Neurotransmitter receptors in frontal cortex of schizophrenics. Arch Gen Psychiatry, 36(9), 927-934.

Benneyworth, M.A., Xiang, Z., Smith, R.L., Garcia, E.E., Conn, P.J., \& Sanders-Bush, E. (2007). A selective positive allosteric modulator of metabotropic glutamate receptor subtype 2 blocks a hallucinogenic drug model of psychosis. Mol Pharmacol, 72(2), 477-484.

Beringer, K. (1923). Experimentelle Psychosen durch Mescalin. Z Gesamte Neurol Psychiatr, 84(1), 426-433.

Bertler, A., Carlsson, A., \& Rosengren, E. (1956). Release by reserpine of catechol amines from rabbits' hearts. Naturwissenschaften, 43(22), 521.

Bertolino, A., \& Weinberger, D.R. (1999). Proton magnetic resonance spectroscopy in schizophrenia. Eur J Radiol, 30(2), $132-141$

Bilder, R.M., Goldman, R.S., Volavka, J., Czobor, P., Hoptman, M., Sheitman, B., et al. (2002). Neurocognitive effects of clozapine, olanzapine, risperidone, and haloperidol in patients with chronic schizophrenia or schizoaffective disorder. Am J Psychiatry, 159(6), 1018-1028.

Bleich, A., Brown, S.L., Kahn, R., \& van Praag, H.M. (1988). The role of serotonin in schizophrenia. Schizophr Bull, 14(2), 297-315.

Bleich, A., Brown, S.L., \& van Praag, H.M. (1991). A serotonergic theory of schizophrenia. In S.L. Brown \& H.M. van Praag (Eds.), The Role of Serotonin in Psychiatric Disorders (Vol. 4, pp. 183-214). New York: Brunner/Mazel, Publishers.

Blin, O. (1999). A comparative review of new antipsychotics. Can J Psychiatry, 44(3), 235-244.

Bolino, F., Di Michele, V., Di Cicco, L., Manna, V., Daneluzzo, E., \& Casacchia, M. (1994). Sensorimotor gating and habituation evoked by electro-cutaneous stimulation in schizophrenia. Biol Psychiatry, 36(10), 670-679.

Bowers, M.B., Jr., \& Freedman, D.X. (1966). "Psychedelic" experiences in acute psychoses. Arch Gen Psychiatry, 15(3), 240-248.

Braff, D. (1985). Attention, habituation and information processing in psychiatric disorders. In B. Micheks, J. Cavenar, H. Brodie, A. Cooper, S. Guze, \& L. Judd (Eds.), Psychiatry (pp. 1-12). Philadelphia: Lippincott.

Braff, D.L., \& Geyer, M.A. (1980). Acute and chronic LSD effects on rat startle: data supporting an LSD--rat model of schizophrenia. Biol Psychiatry, 15(6), 909-916.

Braff, D.L., \& Geyer, M.A. (1990). Sensorimotor gating and schizophrenia. Human and animal model studies. Arch Gen Psychiatry, 47(2), 181-188.

Braff, D.L., Stone, C., Callaway, E., Geyer, M., Glick, I., \& Bali, L. (1978). Prestimulus effects on human startle reflex in normals and schizophrenics. Psychophysiology, 15(4), 339-343.

Breier, A. (1995). Serotonin, schizophrenia and antipsychotic drug action. Schizophr Res, 14(3), 187-202.

Breier, A., Kirkpatrick, B., \& Buchanan, R.W. (1993). Clozapine attenuates meta-chlorophenylpiperazine (mCPP)-induced plasma cortisol increases in schizophrenia. Biol Psychiatry, 34(7), 492-494.

Brodie, B.A., Shore, P.A., \& Pletscher, A. (1956). Serotonin-releasing activity limited to Rauwolfia alkaloids with tranquilizing action. Science, 123(3205), 992-993.

Brodie, B.B., Pletscher, A., \& Shore, P.A. (1955). Evidence that serotonin has a role in brain function. Science, 122(3177), 968.

Bromet, E.J., \& Fennig, S. (1999). Epidemiology and natural history of schizophrenia. Biol Psychiatry, 46(7), 871-881.

Buchanan, R.W. (1995). Clozapine: efficacy and safety. Schizophr Bull, 21(4), 579-591.

Buchanan, R.W., Breier, A., Kirkpatrick, B., Ball, P., \& Carpenter, W.T., Jr. (1998). Positive and negative symptom response to clozapine in schizophrenic patients with and without the deficit syndrome. Am J Psychiatry, 155(6), 751-760.

Burnet, P.W., Chen, C.P., McGowan, S., Franklin, M., \& Harrison, P.J. (1996a). The effects of clozapine and haloperidol on serotonin-1 A, -2A and -2C receptor gene expression and serotonin metabolism in the rat forebrain. Neuroscience, 73(2), 531-540.

Burnet, P.W., Eastwood, S.L., \& Harrison, P.J. (1996b). 5-HT1A and 5-HT2A receptor mRNAs and binding site densities are differentially altered in schizophrenia. Neuropsychopharmacology, 15(5), 442-455.

Canu, E., Agosta, F., \& Filippi, M. (2015). A selective review of structural connectivity abnormalities of schizophrenic patients at different stages of the disease. Schizophr Res, 161(1), 19-28.

Carlsson, A. (1959). The occurrence, distribution and physiological role of catecholamines in the nervous system. Pharmacol Rev, 11(2, Part 2), 490-493.

Carlsson, A. (1988). The current status of the dopamine hypothesis of schizophrenia. Neuropsychopharmacology, 1(3), 179186.

Carlsson, A. (1995). Neurocircuitries and neurotransmitter interactions in schizophrenia. Int Clin Psychopharmacol, 10 Suppl 3, 21-28.

Carlsson, A., \& Lindqvist, M. (1963). Effect of chlorpromazine or haloperidol on formation of 3-methoxytyramine and normetanephrine in mouse brain. Acta Pharmacol Toxicol (Copenh), 20, 140-144.

Carlsson, A., Lindqvist, M., \& Magnusson, T. (1957). 3,4-Dihydroxyphenylalanine and 5-hydroxytryptophan as reserpine antagonists. Nature, 180(4596), 1200.

Carman, J., Peuskens, J., \& Vangeneugden, A. (1995). Risperidone in the treatment of negative symptoms of schizophrenia: a meta-analysis. Int Clin Psychopharmacol, 10(4), 207-213.

Carpenter, W.T., Jr., Conley, R.R., Buchanan, R.W., Breier, A., \& Tamminga, C.A. (1995). Patient response and resource management: another view of clozapine treatment of schizophrenia. Am J Psychiatry, 152(6), 827-832.

Chang, F.C., \& Fung, V.S. (2014). Clinical significance of pharmacogenomic studies in tardive dyskinesia associated with patients with psychiatric disorders. Pharmgenomics Pers Med, 7, 317-328. 
Cheah, S.Y., Lawford, B.R., Young, R.M., Morris, C.P., \& Voisey, J. (2017). mRNA Expression and DNA Methylation Analysis of Serotonin Receptor 2A (HTR2A) in the Human Schizophrenic Brain. Genes (Basel), 8(1).

Condrau, G. (1949). Klinische Erfahrungen an Geisteskranken mit Lysergsäure-diäthylamid. Acta Psychiat Neurol, $24,9-32$.

Cowen, P.J., Gadhvi, H., Gosden, B., \& Kolakowska, T. (1985). Responses of prolactin and growth hormone to L-tryptophan infusion: effects in normal subjects and schizophrenic patients receiving neuroleptics. Psychopharmacology (Berl), 86(1-2), 164-169.

Creese, I., Burt, D.R., \& Snyder, S.H. (1976). Dopamine receptor binding predicts clinical and pharmacological potencies of antischizophrenic drugs. Science, 192(4238), 481-483.

Crow, T.J. (1980a). Molecular pathology of schizophrenia: more than one disease process? Br Med J, 280(6207), 66-68.

Crow, T.J. (1980b). Positive and negative schizophrenic symptoms and the role of dopamine. Br J Psychiatry, 137, 383-386.

Crow, T.J., Baker, H.F., Cross, A.J., Joseph, M.H., Lofthouse, R., Longden, A., et al. (1979). Monoamine mechanisms in chronic schizophrenia: post-mortem neurochemical findings. Br J Psychiatry, 134, 249-256.

Cruz, D.A., Eggan, S.M., Azmitia, E.C., \& Lewis, D.A. (2004). Serotonin1A receptors at the axon initial segment of prefrontal pyramidal neurons in schizophrenia. Am J Psychiatry, 161(4), 739-742.

Csernansky, J.G., King, R.J., Faustman, W.O., Moses, J.A., Jr., Poscher, M.E., \& Faull, K.F. (1990). 5-HIAA in cerebrospinal fluid and deficit schizophrenic characteristics. Br J Psychiatry, 156, 501-507.

Da Silva Costa, V., Duchatelle, P., Boulouard, M., \& Dauphin, F. (2009). Selective 5-HT6 receptor blockade improves spatial recognition memory and reverses age-related deficits in spatial recognition memory in the mouse. Neuropsychopharmacology, 34(2), 488-500.

Dall'Olio, R., Gaggi, R., Bonfante, V., \& Gandolfi, O. (1999). The non-competitive NMDA receptor blocker dizocilpine potentiates serotonergic function. Behav Pharmacol, 10(1), 63-71.

de Jong, H. (1932). Die experimentelle Katatonie als vielfach vorkommende Reaktionsform des Zentralnervensystems. $Z$ Gesamte Neurol Psychiatr, 139(1), 468-499.

de Paulis, T. (2001). M-100907 (Aventis). Curr Opin Investig Drugs, 2(1), 123-132.

Dean, B. (2003). The cortical serotonin2A receptor and the pathology of schizophrenia: a likely accomplice. $J$ Neurochem, $85(1), 1-13$.

Dean, B., \& Hayes, W. (1996). Decreased frontal cortical serotonin2A receptors in schizophrenia. Schizophr Res, 21(3), 133139.

Dean, B., Hayes, W., Hill, C., \& Copolov, D. (1998). Decreased serotonin2A receptors in Brodmann's area 9 from schizophrenic subjects. A pathological or pharmacological phenomenon? Mol Chem Neuropathol, 34(2-3), 133145.

Dean, B., Hayes, W., Opeskin, K., Naylor, L., Pavey, G., Hill, C., et al. (1996). Serotonin2 receptors and the serotonin transporter in the schizophrenic brain. Behav Brain Res, 73(1-2), 169-175.

Dean, B., Hussain, T., Hayes, W., Scarr, E., Kitsoulis, S., Hill, C., et al. (1999a). Changes in serotonin2A and GABA(A) receptors in schizophrenia: studies on the human dorsolateral prefrontal cortex. J Neurochem, 72(4), 1593-1599.

Dean, B., Opeskin, K., Pavey, G., Naylor, L., Hill, C., Keks, N., et al. (1995). [3H]paroxetine binding is altered in the hippocampus but not the frontal cortex or caudate nucleus from subjects with schizophrenia. J Neurochem, 64(3), 1197-1202.

Dean, B., Pavey, G., Thomas, D., \& Scarr, E. (2006). Cortical serotonin7, 1D and 1F receptors: effects of schizophrenia, suicide and antipsychotic drug treatment. Schizophr Res, 88(1-3), 265-274.

Dean, B., Tomaskovic-Crook, E., Opeskin, K., Keks, N., \& Copolov, D. (1999b). No change in the density of the serotonin1A receptor, the serotonin4 receptor or the serotonin transporter in the dorsolateral prefrontal cortex from subjects with schizophrenia. Neurochem Int, 34(2), 109-115.

DeLisi, L.E., Wise, C.D., Bridge, T.P., Rosenblatt, J.E., Wagner, R.L., Morihisa, J., et al. (1981). A probable neuroleptic effect on platelet monoamine oxidase in chronic schizophrenic patients. Psychiatry Res, 4(1), 95-107.

DeVeaugh-Geiss, J., McBain, S., Cooksey, P., \& Bell, J.M. (1992). The effects of a novel 5-HT3 anatgonist, ondansetron, in schizophrenia. In H.Y. Meltzer (Ed.), Novel Antipsychotic Drugs (pp. 225-232). New York: Raven Press.

Di Matteo, V., Di Giovanni, G., Di Mascio, M., \& Esposito, E. (1998). Selective blockade of serotonin2C/2B receptors enhances dopamine release in the rat nucleus accumbens. Neuropharmacology, 37(2), 265-272.

Dittrich, A. (1998). The standardized psychometric assessment of altered states of consciousness (ASCs) in humans. Pharmacopsychiatry, 31 Suppl 2, 80-84.

Dulawa, S.C., \& Geyer, M.A. (2000). Effects of strain and serotonergic agents on prepulse inhibition and habituation in mice. Neuropharmacology, 39(11), 2170-2179.

Dunlop, J., Watts, S.W., Barrett, J.E., Coupet, J., Harrison, B., Mazandarani, H., et al. (2011). Characterization of Vabicaserin (SCA-136), a Selective 5-Hydroxytryptamine 2C Receptor Agonist. Journal of Pharmacology and Experimental Therapeutics, 337(3), 673-680.

East, S.Z., Burnet, P.W., Leslie, R.A., Roberts, J.C., \& Harrison, P.J. (2002). 5-HT6 receptor binding sites in schizophrenia and following antipsychotic drug administration: autoradiographic studies with [125I]SB-258585. Synapse, 45(3), 191-199.

Erritzoe, D., Rasmussen, H., Kristiansen, K.T., Frokjaer, V.G., Haugbol, S., Pinborg, L., et al. (2008). Cortical and subcortical 5-HT2A receptor binding in neuroleptic-naive first-episode schizophrenic patients. Neuropsychopharmacology, 33(10), 2435-2441.

Ertugrul, A., Ucar, G., Basar, K., Demir, B., Yabanoglu, S., \& Ulug, B. (2007). Influence of clozapine on platelet serotonin, monoamine oxidase and plasma serotonin levels. Psychiatry Res, 149(1-3), 49-57.

Falkai, P., Schneider-Axmann, T., \& Honer, W.G. (2000). Entorhinal cortex pre-alpha cell clusters in schizophrenia: quantitative evidence of a developmental abnormality. Biol Psychiatry, 47(11), 937-943.

Faraone, S.V., Chen, W.J., Goldstein, J.M., \& Tsuang, M.T. (1994). Gender differences in age at onset of schizophrenia. $B r J$ Psychiatry, 164(5), 625-629. 
Farley, I.J., Shannak, K.S., \& Hornykiewicz, O. (1980). Brain monoamine changes in chronic paranoid schizophrenia and their possible relation to increased receptor sensitivity. In G. Pepeu, M.J. Kuhar, \& S.J. Enna (Eds.), Receptors for Neurotransmitters and Peptides (Vol. 427-33). New York: Raven Press.

Fitzsimmons, J., Kubicki, M., \& Shenton, M.E. (2013). Review of functional and anatomical brain connectivity findings in schizophrenia. Curr Opin Psychiatry, 26(2), 172-187.

Fleischhaker, C., Schulz, E., \& Remschmidt, H. (1998). Biogenic amines as predictors of response to clozapine treatment in early-onset schizophrenia. J Psychiatr Res, 32(5), 325-333.

Fone, K.C. (2008). An update on the role of the 5-hydroxytryptamine6 receptor in cognitive function. Neuropharmacology, 55(6), 1015-1022.

Fornito, A., \& Bullmore, E.T. (2015). Reconciling abnormalities of brain network structure and function in schizophrenia. Curr Opin Neurobiol, 30, 44-50.

Frankle, W.G., Lerma, J., \& Laruelle, M. (2003). The synaptic hypothesis of schizophrenia. Neuron, 39(2), 205-216.

Frankle, W.G., Lombardo, I., Kegeles, L.S., Slifstein, M., Martin, J.H., Huang, Y., et al. (2006). Serotonin 1A receptor availability in patients with schizophrenia and schizo-affective disorder: a positron emission tomography imaging study with [11C]WAY 100635. Psychopharmacology (Berl), 189(2), 155-164.

Frankle, W.G., Narendran, R., Huang, Y., Hwang, D.R., Lombardo, I., Cangiano, C., et al. (2005). Serotonin transporter availability in patients with schizophrenia: a positron emission tomography imaging study with [11C]DASB. Biol Psychiatry, 57(12), 1510-1516.

Freedman, B., \& Chapman, L.J. (1973). Early subjective experience in schizophrenic episodes. J Abnorm Psychol, 82(1), 4654.

Friston, K.J., \& Frith, C.D. (1995). Schizophrenia: a disconnection syndrome? Clin Neurosci, 3(2), 89-97.

Gaddum, J.H. (1953). Antagonism between lysergic acid diethylamide and 5-hydroxytryptamine. J Physiol, 121(1), 15P.

Gaddum, J.H., \& Hameed, K.A. (1954). Drugs which antagonize 5-hydroxytryptamine. Br J Pharmacol Chemother, 9(2), 240-248.

Gaster, L.M., \& King, F.D. (1997). Serotonin 5-HT3 and 5-HT4 receptor antagonists. Med Res Rev, 17(2), 163-214.

Gefvert, O., Lundberg, T., Wieselgren, I.M., Bergstrom, M., Langstrom, B., Wiesel, F., et al. (2001). D(2) and 5HT(2A) receptor occupancy of different doses of quetiapine in schizophrenia: a PET study. Eur Neuropsychopharmacol, 11(2), 105-110.

Gewirtz, J.C., \& Marek, G.J. (2000). Behavioral evidence for interactions between a hallucinogenic drug and group II metabotropic glutamate receptors. Neuropsychopharmacology, 23(5), 569-576.

Geyer, M., \& Moghaddam, B. (2002). Animal models relevant to schizophrenia disorders. In D. K (Ed.), Neuropsychopharmacology: The Fifth Generation of Progress (pp. 689-701): Lippincott Williams \& Wilkins.

Geyer, M.A. (1998). Behavioral studies of hallucinogenic drugs in animals: implications for schizophrenia research. Pharmacopsychiatry, 31 Suppl 2, 73-79.

Geyer, M.A., \& Braff, D.L. (1982). Habituation of the Blink reflex in normals and schizophrenic patients. Psychophysiology, $19(1), 1-6$.

Geyer, M.A., \& Braff, D.L. (1987). Startle habituation and sensorimotor gating in schizophrenia and related animal models. Schizophr Bull, 13(4), 643-668.

Geyer, M.A., Krebs-Thomson, K., Braff, D.L., \& Swerdlow, N.R. (2001). Pharmacological studies of prepulse inhibition models of sensorimotor gating deficits in schizophrenia: a decade in review. Psychopharmacology (Berl), 156(2-3), 117-154.

Geyer, M.A., Petersen, L.R., Rose, G.J., Horwitt, D.D., Light, R.K., Adams, L.M., et al. (1978). The effects of lysergic acid diethylamide and mescaline-derived hallucinogens on sensory-integrative function: tactile startle. $J$ Pharmacol Exp Ther, 207(3), 837-847.

Geyer, M.A., \& Vollenweider, F.X. (2008). Serotonin research: contributions to understanding psychoses. Trends Pharmacol Sci, 29(9), 445-453.

Goldberg, T.E., Goldman, R.S., Burdick, K.E., Malhotra, A.K., Lencz, T., Patel, R.C., et al. (2007). Cognitive improvement after treatment with second-generation antipsychotic medications in first-episode schizophrenia: is it a practice effect? Arch Gen Psychiatry, 64(10), 1115-1122.

Goldstein, J.M., Tsuang, M.T., \& Faraone, S.V. (1989). Gender and schizophrenia: implications for understanding the heterogeneity of the illness. Psychiatry Res, 28(3), 243-253.

Gonzalez-Maeso, J., Ang, R.L., Yuen, T., Chan, P., Weisstaub, N.V., Lopez-Gimenez, J.F., et al. (2008). Identification of a serotonin/glutamate receptor complex implicated in psychosis. Nature, 452(7183), 93-97.

Gottesman, I. (1991). Schizophrenia genesis: The origin of madness. New York: W. H. Freeman.

Gottesman, I., \& Gould, T.D. (2003). The endophenotype concept in psychiatry: etymology and strategic intentions. Am J Psychiatry, 160(4), 636-645.

Gouzoulis-Mayfrank, E., Habermeyer, E., Hermle, L., Steinmeyer, A.M., Kunert, H.J., \& Sass, H. (1998a). Hallucinogenic drug induced states resemble acute endogenous psychoses: Results of an empirical study. Eur Psychiatry, 13, 399406.

Gouzoulis-Mayfrank, E., Hermle, L., Thelen, B., \& Sass, H. (1998b). History, rationale and potential of human experimental hallucinogenic drug research in psychiatry. Pharmacopsychiatry, 31 Suppl 2, 63-68.

Gouzoulis-Mayfrank, E., Thelen, B., Habermeyer, E., Kunert, H.J., Kovar, K.A., Lindenblatt, H., et al. (1999). Psychopathological, neuroendocrine and autonomic effects of 3,4-methylenedioxyethylamphetamine (MDE), psilocybin and d-methamphetamine in healthy volunteers. Results of an experimental double-blind placebocontrolled study. Psychopharmacology (Berl), 142(1), 41-50.

Gray, J.A., \& Roth, B.L. (2007). Molecular targets for treating cognitive dysfunction in schizophrenia. Schizophr Bull, 33(5), $1100-1119$.

Gray, L., Scarr, E., \& Dean, B. (2006). Serotonin 1a receptor and associated G-protein activation in schizophrenia and bipolar disorder. Psychiatry Res, 143(2-3), 111-120. 
Green, M.F. (1996). What are the functional consequences of neurocognitive deficits in schizophrenia? Am J Psychiatry, 153(3), 321-330.

Gressier, F., Porcelli, S., Calati, R., \& Serretti, A. (2016). Pharmacogenetics of clozapine response and induced weight gain: A comprehensive review and meta-analysis. Eur Neuropsychopharmacol, 26(2), 163-185.

Guidotti, A., Pesold, C., \& Costa, E. (2000). New neurochemical markers for psychosis: a working hypothesis of their operation. Neurochem Res, 25(9-10), 1207-1218.

Gurevich, E.V., \& Joyce, J.N. (1997). Alterations in the cortical serotonergic system in schizophrenia: a postmortem study. Biol Psychiatry, 42(7), 529-545.

Haertzen, C.A., Hill, H.E., \& Belleville, R.E. (1963). Development of the Addiction Research Center Inventory (Arci): Selection of Items That Are Sensitive to the Effects of Various Drugs. Psychopharmacologia, 4, 155-166.

Halberstadt, A.L. (1995). The phencyclidine-glutamate model of schizophrenia. Clin Neuropharmacol, 18(3), 237-249.

Halberstadt, A.L., \& Geyer, M.A. (2011). Multiple receptors contribute to the behavioral effects of indoleamine hallucinogens. Neuropharmacology, 61(3), 364-381.

Harmar, A.J., Hills, R.A., Rosser, E.M., Jones, M., Buneman, O.P., Dunbar, D.R., et al. (2009). IUPHAR-DB: the IUPHAR database of G protein-coupled receptors and ion channels. Nucleic Acids Res, 37(Database issue), D680-685.

Harrison, P.J. (1999a). Neurochemical alterations in schizophrenia affecting the putative receptor targets of atypical antipsychotics. Focus on dopamine (D1, D3, D4) and 5-HT2a receptors. Br J Psychiatry Suppl(38), 12-22.

Harrison, P.J. (1999b). The neuropathology of schizophrenia. A critical review of the data and their interpretation. Brain, 122 (Pt 4), 593-624.

Harrison, P.J. (2004). The hippocampus in schizophrenia: a review of the neuropathological evidence and its pathophysiological implications. Psychopharmacology (Berl), 174(1), 151-162.

Harrison, P.J., \& Eastwood, S.L. (2001). Neuropathological studies of synaptic connectivity in the hippocampal formation in schizophrenia. Hippocampus, 11(5), 508-519.

Harrison, P.J., \& Owen, M.J. (2003). Genes for schizophrenia? Recent findings and their pathophysiological implications. Lancet, 361(9355), 417-419.

Harrison, P.J., \& Weinberger, D.R. (2005). Schizophrenia genes, gene expression, and neuropathology: on the matter of their convergence. Mol Psychiatry, 10(1), 40-68; image 45.

Hashimoto, T., Nishino, N., Nakai, H., \& Tanaka, C. (1991). Increase in serotonin 5-HT1A receptors in prefrontal and temporal cortices of brains from patients with chronic schizophrenia. Life Sci, 48(4), 355-363.

Hasler, F., Grimberg, U., Benz, M.A., Huber, T., \& Vollenweider, F.X. (2004). Acute psychological and physiological effects of psilocybin in healthy humans: a double-blind, placebo-controlled dose-effect study. Psychopharmacology (Berl), 172(2), 145-156.

Hasler, F., Quednow, B.B., Treyer, V., Schubiger, P.A., Buck, A., \& Vollenweider, F.X. (2009). Role of prefrontal serotonin2A receptors in self-experience during psilocybin-induced altered states. Neuropsychobiology, 59(2), 60.

Hatcher, P.D., Brown, V.J., Tait, D.S., Bate, S., Overend, P., Hagan, J.J., et al. (2005). 5-HT6 receptor antagonists improve performance in an attentional set shifting task in rats. Psychopharmacology (Berl), 181(2), 253-259.

Healy, D. (2002). The Creation of Psychopharmacology. Cambridge, Mass.: Harvard University Press.

Hermle, L., Funfgeld, M., Oepen, G., Botsch, H., Borchardt, D., Gouzoulis, E., et al. (1992). Mescaline-induced psychopathological, neuropsychological, and neurometabolic effects in normal subjects: experimental psychosis as a tool for psychiatric research. Biol Psychiatry, 32(11), 976-991.

Hermle, L., \& Kraehenmann, R. (2018). Experimental Psychosis Research and Schizophrenia-Similarities and Dissimilarities in Psychopathology. Curr Top Behav Neurosci, 36, 313-332.

Hernandez, I., \& Sokolov, B.P. (1997). Abnormal expression of serotonin transporter mRNA in the frontal and temporal cortex of schizophrenics. Mol Psychiatry, 2(1), 57-64.

Hernandez, I., \& Sokolov, B.P. (2000). Abnormalities in 5-HT2A receptor mRNA expression in frontal cortex of chronic elderly schizophrenics with varying histories of neuroleptic treatment. J Neurosci Res, 59(2), 218-225.

Hollister, L.E. (1962). Drug-induced psychoses and schizophrenic reactions: a critical comparison. Ann N Y Acad Sci, 96, 8092.

Holzman, P., \& Matthysse, S. (1990). The genetics of schizophrenia: A review. Psychol Sci, 1, 279-285.

Honer, W., \& Young, C. (2004). Presynaptic proteins and schizophrenia. In J. Smythies (Ed.), Disorders of Synaptic Plasticity and Schizophrenia (pp. 175-201). Amsterdam: Elsevier.

Hoshino, Y., Kaneko, M., Kumashiro, H., \& Tachibana, R. (1985). Endocrinological function in schizophrenic patients under haloperidol treatment: plasma PRL, HGH and 5HT levels after L-5HTP loading. Folia Psychiatr Neurol Jpn, 39(1), 25-31.

Hsiao, J.K., Potter, W.Z., Agren, H., Owen, R.R., \& Pickar, D. (1993). Clinical investigation of monoamine neurotransmitter interactions. Psychopharmacology (Berl), 112(1 Suppl), S76-84.

Hurlemann, R., Boy, C., Meyer, P.T., Scherk, H., Wagner, M., Herzog, H., et al. (2005). Decreased prefrontal 5-HT2A receptor binding in subjects at enhanced risk for schizophrenia. Anat Embryol (Berl), 210(5-6), 519-523.

Hurlemann, R., Matusch, A., Kuhn, K.U., Berning, J., Elmenhorst, D., Winz, O., et al. (2008). 5-HT2A receptor density is decreased in the at-risk mental state. Psychopharmacology (Berl), 195(4), 579-590.

Idris, N.F., Repeto, P., Neill, J.C., \& Large, C.H. (2005). Investigation of the effects of lamotrigine and clozapine in improving reversal-learning impairments induced by acute phencyclidine and D-amphetamine in the rat. Psychopharmacology (Berl), 179(2), 336-348.

Impagnatiello, F., Guidotti, A.R., Pesold, C., Dwivedi, Y., Caruncho, H., Pisu, M.G., et al. (1998). A decrease of reelin expression as a putative vulnerability factor in schizophrenia. Proc Natl Acad Sci U S A, 95(26), 15718-15723.

Iqbal, N., Asnis, G.M., Wetzler, S., Kahn, R.S., Kay, S.R., \& van Praag, H.M. (1991). The MCPP challenge test in schizophrenia: hormonal and behavioral responses. Biol Psychiatry, 30(8), 770-778.

Iqbal, N., \& van Praag, H.M. (1995). The role of serotonin in schizophrenia. Eur Neuropsychopharmacol, 5 Suppl, 11-23. 
Ito, H., Nyberg, S., Halldin, C., Lundkvist, C., \& Farde, L. (1998). PET imaging of central 5-HT2A receptors with carbon11-MDL 100,907. J Nucl Med, 39(1), 208-214.

Jacobsen, L.K., Frazier, J.A., Malhotra, A.K., Karoum, F., McKenna, K., Gordon, C.T., et al. (1997). Cerebrospinal fluid monoamine metabolites in childhood-onset schizophrenia. Am J Psychiatry, 154(1), 69-74.

Jakob, H., \& Beckmann, H. (1986). Prenatal developmental disturbances in the limbic allocortex in schizophrenics. J Neural Transm, 65(3-4), 303-326.

Javitt, D.C., \& Zukin, S.R. (1991). Recent advances in the phencyclidine model of schizophrenia. Am J Psychiatry, 148(10), 1301-1308.

Jennings, W.S., Jr., Schulz, S.C., Narasimhachari, N., Hamer, R.M., \& Friedel, R.O. (1985). Brain ventricular size and CSF monoamine metabolites in an adolescent inpatient population. Psychiatry Res, 16(2), 87-94.

Jentsch, J.D., \& Roth, R.H. (1999). The neuropsychopharmacology of phencyclidine: from NMDA receptor hypofunction to the dopamine hypothesis of schizophrenia. Neuropsychopharmacology, 20(3), 201-225.

Jessen, F., Scherk, H., Traber, F., Theyson, S., Berning, J., Tepest, R., et al. (2006). Proton magnetic resonance spectroscopy in subjects at risk for schizophrenia. Schizophr Res, 87(1-3), 81-88.

Joseph, M.H., Owen, F., Baker, H.F., \& Bourne, R.C. (1977). Platelet serotonin concentration and monoamine oxidase activity in unmedicated chronic schizophrenic and in schizoaffective patients. Psychol Med, 7(1), 159-162.

Joyce, J.N., Shane, A., Lexow, N., Winokur, A., Casanova, M.F., \& Kleinman, J.E. (1993). Serotonin uptake sites and serotonin receptors are altered in the limbic system of schizophrenics. Neuropsychopharmacology, 8(4), 315-336.

Kahn, R.S., Davidson, M., Knott, P., Stern, R.G., Apter, S., \& Davis, K.L. (1993a). Effect of neuroleptic medication on cerebrospinal fluid monoamine metabolite concentrations in schizophrenia. Serotonin-dopamine interactions as a target for treatment. Arch Gen Psychiatry, 50(8), 599-605.

Kahn, R.S., Davidson, M., Siever, L., Gabriel, S., Apter, S., \& Davis, K.L. (1993b). Serotonin function and treatment response to clozapine in schizophrenic patients. Am J Psychiatry, 150(9), 1337-1342.

Kahn, R.S., Davidson, M., Siever, L.J., Sevy, S., \& Davis, K.L. (1994). Clozapine treatment and its effect on neuroendocrine responses induced by the serotonin agonist, m-chlorophenylpiperazine. Biol Psychiatry, 35(12), 909-912.

Kahn, R.S., Siever, L.J., Gabriel, S., Amin, F., Stern, R.G., DuMont, K., et al. (1992). Serotonin function in schizophrenia: effects of meta-chlorophenylpiperazine in schizophrenic patients and healthy subjects. Psychiatry Res, 43(1), 1-12.

Kahn, R.S., \& Wetzler, S. (1991). m-Chlorophenylpiperazine as a probe of serotonin function. Biol Psychiatry, 30(11), 11391166 .

Kane, J., Honigfeld, G., Singer, J., \& Meltzer, H. (1988). Clozapine for the treatment-resistant schizophrenic. A double-blind comparison with chlorpromazine. Arch Gen Psychiatry, 45(9), 789-796.

Kapur, S., \& Seeman, P. (2001). Does fast dissociation from the dopamine d(2) receptor explain the action of atypical antipsychotics?: A new hypothesis. Am J Psychiatry, 158(3), 360-369.

Kapur, S., Zipursky, R., Jones, C., Remington, G., \& Houle, S. (2000). Relationship between dopamine D(2) occupancy, clinical response, and side effects: a double-blind PET study of first-episode schizophrenia. Am J Psychiatry, 157(4), 514-520.

Kapur, S., Zipursky, R.B., Remington, G., Jones, C., DaSilva, J., Wilson, A.A., et al. (1998). 5-HT2 and D2 receptor occupancy of olanzapine in schizophrenia: a PET investigation. Am J Psychiatry, 155(7), 921-928.

Kasper, S., Tauscher, J., Kufferle, B., Barnas, C., Pezawas, L., \& Quiner, S. (1999). Dopamine- and serotonin-receptors in schizophrenia: results of imaging-studies and implications for pharmacotherapy in schizophrenia. Eur Arch Psychiatry Clin Neurosci, 249 Suppl 4, 83-89.

Keefe, R.S., Bilder, R.M., Davis, S.M., Harvey, P.D., Palmer, B.W., Gold, J.M., et al. (2007). Neurocognitive effects of antipsychotic medications in patients with chronic schizophrenia in the CATIE Trial. Arch Gen Psychiatry, 64(6), 633-647.

Keeler, M.H. (1965). Similarity of schizophrenia and the psilocybin syndrome as determined by objective methods. Int $J$ Neuropsychiatry, 1(6), 630-634.

Kern, R.S., Green, M.F., Marshall, B.D., Jr., Wirshing, W.C., Wirshing, D., McGurk, S.R., et al. (1999). Risperidone versus haloperidol on secondary memory: can newer medications aid learning? Schizophr Bull, 25(2), 223-232.

Key, B.J. (1964). The effect of LSD-25 on the interaction between conditioned and non-conditioned stimuli in a simple avoidance situation. Psychopharmacologia, 6(5), 319-326.

Kim, J.H., Kim, J.H., Son, Y.D., Joo, Y.H., Lee, S.Y., Kim, H.K., et al. (2017). Altered interregional correlations between serotonin transporter availability and cerebral glucose metabolism in schizophrenia: A high-resolution PET study using [(11)C]DASB and [(18)F]FDG. Schizophr Res, 182, 55-65.

Kim, J.H., Son, Y.D., Kim, J.H., Choi, E.J., Lee, S.Y., Lee, J.E., et al. (2015). Serotonin transporter availability in thalamic subregions in schizophrenia: a study using 7.0-T MRI with [(11)C]DASB high-resolution PET. Psychiatry Res, 231(1), 50-57.

Klodzinska, A., Bijak, M., Tokarski, K., \& Pilc, A. (2002). Group II mGlu receptor agonists inhibit behavioural and electrophysiological effects of DOI in mice. Pharmacol Biochem Behav, 73(2), 327-332.

Knauer, A., \& Maloney, W.J.M.A. (1913). A prelimnary note on the psychic action of mescaline, with special reference to the mechanism of visual hallucinations. J Nerv Ment Dis, 40(7), 425-436.

Kolakowska, T., Cowen, P.J., \& Murdock, P. (1987). Endocrine responses to tryptophan infusion in schizophrenic patients treated with neuroleptics. Psychoneuroendocrinology, 12(3), 193-202.

Koreen, A.R., Lieberman, J.A., Alvir, J., \& Chakos, M. (1997). The behavioral effect of m-chlorophenylpiperazine (mCPP) and methylphenidate in first-episode schizophrenia and normal controls. Neuropsychopharmacology, 16(1), 61-68.

Kouzmenko, A.P., Hayes, W.L., Pereira, A.M., Dean, B., Burnet, P.W., \& Harrison, P.J. (1997). 5-HT2A receptor polymorphism and steady state receptor expression in schizophrenia. Lancet, 349(9068), 1815.

Krystal, J.H., Karper, L.P., Seibyl, J.P., Freeman, G.K., Delaney, R., Bremner, J.D., et al. (1994). Subanesthetic effects of the noncompetitive NMDA antagonist, ketamine, in humans. Psychotomimetic, perceptual, cognitive, and neuroendocrine responses. Arch Gen Psychiatry, 51(3), 199-214. 
Krystal, J.H., Seibyl, J.P., Price, L.H., Woods, S.W., Heninger, G.R., Aghajanian, G.K., et al. (1993). mChlorophenylpiperazine effects in neuroleptic-free schizophrenic patients. Evidence implicating serotonergic systems in the positive symptoms of schizophrenia. Arch Gen Psychiatry, 50(8), 624-635.

Lambe, E.K., Goldman-Rakic, P.S., \& Aghajanian, G.K. (2000). Serotonin induces EPSCs preferentially in layer V pyramidal neurons of the frontal cortex in the rat. Cereb Cortex, 10(10), 974-980.

Laruelle, M., Abi-Dargham, A., Casanova, M.F., Toti, R., Weinberger, D.R., \& Kleinman, J.E. (1993a). Selective abnormalities of prefrontal serotonergic receptors in schizophrenia. A postmortem study. Arch Gen Psychiatry, 50(10), 810-818.

Laruelle, M., Abi-Dargham, A., Gil, R., Kegeles, L., \& Innis, R. (1999). Increased dopamine transmission in schizophrenia: relationship to illness phases. Biol Psychiatry, 46(1), 56-72.

Laruelle, M., Abi-Dargham, A., van Dyck, C., Gil, R., D'Souza, D.C., Krystal, J., et al. (2000). Dopamine and serotonin transporters in patients with schizophrenia: an imaging study with [(123)I]beta-CIT. Biol Psychiatry, 47(5), 371379.

Laruelle, M., Baldwin, R.M., Malison, R.T., Zea-Ponce, Y., Zoghbi, S.S., al-Tikriti, M.S., et al. (1993b). SPECT imaging of dopamine and serotonin transporters with [123I]beta-CIT: pharmacological characterization of brain uptake in nonhuman primates. Synapse, 13(4), 295-309.

Leach, P.T., Cordero, K.A., \& Gould, T.J. (2013). The effects of acute nicotine, chronic nicotine, and withdrawal from chronic nicotine on performance of a cued appetitive response. Behav Neurosci, 127(2), 303-310.

Lerer, B., Ran, A., Blacker, M., Silver, H., Weller, M.P., Drummer, D., et al. (1988). Neuroendocrine responses in chronic schizophrenia. Evidence for serotonergic dysfunction. Schizophr Res, 1(6), 405-410.

Lerond, J., Lothe, A., Ryvlin, P., Bouvard, S., d'Amato, T., Ciumas, C., et al. (2013). Effects of aripiprazole, risperidone, and olanzapine on 5-HT1A receptors in patients with schizophrenia. J Clin Psychopharmacol, 33(1), 84-89.

Leucht, S. (2004). Amisulpride a selective dopamine antagonist and atypical antipsychotic: results of a meta-analysis of randomized controlled trials. Int J Neuropsychopharmacol, 7 Suppl 1, S15-20.

Leucht, S., Cipriani, A., Spineli, L., Mavridis, D., Orey, D., Richter, F., et al. (2013). Comparative efficacy and tolerability of 15 antipsychotic drugs in schizophrenia: a multiple-treatments meta-analysis. Lancet, 382(9896), 951-962.

Leucht, S., Corves, C., Arbter, D., Engel, R.R., Li, C., \& Davis, J.M. (2009). Second-generation versus first-generation antipsychotic drugs for schizophrenia: a meta-analysis. Lancet, 373(9657), 31-41.

Leucht, S., Pitschel-Walz, G., Abraham, D., \& Kissling, W. (1999). Efficacy and extrapyramidal side-effects of the new antipsychotics olanzapine, quetiapine, risperidone, and sertindole compared to conventional antipsychotics and placebo. A meta-analysis of randomized controlled trials. Schizophr Res, 35(1), 51-68.

Leucht, S., Pitschel-Walz, G., Engel, R.R., \& Kissling, W. (2002). Amisulpride, an unusual "atypical" antipsychotic: a metaanalysis of randomized controlled trials. Am J Psychiatry, 159(2), 180-190.

Lewine, R.R., Risch, S.C., Risby, E., Stipetic, M., Jewart, R.D., Eccard, M., et al. (1991). Lateral ventricle-brain ratio and balance between CSF HVA and 5-HIAA in schizophrenia. Am J Psychiatry, 148(9), 1189-1194.

Lewis, D.A. (2000). GABAergic local circuit neurons and prefrontal cortical dysfunction in schizophrenia. Brain Res Brain Res Rev, 31(2-3), 270-276.

Lewis, R., Kapur, S., Jones, C., DaSilva, J., Brown, G.M., Wilson, A.A., et al. (1999). Serotonin 5-HT2 receptors in schizophrenia: a PET study using [18F]setoperone in neuroleptic-naive patients and normal subjects. Am J Psychiatry, 156(1), 72-78.

Liddle, P.F. (2000). Cognitive impairment in schizophrenia: its impact on social functioning. Acta Psychiatr Scand Suppl, 400, 11-16.

Lidow, M.S. (2000). General overview of contemporary antipsychotic medications. In M.S. Lidow (Ed.), Neurotransmitter Receptors in Actions of Antipsychotic Medications (pp. 17-29). Boca Raton, Florida: CRC Press LLC.

Lieberman, J.A., Kane, J.M., Safferman, A.Z., Pollack, S., Howard, A., Szymanski, S., et al. (1994). Predictors of response to clozapine. J Clin Psychiatry, 55 Suppl B, 126-128.

Lieberman, J.A., Mailman, R.B., Duncan, G., Sikich, L., Chakos, M., Nichols, D.E., et al. (1998). Serotonergic basis of antipsychotic drug effects in schizophrenia. Biol Psychiatry, 44(11), 1099-1117.

Liu, J., Ogden, A., Comery, T.A., Spiros, A., Roberts, P., \& Geerts, H. (2014). Prediction of Efficacy of Vabicaserin, a 5HT2C Agonist, for the Treatment of Schizophrenia Using a Quantitative Systems Pharmacology Model. CPT: Pharmacometrics \& Systems Pharmacology, 3(4), e111.

Losonczy, M.F., Song, I.S., Mohs, R.C., Small, N.A., Davidson, M., Johns, C.A., et al. (1986). Correlates of lateral ventricular size in chronic schizophrenia, I: Behavioral and treatment response measures. Am J Psychiatry, 143(8), 976-981.

Ludewig, K., Geyer, M.A., \& Vollenweider, F.X. (2003). Deficits in prepulse inhibition and habituation in never-medicated, first-episode schizophrenia. Biol Psychiatry, 54(2), 121-128.

Mackay, A.V., Doble, A., Bird, E.D., Spokes, E.G., Quik, M., \& Iversen, L.L. (1978). 3H-Spiperone binding in normal and schizophrenic post-mortem human brain. Life Sci, 23(5), 527-532.

Maes, M., \& Meltzer, H.Y. (1996). Effects of meta-chlorophenylpiperazine on neuroendocrine and behavioral responses in male schizophrenic patients and normal volunteers. Psychiatry Res, 64(3), 147-159.

Mamo, D., Graff, A., Mizrahi, R., Shammi, C.M., Romeyer, F., \& Kapur, S. (2007). Differential effects of aripiprazole on $\mathrm{D}(2), 5-\mathrm{HT}(2)$, and 5-HT(1A) receptor occupancy in patients with schizophrenia: a triple tracer PET study. Am J Psychiatry, 164(9), 1411-1417.

Mamo, D., Kapur, S., Shammi, C.M., Papatheodorou, G., Mann, S., Therrien, F., et al. (2004). A PET study of dopamine D2 and serotonin 5-HT2 receptor occupancy in patients with schizophrenia treated with therapeutic doses of ziprasidone. Am J Psychiatry, 161(5), 818-825.

Marcos, B., Chuang, T.T., Gil-Bea, F.J., \& Ramirez, M.J. (2008). Effects of 5-HT6 receptor antagonism and cholinesterase inhibition in models of cognitive impairment in the rat. Br J Pharmacol, 155(3), 434-440.

Marder, S.R., \& Meibach, R.C. (1994). Risperidone in the treatment of schizophrenia. Am J Psychiatry, 151(6), 825-835. 
Marek, G.J., Wright, R.A., Gewirtz, J.C., \& Schoepp, D.D. (2001). A major role for thalamocortical afferents in serotonergic hallucinogen receptor function in the rat neocortex. Neuroscience, 105(2), 379-392.

Marek, G.J., Wright, R.A., Schoepp, D.D., Monn, J.A., \& Aghajanian, G.K. (2000). Physiological antagonism between 5hydroxytryptamine(2A) and group II metabotropic glutamate receptors in prefrontal cortex. J Pharmacol Exp Ther, 292(1), 76-87.

Marenco, S., \& Weinberger, D.R. (2000). The neurodevelopmental hypothesis of schizophrenia: following a trail of evidence from cradle to grave. Dev Psychopathol, 12(3), 501-527.

Markianos, M., Hatzimanolis, J., \& Lykouras, L. (2001). Neuroendocrine serotonergic and dopaminergic responsivity in male schizophrenic patients during treatment with neuroleptics and after switch to risperidone. Psychopharmacology (Berl), 157(1), 55-59.

Martin, P., Waters, N., Carlsson, A., \& Carlsson, M.L. (1997). The apparent antipsychotic action of the 5-HT2a receptor antagonist M100907 in a mouse model of schizophrenia is counteracted by ritanserin. (Rapid communication). $J$ Neural Transm, 104(4-5), 561-564.

Martin, P., Waters, N., Schmidt, C.J., Carlsson, A., \& Carlsson, M.L. (1998). Rodent data and general hypothesis: antipsychotic action exerted through 5-Ht2A receptor antagonism is dependent on increased serotonergic tone. $J$ Neural Transm, 105(4-5), 365-396.

Matsumoto, I., Inoue, Y., Iwazaki, T., Pavey, G., \& Dean, B. (2005). 5-HT2A and muscarinic receptors in schizophrenia: a postmortem study. Neurosci Lett, 379(3), 164-168.

Matthews, P.R., \& Harrison, P.J. (2012). A morphometric, immunohistochemical, and in situ hybridization study of the dorsal raphe nucleus in major depression, bipolar disorder, schizophrenia, and suicide. $J$ Affect Disord, 137(1-3), 125-134.

Maynard, T.M., Sikich, L., Lieberman, J.A., \& LaMantia, A.S. (2001). Neural development, cell-cell signaling, and the "twohit" hypothesis of schizophrenia. Schizophr Bull, 27(3), 457-476.

McCabe, M.S., Fowler, R.C., Cadoret, R.J., \& Winokur, G. (1972). Symptom differences in schizophrenia with good and poor prognosis. Am J Psychiatry, 128(10), 1239-1243.

McGhie, A., \& Chapman, J. (1961). Disorders of attention and perception in early schizophrenia. Br J Med Psychol, 34, 103116.

McGlashan, T.H., \& Hoffman, R.E. (2000). Schizophrenia as a disorder of developmentally reduced synaptic connectivity. Arch Gen Psychiatry, 57(7), 637-648.

Meltzer, H.Y. (1991). The mechanism of action of novel antipsychotic drugs. Schizophr Bull, 17(2), 263-287.

Meltzer, H.Y. (1999). The role of serotonin in antipsychotic drug action. Neuropsychopharmacology, 21(2 Suppl), 106S$115 \mathrm{~S}$.

Meltzer, H.Y., Bastani, B., Ramirez, L., \& Matsubara, S. (1989). Clozapine: new research on efficacy and mechanism of action. Eur Arch Psychiatry Neurol Sci, 238(5-6), 332-339.

Meltzer, H.Y., Li, Z., Kaneda, Y., \& Ichikawa, J. (2003). Serotonin receptors: their key role in drugs to treat schizophrenia. Prog Neuropsychopharmacol Biol Psychiatry, 27(7), 1159-1172.

Meltzer, H.Y., \& McGurk, S.R. (1999). The effects of clozapine, risperidone, and olanzapine on cognitive function in schizophrenia. Schizophr Bull, 25(2), 233-255.

Meltzer, H.Y., \& Stahl, S.M. (1976). The dopamine hypothesis of schizophrenia: a review. Schizophr Bull, 2(1), 19-76.

Mikuni, M., \& Meltzer, H.Y. (1984). Reduction of serotonin-2 receptors in rat cerebral cortex after subchronic administration of imipramine, chlorpromazine, and the combination thereof. Life Sci, 34(1), 87-92.

Millan, M.J., Dekeyne, A., \& Gobert, A. (1998). Serotonin (5-HT)2C receptors tonically inhibit dopamine (DA) and noradrenaline (NA), but not 5-HT, release in the frontal cortex in vivo. Neuropharmacology, 37(7), 953-955.

Mirnics, K., Middleton, F.A., Lewis, D.A., \& Levitt, P. (2001). Analysis of complex brain disorders with gene expression microarrays: schizophrenia as a disease of the synapse. Trends Neurosci, 24(8), 479-486.

Mita, T., Hanada, S., Nishino, N., Kuno, T., Nakai, H., Yamadori, T., et al. (1986). Decreased serotonin S2 and increased dopamine D2 receptors in chronic schizophrenics. Biol Psychiatry, 21(14), 1407-1414.

Miyamoto, S., LaMantia, A.S., Duncan, G.E., Sullivan, P., Gilmore, J.H., \& Lieberman, J.A. (2003). Recent advances in the neurobiology of schizophrenia. Mol Interv, 3(1), 27-39.

Moghaddam, B., Adams, B., Verma, A., \& Daly, D. (1997). Activation of glutamatergic neurotransmission by ketamine: a novel step in the pathway from NMDA receptor blockade to dopaminergic and cognitive disruptions associated with the prefrontal cortex. J Neurosci, 17(8), 2921-2927.

Moghaddam, B., \& Adams, B.W. (1998). Reversal of phencyclidine effects by a group II metabotropic glutamate receptor agonist in rats. Science, 281(5381), 1349-1352.

Mohr, P., Horacek, J., Motlova, L., Libiger, J., \& Czobor, P. (1998). Prolactin response to D-fenfluramine challenge test as a predictor of treatment response to haloperidol in acute schizophrenia. Schizophr Res, 30(1), 91-99.

Moller, H.J., Muller, H., Borison, R.L., Schooler, N.R., \& Chouinard, G. (1995). A path-analytical approach to differentiate between direct and indirect drug effects on negative symptoms in schizophrenic patients. A re-evaluation of the North American risperidone study. Eur Arch Psychiatry Clin Neurosci, 245(1), 45-49.

Monteleone, P., Tortorella, A., Borriello, R., Cassandro, P., \& Maj, M. (1999). Prolactin hyperresponsiveness to Dfenfluramine in drug-free schizophrenic patients: a placebo-controlled study. Biol Psychiatry, 45(12), 1606-1611.

Moreno, J.L., Miranda-Azpiazu, P., Garcia-Bea, A., Younkin, J., Cui, M., Kozlenkov, A., et al. (2016). Allosteric signaling through an mGlu2 and 5-HT2A heteromeric receptor complex and its potential contribution to schizophrenia. Sci Signal, 9(410), ra5.

Morey, R.A., Inan, S., Mitchell, T.V., Perkins, D.O., Lieberman, J.A., \& Belger, A. (2005). Imaging frontostriatal function in ultra-high-risk, early, and chronic schizophrenia during executive processing. Arch Gen Psychiatry, 62(3), 254-262.

Murphy, D.L., Mueller, E.A., Garrick, N.A., \& Aulakh, C.S. (1986). Use of serotonergic agents in the clinical assessment of central serotonin function. J Clin Psychiatry, 47 Suppl, 9-15. 
Murray, R.M., O'Callaghan, E., Castle, D.J., \& Lewis, S.W. (1992). A neurodevelopmental approach to the classification of schizophrenia. Schizophr Bull, 18(2), 319-332.

Muschamp, J.W., Regina, M.J., Hull, E.M., Winter, J.C., \& Rabin, R.A. (2004). Lysergic acid diethylamide and [-]-2,5dimethoxy-4-methylamphetamine increase extracellular glutamate in rat prefrontal cortex. Brain Res, 1023(1), 134140.

Naylor, L., Dean, B., Opeskin, K., Pavey, G., Hill, C., Keks, N., et al. (1996). Changes in the serotonin transporter in the hippocampus of subjects with schizophrenia identified using [3H]paroxetine. J Neural Transm, 103(6), 749-757.

Neumeyer, J.L., Wang, S.Y., Milius, R.A., Baldwin, R.M., Zea-Ponce, Y., Hoffer, P.B., et al. (1991). [123I]-2 betacarbomethoxy-3 beta-(4-iodophenyl)tropane: high-affinity SPECT radiotracer of monoamine reuptake sites in brain. J Med Chem, 34(10), 3144-3146.

Newcomer, J.W., Faustman, W.O., Zipursky, R.B., \& Csernansky, J.G. (1992). Zacopride in schizophrenia: a single-blind serotonin type 3 antagonist trial. Arch Gen Psychiatry, 49(9), 751-752.

Newman-Tancredi, A., Gavaudan, S., Conte, C., Chaput, C., Touzard, M., Verriele, L., et al. (1998). Agonist and antagonist actions of antipsychotic agents at 5-HT1A receptors: a [35S]GTPgammaS binding study. Eur J Pharmacol, 355(23), 245-256

Ng, M.Y., Levinson, D.F., Faraone, S.V., Suarez, B.K., DeLisi, L.E., Arinami, T., et al. (2009). Meta-analysis of 32 genomewide linkage studies of schizophrenia. Mol Psychiatry, 14(8), 774-785.

Ngan, E.T., Yatham, L.N., Ruth, T.J., \& Liddle, P.F. (2000). Decreased serotonin 2A receptor densities in neuroleptic-naive patients with schizophrenia: A PET study using [(18)F]setoperone. Am J Psychiatry, 157(6), 1016-1018.

Nichols, D.E. (2004). Hallucinogens. Pharmacol Ther, 101(2), 131-181.

Nichols, D.E. (2016). Psychedelics. Pharmacol Rev, 68(2), 264-355.

Nordstrom, A.L., Farde, L., Wiesel, F.A., Forslund, K., Pauli, S., Halldin, C., et al. (1993). Central D2-dopamine receptor occupancy in relation to antipsychotic drug effects: a double-blind PET study of schizophrenic patients. Biol Psychiatry, 33(4), 227-235.

Nudmamud, S., Reynolds, L.M., \& Reynolds, G.P. (2003). N-acetylaspartate and N-Acetylaspartylglutamate deficits in superior temporal cortex in schizophrenia and bipolar disorder: a postmortem study. Biol Psychiatry, 53(12), 11381141.

Nyback, H., Berggren, B.M., Hindmarsh, T., Sedvall, G., \& Wiesel, F.A. (1983). Cerebroventricular size and cerebrospinal fluid monoamine metabolites in schizophrenic patients and healthy volunteers. Psychiatry Res, 9(4), 301-308.

Nyberg, S., Eriksson, B., Oxenstierna, G., Halldin, C., \& Farde, L. (1999). Suggested minimal effective dose of risperidone based on PET-measured D2 and 5-HT2A receptor occupancy in schizophrenic patients. Am J Psychiatry, 156(6), 869-875.

O'Dell, S.J., La Hoste, G.J., Widmark, C.B., Shapiro, R.M., Potkin, S.G., \& Marshall, J.F. (1990). Chronic treatment with clozapine or haloperidol differentially regulates dopamine and serotonin receptors in rat brain. Synapse, 6(2), 146153.

Ohuoha, D.C., Hyde, T.M., \& Kleinman, J.E. (1993). The role of serotonin in schizophrenia: an overview of the nomenclature, distribution and alterations of serotonin receptors in the central nervous system. Psychopharmacology (Berl), 112 (1 Suppl), S5-15.

Okubo, Y., Suhara, T., Suzuki, K., Kobayashi, K., Inoue, O., Terasaki, O., et al. (2000). Serotonin 5-HT2 receptors in schizophrenic patients studied by positron emission tomography. Life Sci, 66(25), 2455-2464.

Osimo, E.F., Beck, K., Reis Marques, T., \& Howes, O.D. (2018). Synaptic loss in schizophrenia: a meta-analysis and systematic review of synaptic protein and mRNA measures. Mol Psychiatry.

Osmond, H., \& Smythies, J. (1952). Schizophrenia: a new approach. J Ment Sci, 98(411), 309-315.

Ostrowitzki, S., Rao, M.L., Redei, J., \& Andres, A.H. (1993). Concurrence of cortex and platelet serotonin2 receptor binding characteristics in the individual and the putative regulation by serotonin. J Neural Transm Gen Sect, 93(1), 27-35.

Owen, F., Cross, A.J., Crow, T.J., Lofthouse, R., \& Poulter, M. (1981). Neurotransmitter receptors in brain in schizophrenia. Acta Psychiatr Scand Suppl, 291, 20-28.

Owen, R.R., Jr., Gutierrez-Esteinou, R., Hsiao, J., Hadd, K., Benkelfat, C., Lawlor, B.A., et al. (1993). Effects of clozapine and fluphenazine treatment on responses to m-chlorophenylpiperazine infusions in schizophrenia. Arch Gen Psychiatry, 50(8), 636-644.

Padin, J.F., Rodriguez, M.A., Dominguez, E., Dopeso-Reyes, I.G., Buceta, M., Cano, E., et al. (2006). Parallel regulation by olanzapine of the patterns of expression of 5-HT2A and D3 receptors in rat central nervous system and blood cells. Neuropharmacology, 51(4), 923-932.

Palacios, J.M., Pazos, A., \& Hoyer, D. (2017). A short history of the 5-HT2C receptor: from the choroid plexus to depression, obesity and addiction treatment. Psychopharmacology, 234(9-10), 1395-1418.

Pardiñas, A.F., Holmans, P., Pocklington, A.J., Escott-Price, V., Ripke, S., Carrera, N., et al. (2018). Common schizophrenia alleles are enriched in mutation-intolerant genes and in regions under strong background selection. Nature Genetics, 50(3), 381-389.

Parwani, A., Duncan, E.J., Bartlett, E., Madonick, S.H., Efferen, T.R., Rajan, R., et al. (2000). Impaired prepulse inhibition of acoustic startle in schizophrenia. Biol Psychiatry, 47(7), 662-669.

Pickar, D., Owen, R.R., Litman, R.E., Konicki, E., Gutierrez, R., \& Rapaport, M.H. (1992). Clinical and biologic response to clozapine in patients with schizophrenia. Crossover comparison with fluphenazine. Arch Gen Psychiatry, 49(5), 345-353.

Pickar, D., Roy, A., Breier, A., Doran, A., Wolkowitz, O., Colison, J., et al. (1986). Suicide and aggression in schizophrenia. Neurobiologic correlates. Ann N Y Acad Sci, 487, 189-196.

Potkin, S.G., Weinberger, D.R., Linnoila, M., \& Wyatt, R.J. (1983). Low CSF 5-hydroxyindoleacetic acid in schizophrenic patients with enlarged cerebral ventricles. Am J Psychiatry, 140(1), 21-25.

Powell, S.B., \& Geyer, M.A. (2007). Overview of animal models of schizophrenia. Curr Protoc Neurosci, Chapter 9, Unit 9 24. 
Pralong, D., Tomaskovic-Crook, E., Opeskin, K., Copolov, D., \& Dean, B. (2000). Serotonin(2A) receptors are reduced in the planum temporale from subjects with schizophrenia. Schizophr Res, 44(1), 35-45.

Purdon, S.E., Jones, B.D., Stip, E., Labelle, A., Addington, D., David, S.R., et al. (2000). Neuropsychological change in early phase schizophrenia during 12 months of treatment with olanzapine, risperidone, or haloperidol. The Canadian Collaborative Group for research in schizophrenia. Arch Gen Psychiatry, 57(3), 249-258.

Quednow, B.B., Ejebe, K., Wagner, M., Giakoumaki, S.G., Bitsios, P., Kumari, V., et al. (2018). Meta-analysis on the association between genetic polymorphisms and prepulse inhibition of the acoustic startle response. Schizophrenia Research, 198, 52-59.

Quednow, B.B., Frommann, I., Berning, J., Kuhn, K.U., Maier, W., \& Wagner, M. (2008a). Impaired sensorimotor gating of the acoustic startle response in the prodrome of schizophrenia. Biol Psychiatry, 64(9), 766-773.

Quednow, B.B., Kometer, M., Geyer, M.A., \& Vollenweider, F.X. (2012). Psilocybin-induced deficits in automatic and controlled inhibition are attenuated by ketanserin in healthy human volunteers. Neuropsychopharmacology, 37(3), 630-640.

Quednow, B.B., Kuhn, K.U., Mossner, R., Schwab, S.G., Schuhmacher, A., Maier, W., et al. (2008b). Sensorimotor gating of schizophrenia patients is influenced by 5-HT2A receptor polymorphisms. Biol Psychiatry, 64(5), 434-437.

Quednow, B.B., Schmechtig, A., Ettinger, U., Petrovsky, N., Collier, D.A., Vollenweider, F.X., et al. (2009). Sensorimotor gating depends on polymorphisms of the serotonin-2A receptor and catechol-O-methyltransferase, but not on neuregulin-1 Arg38Gln genotype: a replication study. Biol Psychiatry, 66(6), 614-620.

Quednow, B.B., Wagner, M., Westheide, J., Beckmann, K., Bliesener, N., Maier, W., et al. (2006). Sensorimotor gating and habituation of the startle response in schizophrenic patients randomly treated with amisulpride or olanzapine. Biol Psychiatry, 59(6), 536-545.

Quiedeville, A., Boulouard, M., Hamidouche, K., Da Silva Costa-Aze, V., Nee, G., Rochais, C., et al. (2015). Chronic activation of 5-HT4 receptors or blockade of 5-HT6 receptors improve memory performances. Behav Brain Res, $293,10-17$.

Rahman, S., \& Neuman, R.S. (1993). Activation of 5-HT2 receptors facilitates depolarization of neocortical neurons by Nmethyl-D-aspartate. Eur J Pharmacol, 231(3), 347-354.

Rapport, M.M. (1949). Serum vasoconstrictor (serotonin) the presence of creatinine in the complex; a proposed structure of the vasoconstrictor principle. $J$ Biol Chem, 180(3), 961-969.

Rapport, M.M., Green, A.A., \& Page, I.H. (1948). Serum vasoconstrictor, serotonin; isolation and characterization. J Biol Chem, 176(3), 1243-1251.

Rasmussen, H., Erritzoe, D., Andersen, R., Ebdrup, B.H., Aggernaes, B., Oranje, B., et al. (2010). Decreased frontal serotonin2A receptor binding in antipsychotic-naive patients with first-episode schizophrenia. Arch Gen Psychiatry, 67(1), 9-16.

Rasmussen, H., Frokjaer, V.G., Hilker, R.W., Madsen, J., Anhoj, S., Oranje, B., et al. (2016). Low frontal serotonin 2A receptor binding is a state marker for schizophrenia? Eur Neuropsychopharmacol, 26(7), 1248-1250.

Renyi, L., Evenden, J.L., Fowler, C.J., Jerning, E., Kelder, D., Lake-Bakaar, D., et al. (2001). The pharmacological profile of (R)-3,4-dihydro-N-isopropyl-3-(N-isopropyl-N-propylamino)-2H-1-benzopyran- 5-carboxamide, a selective 5hydroxytryptamine(1A) receptor agonist. J Pharmacol Exp Ther, 299(3), 883-893.

Reynolds, G.P., Beasley, C.L., \& Zhang, Z.J. (2002). Understanding the neurotransmitter pathology of schizophrenia: selective deficits of subtypes of cortical GABAergic neurons. J Neural Transm, 109(5-6), 881-889.

Reynolds, G.P., Garrett, N.J., Rupniak, N., Jenner, P., \& Marsden, C.D. (1983a). Chronic clozapine treatment of rats downregulates cortical 5-HT2 receptors. Eur J Pharmacol, 89(3-4), 325-326.

Reynolds, G.P., Rossor, M.N., \& Iversen, L.L. (1983b). Preliminary studies of human cortical 5-HT2 receptors and their involvement in schizophrenia and neuroleptic drug action. J Neural Transm Suppl, 18, 273-277.

Rickli, A., Luethi, D., Reinisch, J., Buchy, D., Hoener, M.C., \& Liechti, M.E. (2015). Receptor interaction profiles of novel $\mathrm{N}$-2-methoxybenzyl (NBOMe) derivatives of 2,5-dimethoxy-substituted phenethylamines (2C drugs). Neuropharmacology, 99, 546-553.

Rinkel, M., De, S.H., Hyde, R.W., \& Solomon, H.C. (1952). Experimental schizophrenia-like symptoms. Am J Psychiatry, 108(8), 572-578.

Rinkel, M., Hyde, R.W., Solomon, H.C., \& Hoagland, H. (1955). Experimental psychiatry. II. Clinical and physio-chemical observations in experimental psychosis. Am J Psychiatry, 111(12), 881-895.

Ripke, S. (2014). Biological insights from 108 schizophrenia-associated genetic loci. Nature, 511(7510), 421-427.

Risch, S.C. (1995). Clozapine therapy and increases in homovanillic acid. Arch Gen Psychiatry, 52(3), 244.

Risch, S.C., \& Lewine, R.R. (1993). Low cerebrospinal fluid homovanillic acid-5-hydroxyindoleacetic acid ratio predicts clozapine efficacy: a replication. Arch Gen Psychiatry, 50(8), 670.

Rollema, H., Lu, Y., Schmidt, A.W., \& Zorn, S.H. (1997). Clozapine increases dopamine release in prefrontal cortex by 5HT1A receptor activation. Eur J Pharmacol, 338(2), R3-5.

Roth, B., \& Meltzer, H.Y. (2000). The role of serotonin in schizophrenia. In F.E. Bloom \& D.J. Kupfer (Eds.), Psychopharmacology: The Fourth Generation of Progress (pp. 1215-1228). Nashville TN: American College of Neuropsychopharmacology.

Roth, B.L., Ciaranello, R.D., \& Meltzer, H.Y. (1992). Binding of typical and atypical antipsychotic agents to transiently expressed 5-HT1C receptors. J Pharmacol Exp Ther, 260(3), 1361-1365.

Roth, B.L., Craigo, S.C., Choudhary, M.S., Uluer, A., Monsma, F.J., Jr., Shen, Y., et al. (1994). Binding of typical and atypical antipsychotic agents to 5-hydroxytryptamine-6 and 5-hydroxytryptamine-7 receptors. J Pharmacol Exp Ther, 268(3), 1403-1410.

Roth, B.L., Hanizavareh, S.M., \& Blum, A.E. (2004). Serotonin receptors represent highly favorable molecular targets for cognitive enhancement in schizophrenia and other disorders. Psychopharmacology (Berl), 174(1), 17-24.

Scarr, E., Pavey, G., Copolov, D., \& Dean, B. (2004). Hippocampal 5-hydroxytryptamine receptors: abnormalities in postmortem brain from schizophrenic subjects. Schizophr Res, 71(2-3), 383-392. 
Scheepers, F.E., Gespen de Wied, C.C., \& Kahn, R.S. (2001a). The effect of olanzapine treatment on mchlorophenylpiperazine-induced hormone release in schizophrenia. J Clin Psychopharmacol, 21(6), 575-582.

Scheepers, F.E., Gispen-de Wied, C.C., Westenberg, H.G., \& Kahn, R.S. (2001b). The effect of olanzapine treatment on monoamine metabolite concentrations in the cerebrospinal fluid of schizophrenic patients. Neuropsychopharmacology, 25(4), 468-475.

Schulz, E., Fleischhaker, C., Clement, H.W., \& Remschmidt, H. (1997). Blood biogenic amines during clozapine treatment of early-onset schizophrenia. J Neural Transm, 104(10), 1077-1089.

Scruggs, J.L., Schmidt, D., \& Deutch, A.Y. (2003). The hallucinogen 1-[2,5-dimethoxy-4-iodophenyl]-2-aminopropane (DOI) increases cortical extracellular glutamate levels in rats. Neurosci Lett, 346(3), 137-140.

Seeman, P. (1987). Dopamine receptors and the dopamine hypothesis of schizophrenia. Synapse, 1(2), 133-152.

Seeman, P. (2002). Atypical antipsychotics: mechanism of action. Can J Psychiatry, 47(1), 27-38.

Seeman, P., Guan, H.C., \& Van Tol, H.H. (1993). Dopamine D4 receptors elevated in schizophrenia. Nature, 365(6445), 441-445.

Seeman, P., Lee, T., Chau-Wong, M., \& Wong, K. (1976). Antipsychotic drug doses and neuroleptic/dopamine receptors. Nature, 261(5562), 717-719.

Segal, D.S., Geyer, M.A., \& Schuckit, M.A. (1981). Stimulant-induced psychosis: An evaluation of animal models. In M.B.H. Youdim, W. Lovenberg, D.F. Sharman, \& J.R. Lagnado (Eds.), Essays in Neurochemistry and Neuropharmacology (Vol. 5, pp. 95-130). New York: John Wiley \& Sons.

Selvaraj, S., Arnone, D., Cappai, A., \& Howes, O. (2014). Alterations in the serotonin system in schizophrenia: a systematic review and meta-analysis of postmortem and molecular imaging studies. Neurosci Biobehav Rev, 45, 233-245.

Shapiro, D.A., Renock, S., Arrington, E., Chiodo, L.A., Liu, L.X., Sibley, D.R., et al. (2003). Aripiprazole, a novel atypical antipsychotic drug with a unique and robust pharmacology. Neuropsychopharmacology, 28(8), 1400-1411.

Sharma, R.P., Singh, V., Janicak, P.G., Javaid, J.I., \& Pandey, G.N. (1999). The prolactin response to fenfluramine in schizophrenia is associated with negative symptoms. Schizophr Res, 39(1), 85-89.

Shen, J.H.Q., Zhao, Y., Rosenzweig-Lipson, S., Popp, D., Williams, J.B.W., Giller, E., et al. (2014). A 6-week randomized, double-blind, placebo-controlled, comparator referenced trial of vabicaserin in acute schizophrenia. Journal of Psychiatric Research, 53, 14-22.

Snyder, S.H. (1973). Amphetamine psychosis: a "model" schizophrenia mediated by catecholamines. Am J Psychiatry, 130(1), 61-67.

Sodhi, M.S., \& Sanders-Bush, E. (2004). Serotonin and brain development. Int Rev Neurobiol, 59, 111-174.

Stoll, W.A. (1947). Lysergsäure-diäthylamid, ein Phantastikum aus der Mutterkorngruppe. Schweiz Arch Neurol Psychiatr, 60, 279-323.

Stoll, W.A. (1949). Ein neues, in sehr kleinen Mengen wirksames Phantastikum. Schweiz Arch Neurol Psychiatr, 64, 483484.

Strassman, R.J. (1995). Hallucinogenic drugs in psychiatric research and treatment. Perspectives and prospects. J Nerv Ment Dis, 183(3), 127-138.

Strassman, R.J., Qualls, C.R., Uhlenhuth, E.H., \& Kellner, R. (1994). Dose-response study of N,N-dimethyltryptamine in humans. II. Subjective effects and preliminary results of a new rating scale. Arch Gen Psychiatry, 51(2), 98-108.

Sumiyoshi, T., Matsui, M., Nohara, S., Yamashita, I., Kurachi, M., Sumiyoshi, C., et al. (2001a). Enhancement of cognitive performance in schizophrenia by addition of tandospirone to neuroleptic treatment. Am J Psychiatry, 158(10), $1722-1725$.

Sumiyoshi, T., Matsui, M., Yamashita, I., Nohara, S., Kurachi, M., Uehara, T., et al. (2001b). The effect of tandospirone, a serotonin(1A) agonist, on memory function in schizophrenia. Biol Psychiatry, 49(10), 861-868.

Sumiyoshi, T., Park, S., Jayathilake, K., Roy, A., Ertugrul, A., \& Meltzer, H.Y. (2007). Effect of buspirone, a serotonin1A partial agonist, on cognitive function in schizophrenia: a randomized, double-blind, placebo-controlled study. Schizophr Res, 95(1-3), 158-168.

Sumiyoshi, T., Stockmeier, C.A., Overholser, J.C., Dilley, G.E., \& Meltzer, H.Y. (1996). Serotonin1A receptors are increased in postmortem prefrontal cortex in schizophrenia. Brain Res, 708(1-2), 209-214.

Swerdlow, N.R., \& Geyer, M.A. (1998). Using an animal model of deficient sensorimotor gating to study the pathophysiology and new treatments of schizophrenia. Schizophr Bull, 24(2), 285-301.

Swerdlow, N.R., Geyer, M.A., \& Braff, D.L. (2001). Neural circuit regulation of prepulse inhibition of startle in the rat: current knowledge and future challenges. Psychopharmacology (Berl), 156(2-3), 194-215.

Szymanski, S., Lieberman, J., Pollack, S., Munne, R., Safferman, A., Kane, J., et al. (1993). The dopamine-serotonin relationship in clozapine response. Psychopharmacology (Berl), 112(1 Suppl), S85-89.

Tamminga, C.A., \& Holcomb, H.H. (2005). Phenotype of schizophrenia: a review and formulation. Mol Psychiatry, 10(1), 27-39.

Tauscher, J., Kapur, S., Verhoeff, N.P., Hussey, D.F., Daskalakis, Z.J., Tauscher-Wisniewski, S., et al. (2002). Brain serotonin 5-HT(1A) receptor binding in schizophrenia measured by positron emission tomography and [11C]WAY-100635. Arch Gen Psychiatry, 59(6), 514-520.

Tilson, H.A., Baker, T.G., \& Chamberlain, J.H. (1975). Behavioral and neuropharmacological analysis of amphetamine and 2,5-dimethoxy-4-methylamphetamine in rats. Psychopharmacologia, 44(3), 229-239.

Tollefson, G.D., \& Sanger, T.M. (1997). Negative symptoms: a path analytic approach to a double-blind, placebo- and haloperidol-controlled clinical trial with olanzapine. Am J Psychiatry, 154(4), 466-474.

Trichard, C., Paillere-Martinot, M.L., Attar-Levy, D., Blin, J., Feline, A., \& Martinot, J.L. (1998). No serotonin 5-HT2A receptor density abnormality in the cortex of schizophrenic patients studied with PET. Schizophr Res, 31(1), 13-17.

Tuckwell, H.C., \& Koziol, J.A. (1993). A meta-analysis of homovanillic acid concentrations in schizophrenia. Int J Neurosci, 73(1-2), 109-114.

Tuckwell, H.C., \& Koziol, J.A. (1996). On the concentration of 5-hydroxyindoleacetic acid in schizophrenia: a meta-analysis. Psychiatry Res, 59(3), 239-244. 
Twarog, B.M., \& Page, I.H. (1953). Serotonin content of some mammalian tissues and urine and a method for its determination. Am J Physiol, 175(1), 157-161.

van der Heijden, F.M., Tuinier, S., Fekkes, D., Sijben, A.E., Kahn, R.S., \& Verhoeven, W.M. (2004). Atypical antipsychotics and the relevance of glutamate and serotonin. Eur Neuropsychopharmacol, 14(3), 259-265.

van Kammen, D.P., Peters, J., \& van Kammen, W.B. (1986). Cerebrospinal fluid studies of monoamine metabolism in schizophrenia. Psychiatr Clin North Am, 9(1), 81-97.

van Rossum, J.M. (1966). The significance of dopamine-receptor blockade for the mechanism of action of neuroleptic drugs. Arch Int Pharmacodyn Ther, 160(2), 492-494.

Varty, G.B., Bakshi, V.P., \& Geyer, M.A. (1999). M100907, a serotonin 5-HT2A receptor antagonist and putative antipsychotic, blocks dizocilpine-induced prepulse inhibition deficits in Sprague-Dawley and Wistar rats. Neuropsychopharmacology, 20(4), 311-321.

Verhoeff, N.P., Meyer, J.H., Kecojevic, A., Hussey, D., Lewis, R., Tauscher, J., et al. (2000). A voxel-by-voxel analysis of $[18 \mathrm{~F}]$ setoperone PET data shows no substantial serotonin 5-HT(2A) receptor changes in schizophrenia. Psychiatry Res, 99(3), 123-135.

Vollenweider, F.X., Csomor, P.A., Knappe, B., Geyer, M.A., \& Quednow, B.B. (2007). The effects of the preferential 5HT2A agonist psilocybin on prepulse inhibition of startle in healthy human volunteers depend on interstimulus interval. Neuropsychopharmacology, 32(9), 1876-1887.

Vollenweider, F.X., \& Geyer, M.A. (2001). A systems model of altered consciousness: integrating natural and drug-induced psychoses. Brain Res Bull, 56(5), 495-507.

Vollenweider, F.X., Leenders, K.L., Scharfetter, C., Antonini, A., Maguire, P., Missimer, J., et al. (1997a). Metabolic hyperfrontality and psychopathology in the ketamine model of psychosis using positron emission tomography (PET) and [18F] fluorodeoxyglucose (FDG). Eur Neuropsychopharmacol, 7(1), 9-24.

Vollenweider, F.X., Leenders, K.L., Scharfetter, C., Maguire, P., Stadelmann, O., \& Angst, J. (1997b). Positron emission tomography and fluorodeoxyglucose studies of metabolic hyperfrontality and psychopathology in the psilocybin model of psychosis. Neuropsychopharmacology, 16(5), 357-372.

Vollenweider, F.X., Vollenweider-Scherpenhuyzen, M.F., Babler, A., Vogel, H., \& Hell, D. (1998). Psilocybin induces schizophrenia-like psychosis in humans via a serotonin-2 agonist action. Neuroreport, 9(17), 3897-3902.

Wagner, M., Quednow, B.B., Westheide, J., Schlaepfer, T.E., Maier, W., \& Kuhn, K.U. (2005). Cognitive improvement in schizophrenic patients does not require a serotonergic mechanism: randomized controlled trial of olanzapine vs amisulpride. Neuropsychopharmacology, 30(2), 381-390.

Weinberger, D.R., Berman, K.F., \& Illowsky, B.P. (1988). Physiological dysfunction of dorsolateral prefrontal cortex in schizophrenia. III. A new cohort and evidence for a monoaminergic mechanism. Arch Gen Psychiatry, 45(7), 609615.

Weinberger, D.R., Berman, K.F., Suddath, R., \& Torrey, E.F. (1992). Evidence of dysfunction of a prefrontal-limbic network in schizophrenia: a magnetic resonance imaging and regional cerebral blood flow study of discordant monozygotic twins. Am J Psychiatry, 149(7), 890-897.

Weinberger, R.D., \& Laruelle, M. (2002). Neurochemical and neuropharmacological imaging in schizophrenia. In K.L. Davis, D.S. Charney, J.T. Coyle, \& C.B. Nemeroff (Eds.), Neuropsychopharmacology: The Fifth Generation of Progress (pp. 833-855). Philadelphia: Lippincott, Williams \& Wilkins.

Weinstein, J.J., Chohan, M.O., Slifstein, M., Kegeles, L.S., Moore, H., \& Abi-Dargham, A. (2017). Pathway-Specific Dopamine Abnormalities in Schizophrenia. Biol Psychiatry, 81(1), 31-42.

Whitaker, P.M., Crow, T.J., \& Ferrier, I.N. (1981). Tritiated LSD binding in frontal cortex in schizophrenia. Arch Gen Psychiatry, 38(3), 278-280.

Wieselgren, I.M., \& Lindstrom, L.H. (1998). CSF levels of HVA and 5-HIAA in drug-free schizophrenic patients and healthy controls: a prospective study focused on their predictive value for outcome in schizophrenia. Psychiatry Res, 81(2), 101-110.

Wilmot, C.A., \& Szczepanik, A.M. (1989). Effects of acute and chronic treatments with clozapine and haloperidol on serotonin (5-HT2) and dopamine (D2) receptors in the rat brain. Brain Res, 487(2), 288-298.

Winblad, B., Bucht, G., Gottfries, C.G., \& Roos, B.E. (1979). Monoamines and monoamine metabolites in brains from demented schizophrenics. Acta Psychiatr Scand, 60(1), 17-28.

Winter, J.C., Doat, M., \& Rabin, R.A. (2000). Potentiation of DOM-induced stimulus control by non-competitive NMDA antagonists: a link between the glutamatergic and serotonergic hypotheses of schizophrenia. Life Sci, 68(3), 337344.

Winter, J.C., Eckler, J.R., \& Rabin, R.A. (2004). Serotonergic/glutamatergic interactions: the effects of mGlu2/3 receptor ligands in rats trained with LSD and PCP as discriminative stimuli. Psychopharmacology (Berl), 172(2), 233-240.

Wong, D.F., Wagner, H.N., Jr., Tune, L.E., Dannals, R.F., Pearlson, G.D., Links, J.M., et al. (1986). Positron emission tomography reveals elevated D2 dopamine receptors in drug-naive schizophrenics. Science, 234(4783), 1558-1563.

Wood, S.J., Berger, G., Velakoulis, D., Phillips, L.J., McGorry, P.D., Yung, A.R., et al. (2003). Proton magnetic resonance spectroscopy in first episode psychosis and ultra high-risk individuals. Schizophr Bull, 29(4), 831-843.

Woods, S., Clarke, N.N., Layfield, R., \& Fone, K.C. (2012). 5-HT(6) receptor agonists and antagonists enhance learning and memory in a conditioned emotion response paradigm by modulation of cholinergic and glutamatergic mechanisms. Br J Pharmacol, 167(2), 436-449.

Woolley, D.W. (1962). The Biochemical Bases of Psychosis or the Serotonin Hypothesis about Mental Disease. New York: John Wiley \& Sons.

Woolley, D.W., \& Shaw, E. (1953). Antimetabolites of serotonin. J Biol Chem, 203(1), 69-79.

Woolley, D.W., \& Shaw, E. (1954). Some neurophysiological aspects of serotonin. Br Med J, 2(4880), 122-126.

Yasuno, F., Suhara, T., Ichimiya, T., Takano, A., Ando, T., \& Okubo, Y. (2004). Decreased 5-HT1A receptor binding in amygdala of schizophrenia. Biol Psychiatry, 55(5), 439-444. 
Yasuno, F., Suhara, T., Nakayama, T., Ichimiya, T., Okubo, Y., Takano, A., et al. (2003). Inhibitory effect of hippocampal 5HT1A receptors on human explicit memory. Am J Psychiatry, 160(2), 334-340.

Zhang, C., \& Marek, G.J. (2008). AMPA receptor involvement in 5-hydroxytryptamine2A receptor-mediated pre-frontal cortical excitatory synaptic currents and DOI-induced head shakes. Prog Neuropsychopharmacol Biol Psychiatry, 32(1), 62-71.

Zhang, J.P., Lencz, T., Zhang, R.X., Nitta, M., Maayan, L., John, M., et al. (2016). Pharmacogenetic Associations of Antipsychotic Drug-Related Weight Gain: A Systematic Review and Meta-analysis. Schizophr Bull, 42(6), 14181437.

Zipursky, R.B., Meyer, J.H., \& Verhoeff, N.P. (2007). PET and SPECT imaging in psychiatric disorders. Can J Psychiatry, 52(3), 146-157.

Zureick, J.L., \& Meltzer, H.Y. (1988). Platelet MAO activity in hallucinating and paranoid schizophrenics: a review and meta-analysis. Biol Psychiatry, 24(1), 63-78. 